\title{
Bryozoan fauna from the Kunda Stage (Darriwilian, Middle Ordovician) of Estonia and NW Russia
}

\author{
AndReJ ERnst
}

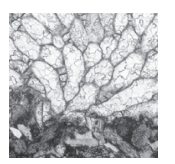

\begin{abstract}
Bryozoan fauna from several outcrops of sediments of the Kunda Stage (Darriwilian, Middle Ordovician) of Estonia and NW Russia contains 18 species which belong to the palaeostomate orders Cystoporata, Esthonioporata, Trepostomata, and Cryptostomata. The studied material comes mainly from the collection of the Department of Geology, Tallinn University of Technology, as well as was specimens I have collected. One genus with one species and one more species are new: Pakripora cavernosa gen. et sp. nov. and Dianulites pakriensis sp. nov. Four bryozoans are identified to genus level only. One cryptostome bryozoan shows unique morphology unknown in any similar genera. In general, the studied fauna shows close relations to other localities within the Baltic region, with some few relations to the Ordovician of China. The bryozoans developed massive and erect colonies, showing adaptation to the shallow to moderately deep environment with moderate water energy and relatively high level of sedimentation. - Key words: Ordovician; Darriwilian; Bryozoa; systematics; palaeogeography; palaeoecology.
\end{abstract}

ERnst, A. 2022. Bryozoan fauna from the Kunda Stage (Darriwilian, Middle Ordovician) of Estonia and NW Russia. Bulletin of Geosciences 97(1), 33-68 (18 figures, 16 tables). Czech Geological Survey, Prague. ISSN 1214-1119. Manuscript received September 30, 2021; accepted in revised form December 20, 2021; published online January 23, 2022; issued January 23, 2022.

Andrej Ernst, Institute for Geology, University of Hamburg, Bundesstr. 55, D-20146 Hamburg, Germany; Andrej. Ernst@uni-hamburg.de

Ordovician Bryozoa were one of many marine groups which evolved rapidly during the Great Ordovician Biodiversification Event (GOBI). According to the recent compilation (Ernst 2018) bryozoans experienced significant diversification in the period from the Tremadocian (Lower Ordovician) to the late Sandbian (Upper Ordovician). Bryozoan faunas of Baltoscandia played an important role in this biodiversification; however, the detailed knowledge of those faunas is patchy. Since the monumental work of Bassler (1911) no comprehensive restudy of this diverse and widely distributed group in the Baltoscandian region has been attempted. Separate bryozoan taxa were treated in various publications (e.g. Modzalevskaya 1953, 1986; Lavrentjeva 1975, 1985; Gorjunova \& Lavrentjeva 1993; Fedorov et al. 2017; Koromyslova \& Fedorov 2021).

The only exception is the unpublished dissertation made by Ralf Männil (1959) in which he summarized an immense overview of the Ordovician bryozoans of Estonia. Unfortunately, only a few of his species were subsequently published by him or others (Männil 1958; Pushkin 1987, 1990; Gorjunova \& Lavrentjeva 1993). Therefore, the majority of taxa established by Männil (1959) are invalid and still await their re-evaluation.

This paper is devoted to the study of bryozoans from several outcrops of sediments of the Kunda Stage
(Darriwilian, Middle Ordovician) of Estonian and NW Russia. Middle Ordovician bryozoans are known from various localities in Baltoscandia (e.g. Bassler 1911; Gorjunova 2005, 2009; Koromyslova 2004, 2007, 2011). Bryozoans are relatively rare fossils in the rocks of this age, therefore, the available material which has been mainly studied using oriented thin sections represents significant interest. The majority of bryozoan samples for this study derive from the collection of the Department of Geology of Tallinn University of Technology. I collected additional material in Estonia (Harku quarry) and in NW Russia (Putilovo quarry) (Fig. 1).

\section{Stratigraphy and environmental setting}

The Ordovician succession of the East Baltic is now subdivided into 18 regional stages (e.g. Kaljo \& Nestor 1990; Meidla 1997; Nõlvak et al. 2006). The Kunda regional stage represents the lower part of the Darriwilian (Middle Ordovician) overlaying the Volkhov regional stage and followed by Aseri regional stage (Fig. 2). The outcrops of the Kunda stage are quite uniform in their sedimentological characteristic and contain mainly glauconite-rich limestones (bioclastic packstones to wackestones, with varying amounts of terrigenous 


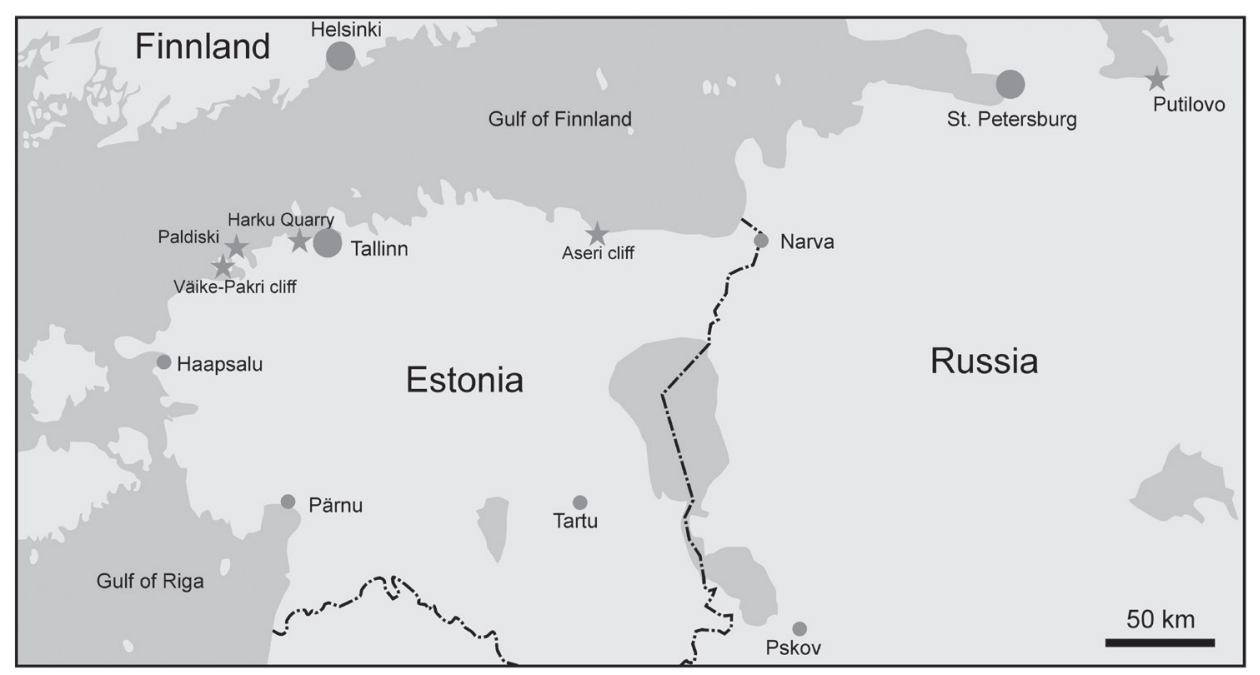

Figure 1. Map of the Baltic region showing position of studied localities (asterisks). particles) which often contain ferruginous oolites. The fauna is scarce and represented by rare bryozoans, brachiopods, crinoids, and trilobites. The depositional environment corresponds to the cool-water to temperate conditions accompanied by sea-level lowstands (e.g. Cocks \& Torsvik 2005; Dronov \& Rozhnov 2007; Hansen et al. 2011; Torsvik \& Cocks 2016).

\begin{tabular}{|c|c|c|}
\hline 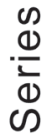 & 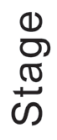 & $\begin{array}{c}\text { Regional } \\
\text { stage }\end{array}$ \\
\hline \multirow{5}{*}{$\begin{array}{l}\frac{1}{0} \\
\frac{0}{0} \\
\cdot \frac{0}{2} \\
0 \\
0 \\
0 \\
0 \\
\frac{1}{0} \\
\frac{0}{2} \\
\frac{0}{2}\end{array}$} & \multirow{4}{*}{ 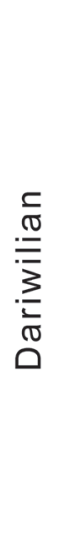 } & Uhaku \\
\hline & & Lasnamägi \\
\hline & & Aseri \\
\hline & & Kunda \\
\hline & 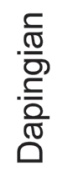 & Volkhov \\
\hline
\end{tabular}

Figure 2. Stratigraphy of the Middle Ordovician in the Baltic region (modified after Hints et al. 2008).

\section{Material and methods}

I collected material for this study and borrowed additional samples from the collection of the Department of Geology, Tallinn University of Technology. The studied samples derive from following localities (Fig. 1): Paldiski, Estonia $\left(59^{\circ} 23^{\prime} 15^{\prime \prime} \mathrm{N}, 24^{\circ} 02^{\prime} 10^{\prime \prime} \mathrm{E}\right)$; Väike-Pakri island, Estonia $\left(59^{\circ} 21^{\prime} 28^{\prime \prime} \prime \mathrm{N}, 23^{\circ} 58^{\prime} 44^{\prime \prime} \mathrm{E}\right)$; Aseri, Estonia (59 26' $50^{\prime \prime} \mathrm{N}$, $\left.26^{\circ} 51^{\prime} 48^{\prime \prime} \mathrm{E}\right)$; Harku Quarry, Estonia (59 $23^{\circ} 48^{\prime \prime} \mathrm{N}$, $\left.24^{\circ} 33^{\prime} 46^{\prime \prime} \mathrm{E}\right)$; Putilovo Quarry, Russia (59 $51^{\prime} 30^{\prime \prime} \mathrm{N}$, $\left.31^{\circ} 24^{\prime} 30^{\prime \prime} \mathrm{E}\right)$.

Normal/transverse, longitudinal, and tangential sections were prepared from the studied material. This resulted in 134 thin sections were made $(24 \times 48 \mathrm{~mm}$ and $50 \times 50 \mathrm{~mm})$. Samples and thin sections are housed in the collection of the Department of Geology, Tallinn University of Technology (index GIT). Bryozoans were investigated in thin sections using a binocular microscope in transmitted light. Morphologic character terminology is partly adopted from Anstey \& Perry (1970) and Hageman (1993).

\section{Systematic palaeontology}

Phylum Bryozoa Ehrenberg, 1831

Class Stenolaemata Borg, 1926

Superorder Palaeostomata Ma et al., 2014

Order Cystoporata Astrova, 1964

Suborder Ceramoporina Bassler, 1913

Family Ceramoporidae Ulrich, 1882

Genus Ceramopora Hall, 1851 in Silliman et al. (1851)

Type species. - C. imbricata Hall, 1852. Niagaran Group (middle Silurian); Lockport, New York, USA. 
Diagnosis. - Colonies thin discoidal expansions; encrusting, free, or in a combination. Autozooecia large, commonly rhombically arranged cavity ovate or rhomboidal in cross section, budding from the epitheca. Communication pores abundant, most commonly just distal to ends of the lunaria. Lunaria small in the inner exozone, large on the colony surface. Diaphragms absent. Exilazooecia few to abundant in intermonticular areas, generally small and subcircular in cross section, lacking diaphragms. Monticulae with depressed centres, exilazooecia of central cluster more angular then intermonticular exilazooecia.

Remarks. - The genus Ceramopora Hall, 1851 in Silliman et al. (1851) differs from the genus Ceramoporella Ulrich, 1882 by the absence of diaphragms and having more common communication pores, from the genus Acanthoceramoporella Utgaard, 1968 - by the absence of acanthostyles.

Occurrence. - Upper Ordovician-middle Silurian; North America, Europe, Siberia.

\section{Ceramopora cf. magnicellularis Männil \& Pushkin, 1990 in Pushkin (1990)}

Figure 3A-E; Table 1

1990 Ceramopora magnicellularis Männil \& Pushkin, 1990; Pushkin, p. 7, pl. 1, fig. 1.

Material. - Single specimen GIT 155-2041a-d (four thin sections).

Table 1. Descriptive statistics of Ceramopora cf. magnicellularis Männil \& Pushkin, 1990 in Pushkin (1990) (one colony measured). Abbreviations: $\mathrm{N}$ - number of measurements; $\times$ - mean; MIN - minimal value; MAX - maximal value; $\mathrm{SD}$ - sample standard deviation; $\mathrm{CV}$ coefficient of variation.

\begin{tabular}{lcccccc}
\hline & $\mathrm{N}$ & $\mathrm{MIN}$ & $\mathrm{MAX}$ & $\mathrm{X}$ & $\mathrm{SD}$ & $\mathrm{CV}$ \\
\hline Aperture width, mm & 25 & 0.30 & 0.58 & 0.43 & 0.063 & 14.53 \\
Aperture spacing, mm & 25 & 0.40 & 0.60 & 0.48 & 0.056 & 11.53 \\
Lunarium width, mm & 25 & 0.17 & 0.30 & 0.22 & 0.032 & 14.35 \\
Lunarium length, mm & 25 & 0.07 & 0.19 & 0.12 & 0.033 & 27.91 \\
Lunarium thickness, mm & 25 & 0.05 & 0.11 & 0.08 & 0.018 & 24.32 \\
Diaphragm spacing, mm & 20 & 0.25 & 0.65 & 0.44 & 0.097 & 22.15 \\
Exilazooecia width, mm & 25 & 0.06 & 0.19 & 0.12 & 0.034 & 29.28 \\
\hline
\end{tabular}

Description. - Massive colony consisting of three subcolonies, $22 \mathrm{~mm}$ thick in its central part and $32 \mathrm{~mm}$ wide at its base. Subcolonies $5-20 \mathrm{~mm}$ in height, produced by encrusting layers. Autozooecia growing from thin epitheca, bending in the early exozone to the colony surface. Epitheca $0.010-0.015 \mathrm{~mm}$ thick. Basal diaphragms abundant, straight or inclined, thin. Autozooecial apertures rounded to subpolygonal, 4.0-4.4 spaced per $1 \mathrm{~mm}^{2}$. Lunaria well-developed, rounded to slightly triangular, consisting of granular material; ends of lunaria indenting autozooecia. Exilazooecia small to large, irregularly shaped in transverse section, common to abundant, not completely separating autozooecia, arranged in 1-2 rows between apertures, 1-6 surrounding each autozooecial aperture and $4.1-4.6$ spaced per $1 \mathrm{~mm}^{2}$ of colony surface, with rounded to flat roofs, roundedpolygonal in tangential section. Autozooecial walls granular prismatic, $0.010-0.015 \mathrm{~mm}$ thick in endozone and $0.04-0.05 \mathrm{~mm}$ thick in exozone. Maculae not observed.

Remarks. - The species Ceramopora magnicellularis Männil \& Pushkin, 1990 in Pushkin (1990) was established on the base of a single holotype (GIT 537-1635) from the Aseri Stage of Ojaküla, Estonia. This sample is missing from the collection of Tallinn University of Technology (Ursula Toom, personal communication 2021). The present material has similar shape and size of autozooecial apertures with well-developed lunaria (aperture width $0.30-0.58 \mathrm{~mm} v s .0 .44-0.63 \mathrm{~mm}$ in the sample GIT 5371635). The present material has also more abundant diaphragms and exilazooecia than the holotype. Generic concept of Ceramopora (see Utgaard, 1983, pp. 358, 359) includes absence of diaphragms which are present in the genus Ceramoporella Ulrich, 1882. Pushkin (1990) mentioned diaphragms spaced $0.5-1.0 \mathrm{~mm}$ in autozooecia of Ceramopora magnicellularis. In the studied material diaphragms are spaced more closely: $0.25-0.65 \mathrm{~mm}$.

The present material differs from Ceramopora explicata Pushkin, 1976 from the Ordovician of Belarus in having larger autozooecial apertures (aperture width $0.30-0.58 \mathrm{~mm}$ vs. $0.40-0.50 \mathrm{~mm}$ in C. explicata) and in having smaller exilazooecia which can exceed the size of regular autozooecia in C. explicata.

Occurrence. - Kunda Stage, Darriwilian, Middle Ordovician; Väike-Pakri cliff, Estonia.

Order Esthonioporata Astrova, 1978

Family Dianulitidae Vinassa de Regny, 1921

\section{Genus Dianulites Eichwald, 1829}

Type species. - D. detritus $[=$ D. fastigiatus $]$ Eichwald, 1829. Lower to Middle Ordovician; Russia, Estonia.

Diagnosis. - Colony turbinate, cone or horn-shaped, sometimes compound, occasionally with a conical central cavity, in some species massive hemispherical; zooecia opening on upper, distal surface of colony; colony sides 
comprising exterior wall; not differentiated into endozone and exozone; maculae variably developed, some monticulate. Zooecia long polygonal tubes, monomorphic or obscurely polymorphic; walls thin, indistinct, granular, inclusion-rich; styles lacking; diaphragms moderately abundant, microstructural fabric strongly radial (modified after Taylor \& Wilson 1999).

Remarks. - Dianulites Eichwald, 1829 belongs to the family of its own: Dianulitidae Vinassa de Regny, 1921. It shows similarities to the unplaced genus Nicholsonella Ulrich, 1890. These genera possess re-crystallized walls which suggest a diagenetically unstable aragonitic (McKinney 1971) or high Mg calcite composition (Taylor \& Wilson 1999, Smith et al. 2006). Nicholsonella differs from Dianulites in having abundant mesozooecia and acanthostyles.

Occurrence. - Lower to Upper Ordovician; Europe, North and South America, Asia.

\section{Dianulites collucatus Pushkin, 2001 in Pushkin \& Popov (2001)}

Figure 3F, G; 4A-D; Table 2

2001 Dianulites collucatus Pushkin; Pushkin \& Popov, pp. 26, 27, pl. 3, figs $1-6$; p. 4, figs $1-6$, text-figs 3.5-3.8.

Material. - GIT 155-1527a-e, GIT 852-1a-g, GIT 8526a-d, GIT 852-21a-c, GIT 852-23a-c, GIT 852-24a-d, GIT 852-25a-d, GIT 852-26a-d (thirty-four thin sections).

Table 2. Descriptive statistics of Dianulites collucatus Pushkin, 2001 in Pushkin \& Popov (2001) (seven colonies measured). Abbreviations as for Table 1.

\begin{tabular}{lcccccc}
\hline & $\mathrm{N}$ & $\mathrm{MIN}$ & $\mathrm{MAX}$ & $\mathrm{X}$ & $\mathrm{SD}$ & $\mathrm{CV}$ \\
\hline Aperture width, mm & 150 & 0.30 & 0.51 & 0.42 & 0.046 & 10.98 \\
Aperture spacing, mm & 150 & 0.35 & 0.60 & 0.45 & 0.044 & 9.76 \\
Macrozooecia width, mm & 30 & 0.52 & 0.60 & 0.55 & 0.021 & 3.87 \\
Macrozooecia spacing, mm & 30 & 0.53 & 0.63 & 0.57 & 0.032 & 5.66 \\
Lunarium thickness, mm & 25 & 0.05 & 0.11 & 0.08 & 0.018 & 24.32 \\
Diaphragm spacing, mm & 20 & 0.25 & 0.65 & 0.44 & 0.097 & 22.15 \\
Exilazooecia width, mm & 25 & 0.06 & 0.19 & 0.12 & 0.034 & 29.28 \\
\hline
\end{tabular}

Description. - Colonies usually massive hemispherical, discoidal, sometimes irregular massive, multilayered and composed of several subcolonies. Hemispherical colonies $6-30 \mathrm{~mm}$ thick in its central part and $17-45 \mathrm{~mm}$ wide at their bases. Massive multilayered colonies up to $45 \times 45 \mathrm{~mm}$ in size. Secondary overgrowth $6.9-16.0 \mathrm{~mm}$ thick. Exozone indistinct. Autozooecia long, prismatic, growing from epitheca. Epitheca $0.01-0.02 \mathrm{~mm}$ thick.
Autozooecial apertures polygonal, 4.4-5.8 spaced per $1 \mathrm{~mm}^{2}$. Diaphragms straight, rare to common, widely spaced, locally abundant. Heterozooecia sensu stricto not observed; immature zooids of smaller diameter locally present. Acanthostyles absent. Autozooecial walls indistinctly granular, irregularly thickened, $0.01-0.03 \mathrm{~mm}$ thick. Maculae indistinct, composed of macrozooecia.

Remarks. - Dianulites collucatus Pushkin, 2001 in Pushkin \& Popov (2001) differs from D. petropolitanus (Dybowski, 1877) in having smaller autozooecial apertures (aperture width $0.30-0.51 \mathrm{~mm} v s .0 .58-0.70 \mathrm{~mm}$ in D. petropolitanus). Dianulites collucatus differs from D. janischevskyi Modzalevskaya, 1953 in having slightly larger autozooecia (aperture width $0.30-0.51 \mathrm{~mm}$ vs. $0.25-0.40 \mathrm{~mm}$ in D. janischevskyi) and in having indistinct maculae composed of macrozooecia vs. maculae composed of smaller zooecia in D. janischevskyi.

Occurrence. - Obukhovo Fm., Kunda Stage, Darriwilian, Middle Ordovician; Putilovo quarry, Russia. Kunda Stage, Darriwilian, Middle Ordovician; Aseri quarry, Harku quarry, Estonia.

\section{Dianulites pakriensis sp. nov.}

Figure 4E-H, 5A-C; Table 3

Holotype. - GIT 537-1294a-d (four thin sections) originally assigned to Dianulites robustus Männil, 1959 (unpublished).

Table 3. Descriptive statistics of Dianulites pakriensis sp. nov. (one colony measured). Abbreviations as for Table 1 .

\begin{tabular}{lcccccc}
\hline & $\mathrm{N}$ & $\mathrm{MIN}$ & $\mathrm{MAX}$ & $\mathrm{X}$ & $\mathrm{SD}$ & $\mathrm{CV}$ \\
\hline Aperture width, mm & 20 & 0.32 & 0.55 & 0.40 & 0.049 & 12.41 \\
Aperture spacing, mm & 20 & 0.46 & 0.70 & 0.54 & 0.057 & 10.65 \\
Mesozooecia width, mm & 20 & 0.07 & 0.17 & 0.12 & 0.028 & 23.21 \\
Mesozooecia per aperture & 20 & 2.00 & 6.00 & 4.00 & 1.124 & 28.10 \\
Lunarium thickness, mm & 25 & 0.05 & 0.11 & 0.08 & 0.018 & 24.32 \\
Diaphragm spacing, mm & 20 & 0.25 & 0.65 & 0.44 & 0.097 & 22.15 \\
Exilazooecia width, mm & 25 & 0.06 & 0.19 & 0.12 & 0.034 & 29.28 \\
\hline
\end{tabular}

Paratypes. - GIT 537-1295 and GIT 537-2004.

Type horizon and locality. - Kunda Stage, Darriwilian, Middle Ordovician; Väike-Pakri island, Estonia.

Material. - Types only.

Etymology. - The species is named after finding near Pakri, Estonia. 

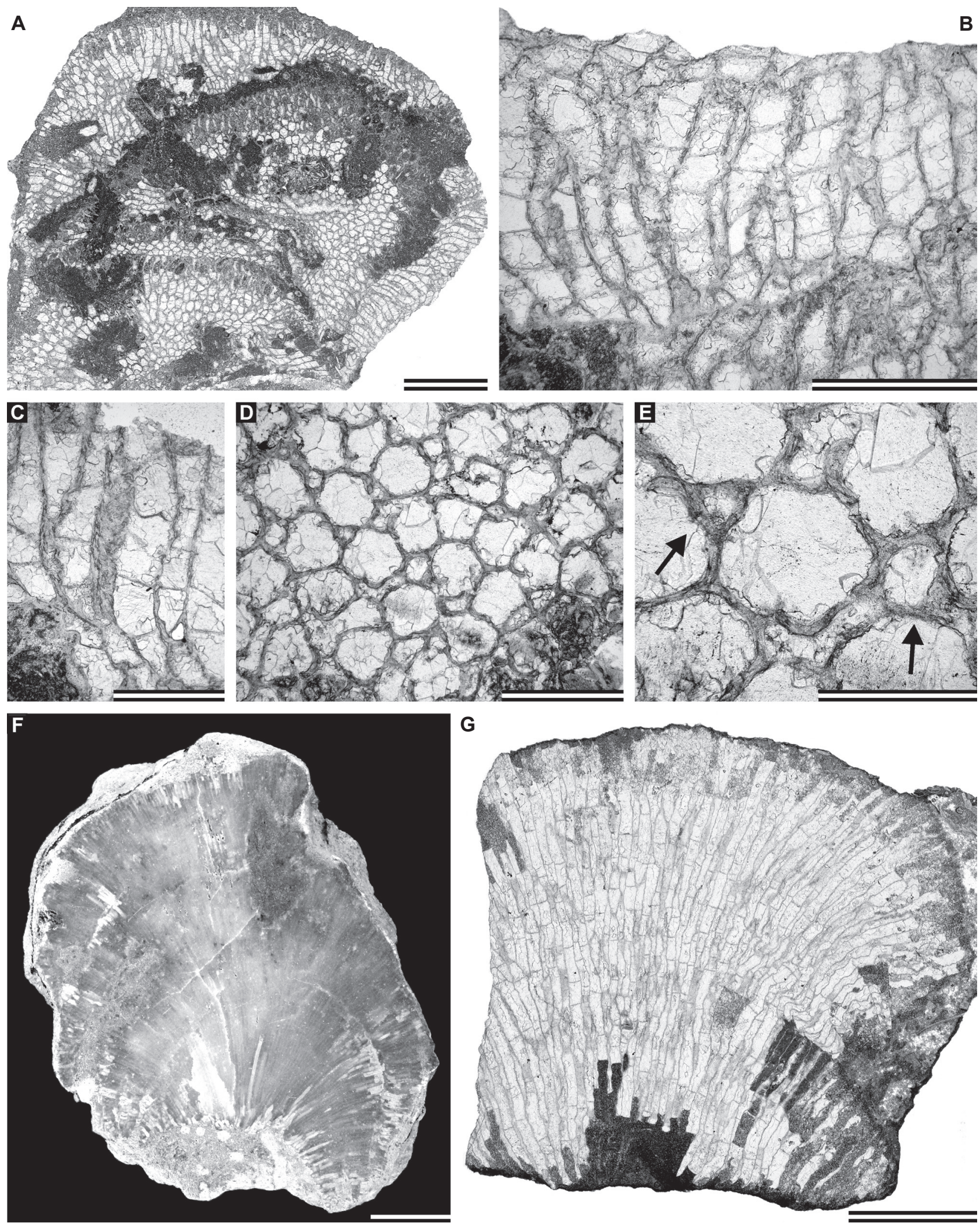

Figure 3. A-E - Ceramopora magnicellularis Männil \& Pushkin, 1990 in Pushkin (1990); A - longitudinal section through the multilayered colony, GIT 155-2041b; B, C - longitudinal section of separate sheets, GIT 155-2041b; D, E - tangential section showing autozooecial apertures and exilazooecia (arrows), GIT 155-2041d. • F, G - Dianulites collucatus Pushkin, 2001 in Pushkin \& Popov (2001); F - fragment of the colony cut in the middle, GIT 852-24; G - thin section through the middle part of the colony, GIT 852-26a. Scale bars: $19 \mathrm{~mm}$ (F), $5 \mathrm{~mm}(\mathrm{~A}, \mathrm{G}), 1 \mathrm{~mm}(\mathrm{~B}-\mathrm{D}), 0.5 \mathrm{~mm}$ (E). 
Diagnosis. - Large ramose colonies with indistinct exozones; secondary overgrowth occurring; autozooecial diaphragms absent; $3.5-4.5$ autozooecial apertures per $1 \mathrm{~mm}^{2}$; heterozooecia (immature zooecia?) abundant, 2-5 surrounding each autozooecial aperture; acanthostyles absent; maculae composed of immature zooecia (zooecia smaller in size but identical to normal autozooecia in shape and budding pattern).

Description. - Large ramose colonies with indistinct exozones. Branches $19-28 \mathrm{~mm}$ in diameter. Secondary overgrowth 1.6-2.4 $\mathrm{mm}$ in thickness. Autozooecia long, prismatic, growing parallel to branch axis and bending at low angles in exozones. Diaphragms absent. Autozooecial apertures polygonal, 3.5-4.5 spaced per $1 \mathrm{~mm}^{2}$. Tubes of smaller diameter (immature zooecia?) between autozooecia abundant, $2-5$ surrounding each autozooecial aperture, rounded-polygonal, restricted to the outer exozone. Acanthostyles absent. Autozooecial walls indistinctly granular, irregularly thickened, $0.015-$ $0.030 \mathrm{~mm}$ thick. Maculae composed of immature zooecia present, $1.15-1.25 \mathrm{~mm}$ in diameter.

Remarks. - According to the rules of the Zoological Nomenclature, the species Dianulites robustus of Männil in his dissertation (1959) is not valid. Therefore, his material has been used to establish a new species. Dianulites pakriensis sp. nov. differs from D. petropolitanus (Dybowski, 1877) in having smaller autozooecial apertures (aperture width $0.32-0.55 \mathrm{~mm}$ vs. $0.58-0.70 \mathrm{~mm}$ in D. petropolitanus) and in absence of diaphragms. Dianulites pakriensis differs from $D$. janischevskyi Modzalevskaya, 1953 in having larger autozooecia (aperture width $0.32-0.55 \mathrm{~mm}$ vs. $0.25-0.40 \mathrm{~mm}$ in D. janischevskyi). Dianulites pakriensis differs from D. collucatus Pushkin, 2001 in Pushkin \& Popov (2001) in colony shape (ramose vs. hemispheric massive), in absence of diaphragms and in presence of maculae composed of immature zooecia.

\section{Genus Esthoniopora Bassler, 1911}

Type species. - E. communis Bassler, 1911. Middle Ordovician, Darriwilian; Estonia.

Diagnosis. - Massive, usually hemispherical colonies. Autozooecia with polygonal apertures and thin straight walls. Diaphragms abundant, perforated, planar or sloped, sometimes like cystiphragms. Acanthostyles absent (modified after Astrova 1978).

Remarks. - Esthoniopora Bassler, 1911 differs from Esthonioporella Modzalevskaya, 1953 in absence of acanthostyles and in having thin autozooecial walls.
Occurrence. - Lower-Upper Ordovician; Estonia, NW Russia, Norway.

\section{Esthoniopora communis Bassler, 1911}

Figure 5D-G; Table 4

1911 Esthoniopora communis Bassler; pp. 260-263, text-figs 151-155.

1978 Esthoniopora communis Bassler, 1911. - Astrova, pl. 1, fig. 1.

2002 Esthoniopora communis Bassler, 1911. - Pushkin, p. 116 , fig. $3 \mathrm{~h}-\mathrm{j}$.

Material. - Single specimen GIT 155-2048a-d (four thin sections).

Table 4. Descriptive statistics of Esthoniopora communis Bassler, 1911 (one colony measured). Abbreviations as for Table 1.

\begin{tabular}{lcccccc}
\hline & $\mathrm{N}$ & MIN & MAX & $\mathrm{X}$ & $\mathrm{SD}$ & $\mathrm{CV}$ \\
\hline Aperture width, mm & 20 & 0.33 & 0.52 & 0.39 & 0.047 & 12.10 \\
Aperture spacing, mm & 20 & 0.35 & 0.56 & 0.43 & 0.049 & 11.21 \\
Mesozooecia width, mm & 11 & 0.06 & 0.14 & 0.10 & 0.030 & 29.40 \\
Hemiphragm spacing, mm & 20 & 0.20 & 0.41 & 0.27 & 0.047 & 17.53
\end{tabular}

Description. - Massive hemispheric colony, $22 \mathrm{~mm}$ wide at its base and $16 \mathrm{~mm}$ high in its central part. Secondary overgrowth occurring, 1.4-1.9 mm thick. Exozone indistinct. Autozooecia long, prismatic, growing from epitheca. Epitheca $0.005-0.010 \mathrm{~mm}$ thick. Autozooecial apertures polygonal, 5.1-5.6 spaced per $1 \mathrm{~mm}^{2}$. Mesozooecia sensu stricto absent, immature zooecia smaller than autozooecia common, $0.06-0.14 \mathrm{~mm}$ in diameter. Hemiphragms abundant, restricting more than half of the autozooecial chamber space, curved proximally, tapering to their ends. Autozooecial walls amalgamated, 0.020 $0.025 \mathrm{~mm}$ thick in endozone and $0.03-0.05 \mathrm{~mm}$ thick in exozone. Maculae not observed.

Remarks. - Esthoniopora communis Bassler, 1911 differs from E. subsphaerica (Bassler, 1911) in having larger autozooecia (average aperture width $0.39 \mathrm{~mm} v s .0 .25 \mathrm{~mm}$ in E. subsphaerica; measurements for E. subsphaerica from Ernst \& Nakrem 2011).

Occurrence. - The studied material comes from the Kunda Stage (Darriwilian, Middle Ordovician) of Aseri cliff, Estonia. Esthoniopora communis Bassler, 1911 is a common species in the Lower to Middle Ordovician of Estonia and Belarus, as well as Norway (unpublished).

Family Revalotrypidae Gorjunova, 1988 

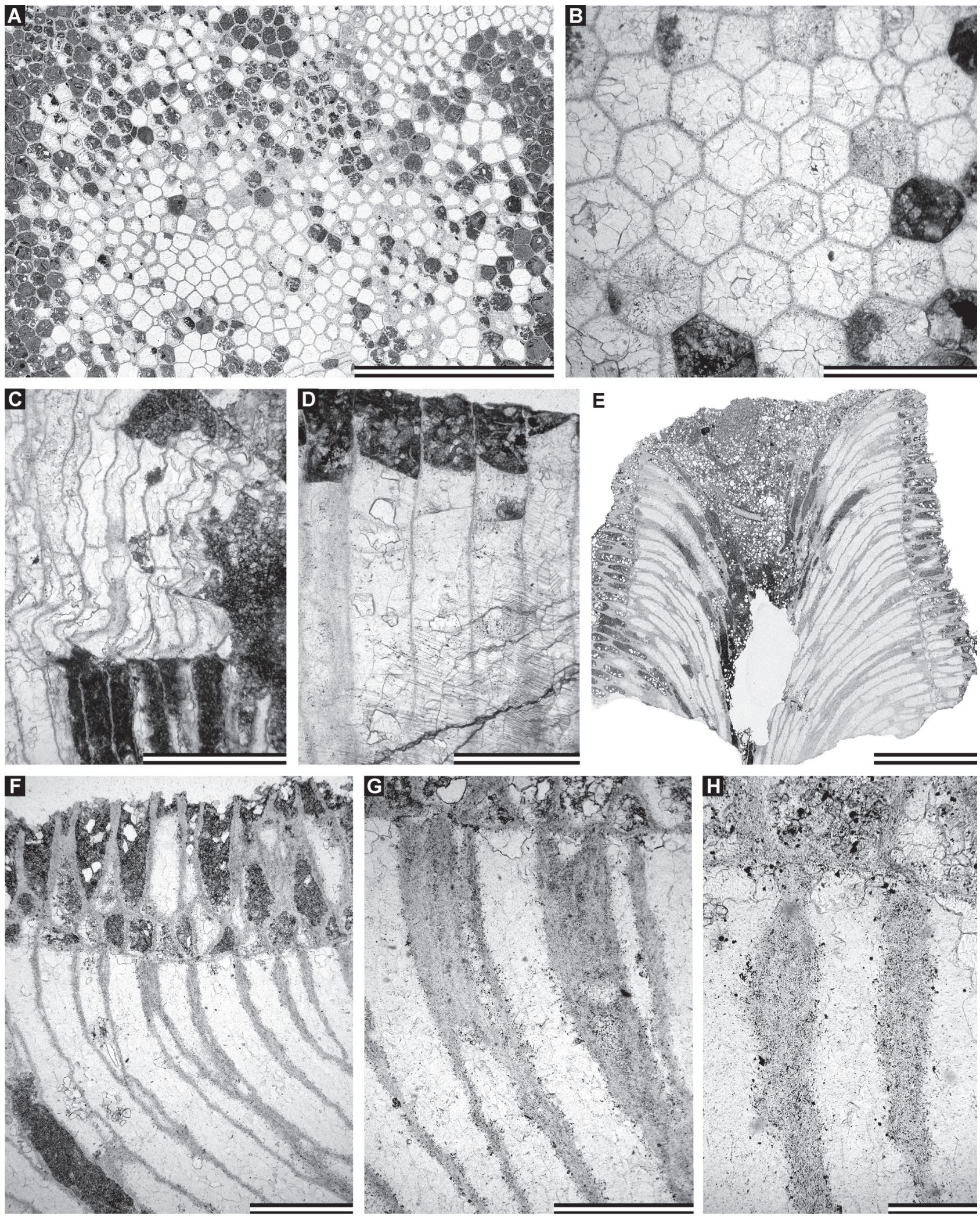

Figure 4. A-D - Dianulites collucatus Pushkin, 2001 in Pushkin \& Popov (2001); A - tangential section, GIT 852-1d; B - tangential section, GIT 852-24d; C - longitudinal section, GIT 852-26a; D - longitudinal section, GIT 852-24a. • E-H - Dianulites pakriensis sp. nov. Holotype GIT 537-1294b, longitudinal thin section showing autozooecial chambers and secondary overgrowths. Scale bars: $5 \mathrm{~mm}$ (A, E), $2 \mathrm{~mm}$ (C), $1 \mathrm{~mm}$ (B, D, F, G), $0.5 \mathrm{~mm}(\mathrm{H})$. 


\section{Genus Revalotrypa Bassler, 1952}

Type species. - Nicholsonella gibbosa Bassler, 1911. Ordovician; Estonia.

Diagnosis. - Colonies encrusting laminate (unilaminate and multilaminate), massive discoidal, hemispherical, mushroomlike, nodular, rodlike, and branched ramose. Endozones poorly defined. Autozooecia tubular, growing from thick epitheca. Diaphragms widely spaced, straight or concave. Autozooecial apertures circular to oval. Neozooecia arranged around autozooecia, occasionally forming accumulations. Apertures of exilazooecia circular, oval, or irregularly triangular or tetragonal, varying in size. Acanthostyles absent. Autozooecial walls granular, straight to strongly crenulated.

Remarks. - Revalotrypa Bassler, 1952 is unique because of its granular (re-crystallized) walls which this genus shares with Nicholsonella Ulrich, 1890 or Dianulites Eichwald, 1829. Such a wall structure suggests a diagenetically unstable aragonitic (McKinney 1971) or high-magnesium calcite composition (Taylor \& Wilson 1999). However, Dianulites hardly possesses any heteromorphs (obscure mesozooecia), whereas Nicholsonella has common to abundant mesozooecia with frequent diaphragms as well as acanthostyles.

Occurrence. - Lower to Middle Ordovician of Russia and China, Upper Ordovician (Katian) of Morocco, Upper Ordovician (Hirnantian) of Canada.

\section{Revalotrypa gibbosa (Bassler, 1911)}

Figure 6A-F; Table 5

1911 Nicholsonella gibbosa Bassler; p. 224, pl. 2, figs 1-6. 1988 Revalotrypa gibbosa (Basler, 1911). - Gorjunova, p. 35, pl. 3, figs 2,3 .

2011 Revalotrypa gibbosa (Basler, 1911). - Koromyslova, p. 917 , pl. 3, figs 1-3, pl. 4, figs 1, 2.

Material. - Fourteen colonies GIT 381-21a, GIT 1552056a-c, GIT 852-3a, GIT 852-5a-c, GIT 852-9a-b, GIT 852-10a, GIT 852-11a-b, GIT 852-12a-b, GIT 852-13a-b, GIT 852-14a-c, GIT 852-15a-b, GIT 852-16a-c, GIT 852-17a, GIT 852-19 (twenty-six thin sections).

Description. - Colonies mainly mushroomlike, consisting of several encrusting subcolonies growing in series. Subcolonies $0.4-3.3 \mathrm{~mm}$ thick in their central parts. Autozooecia tubular, growing from $0.010-0.020 \mathrm{~mm}$ thick epitheca. Autozooecial apertures rounded to slightly polygonal, 4.9-7.2 spaced per $1 \mathrm{~mm}^{2}$. Autozooecial diaphragms uncommon. Neozooecia abundant, 8-17 sur- rounding each autozooecial aperture and 28-45 spaced per $1 \mathrm{~mm}^{2}$, large, with polygonal apertures. Autozooecial walls granular, straight but locally strongly crenulated, $0.05-0.015 \mathrm{~mm}$ thick. Indistinct maculae consisting of slightly larger zooecia.

Table 5. Descriptive statistics of Revalotrypa gibbosa (Bassler, 1911) (seven colonies measured). Abbreviations as for Table 1.

\begin{tabular}{lcccccc}
\hline & $\mathrm{N}$ & MIN & MAX & X & SD & CV \\
\hline Aperture width, mm & 86 & 0.22 & 0.43 & 0.31 & 0.040 & 12.88 \\
Aperture spacing, mm & 81 & 0.28 & 0.55 & 0.41 & 0.050 & 12.40 \\
Mesozooecia width, mm & 86 & 0.04 & 0.19 & 0.08 & 0.028 & 33.99 \\
Mesozooecia per aperture & 49 & 8.0 & 17.0 & 11.8 & 2.294 & 19.38 \\
\hline
\end{tabular}

Remarks. - Revalotrypa gibbosa (Bassler, 1911) differs from $R$. eugeniae Gorjunova, 1988 in having larger autozooecial apertures (aperture width $0.22-0.43 \mathrm{~mm}$ vs. $0.25-0.27 \mathrm{~mm}$ in $R$. eugeniae). Revalotrypa gibbosa differs from $R$. papillaris (Modzalevskaya, 1953) in its colony form (mushroomlike vs. rod-shaped in R. papillaris) and in having larger autozooecial apertures (aperture width $0.22-0.43 \mathrm{~mm}$ vs. $0.22-0.27 \mathrm{~mm}$ in R. papillaris). Revalotrypa gibbosa differs from $R$. krestensis Koromyslova, 2008 in Gorjunova \& Koromyslova (2008) in having larger autozooecial apertures (aperture width $0.22-0.43 \mathrm{~mm} v s .0 .20-0.34 \mathrm{~mm}$ in $R$. krestensis).

Occurrence. - Kunda Stage, Darriwilian, Middle Ordovician; Väike-Pakri island, Harku quarry, Estonia. Obukhovo Fm., Kunda Stage, Darriwilian, Middle Ordovician; Putilovo quarry, Russia.

\section{Revalotrypa papillaris (Modzalevskaya, 1953)}

Figure 6G, H; 7A, B

1953 Nicholsonella papillaris Modzalevskaya; p. 127, pl. 5, figs 1-3, text-fig. 12.

1953 Nicholsonella rotundicellularis Modzalevskaya; p. 128, pl. 5, figs 4, 5, text-fig. 13.

2011 Revalotrypa papillaris (Modzalevskaya, 1953). Koromyslova, pp. 917-919, pl. 5, fig. 1.

Material. - GIT 852-7a (one thin section), GIT 852-20.

Description. - Colonies rod- or club-shaped, with flat bases, $2.60-2.85 \mathrm{~mm}$ in diameter. Autozooecia tubular, growing directly from the base. Autozooecial apertures rounded to slightly polygonal, $0.18-0.27 \mathrm{~mm}$ wide. Autozooecial diaphragms uncommon. Neozooecia abundant, $0.04-0.07 \mathrm{~mm}$ in diameter. Autozooecial walls granular, straight but locally strongly crenulated, 0.010 $0.018 \mathrm{~mm}$ thick. Maculae not observed. 

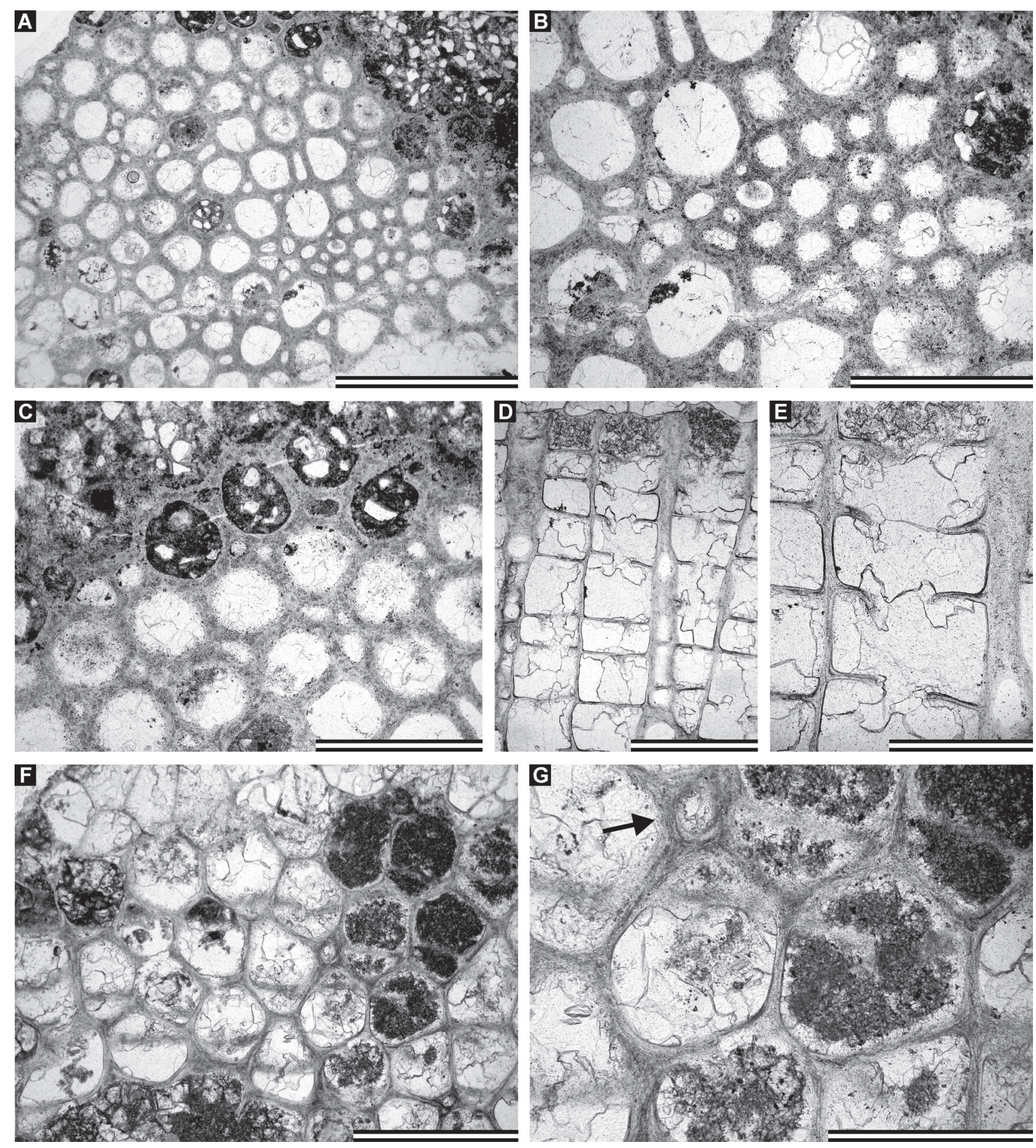

Figure 5. A-C - Dianulites pakriensis sp. nov. Holotype GIT 537-1294d, tangential section showing autozooecial apertures, heterozooecia (immature zooecia?), and a macula, composed of heterozooecia. $・ \mathrm{D}-\mathrm{G}-$ Esthoniopora communis Bassler, 1911; D, E - longitudinal section showing autozooecial chambers with hemiphragms, GIT 155-2048b; F, G - tangential section showing autozooecial apertures and immature zooecia (arrow), GIT 155-2048d. Scale bars: $2 \mathrm{~mm}$ (A), $1 \mathrm{~mm}$ (B-D, F), 0.5 (E, G).

Remarks. - Revalotrypa papillaris (Modzalevskaya, 1953) differs from all species of the genus in its rod-shape colony and abundant small neozooecia. Revalotrypa papillaris differs from R. eugeniae Gorjunova, 1988 in having rod- shaped colony vs. laminar encrusting one in the latter genus. Revalotrypa papillaris differs from $R$. krestensis Koromyslova, 2008 in Gorjunova \& Koromyslova (2008) in its rodshaped colony instead of massive one in the latter species. 
Occurrence. - Studied material comes from the Obukhovo Fm. (Kunda Stage, Darriwilian, Middle Ordovician) of the Putilovo quarry, Russia.

\section{Genus Orbipora Eichwald, 1856}

Type species. - Orbitulites distinctus Eichwald, 1829. Middle Ordovician of Estonia and Sweden.

Diagnosis. - Massive colonies. Autozooecia large with irregular polygonal apertures and amalgamated structureless walls, indistinctly thickened. Diaphragms rare to absent, locally numerous. Abundant acanthostyles of different shape and size, typically with wide hyaline cores and narrow laminated sheaths. Heterozooecia absent (after Astrova 1978).

Remarks. - The genus Orbipora Eichwald, 1856 differs from the genus Nekhorosheviella Modzalevskaya, 1953 in shape and sizes of acanthostyles, such as in usually rare diaphragms. The single known species of the latter genus, Nekhorosheviella cribrosa Modzalevskaya, 1953 has two distinct types of acanthostyles - large with wide calcitic cores, and small ones, positioned in middle parts of walls. Furthermore, it has indistinctly lamellar walls and abundant diaphragms in autozooecia.

Occurrence. - Lower-Middle Ordovician of the Baltoscandian region; Middle Ordovician of the Northern America.

\section{Orbipora indenta Bassler, 1911}

Figure 7C-F; Table 6

1911 Orbipora indenta Bassler; pp. 257, 258, text-fig. $150 \mathrm{a}-\mathrm{d}$.

non 1996 Orbipora indenta Bassler, 1911. - Buttler \& Massa, fig. $4 \mathrm{~b}$.

non 2007 Orbipora indenta Bassler, 1911. - Buttler, Cherns \& Massa, pp. 484, 485, pl. 1, figs 1-3.

Material. - Single specimen GIT 155-2043a-c (three thin sections).

Description. - Massive hemispheric colony, ca. $14 \mathrm{~mm}$ wide at its base and $9 \mathrm{~mm}$ high in its central part. Secondary overgrowth not observed. Exozone indistinct. Autozooecia long, prismatic. Epitheca not seen in this sample. Autozooecial apertures polygonal, 6.4-6.9 spaced per $1 \mathrm{~mm}^{2}$. Autozooecial diaphragms few, straight. Acanthostyles large, deeply indenting into the autozooecial cavity, 4-7 surrounding each autozooecial aperture. Autozooecial walls amalgamated, $0.025-0.030 \mathrm{~mm}$ thick. Maculae not observed.
Table 6. Descriptive statistics of Orbipora indenta Bassler, 1911 (one colony measured). Abbreviations as for Table 1.

\begin{tabular}{lcccccc}
\hline & $\mathrm{N}$ & MIN & MAX & X & SD & CV \\
\hline Aperture width, mm & 20 & 0.25 & 0.40 & 0.32 & 0.044 & 13.82 \\
Aperture spacing, mm & 20 & 0.30 & 0.48 & 0.39 & 0.053 & 13.69 \\
Acanthostyle diameter, mm & 20 & 0.06 & 0.10 & 0.08 & 0.013 & 16.15 \\
Acanthostyles per aperture & 20 & 4.0 & 7.0 & 4.85 & 1.040 & 21.44 \\
\hline
\end{tabular}

Remarks. - Orbipora indenta Bassler, 1911 differs from other species of Orbipora by large acanthostyles deeply indenting into the autozooecial cavity. It differs from Orbipora acanthophora Bassler, 1911 in having smaller autozooecial apertures and less abundant acanthostyles (see below).

The species described as Orbipora indenta Bassler, 1911 by Buttler \& Massa (1996) and Buttler et al. (2007) from the Upper Ordovician (Katian) of Libya, does not belong to this species. It has different wall structure and morphology of acanthostyles with wide dark laminated sheaths and narrow hyaline cores.

Occurrence. - Kunda Stage, Darriwilian, Middle Ordovician; Väike-Pakri cliff, Estonia (present material). Bassler (1911) reported his material from the lower Asaphus Limestone (Kunda Stage) at Hälludden, island of Öland, Sweden.

\section{Orbipora acanthophora Bassler, 1911}

Figure 7G, 8A-E; Table 7

1911 Orbipora acanthophora Bassler; pp. 255-257, text-fig. 149a-d.

2007 Orbipora acanthophora Bassler, 1911. - Koromyslova, pp. 139-143, pl. 4, figs 1-2.

Material. - Two colonies GIT 155-2051a-h and GIT 155$2053 \mathrm{a}-\mathrm{c}$ (eleven thin sections).

Table 7. Descriptive statistics of Orbipora acanthophora Bassler, 1911 (two colonies measured). Abbreviations as for Table 1.

\begin{tabular}{lcccccc}
\hline & $\mathrm{N}$ & $\mathrm{MIN}$ & $\mathrm{MAX}$ & $\mathrm{X}$ & $\mathrm{SD}$ & $\mathrm{CV}$ \\
\hline Aperture width, mm & 50 & 0.35 & 0.57 & 0.44 & 0.050 & 11.26 \\
Aperture spacing, mm & 50 & 0.40 & 0.68 & 0.52 & 0.064 & 12.31 \\
Acanthostyle diameter, mm & 50 & 0.03 & 0.17 & 0.09 & 0.030 & 34.02 \\
Acanthostyles per aperture & 20 & 6.0 & 11.0 & 7.7 & 1.694 & 22.15 \\
Mesozooecia width, mm & 26 & 0.08 & 0.27 & 0.16 & 0.050 & 31.07
\end{tabular}

Description. - Massive multilayered, irregularly shaped colonies of maximum size by $20 \times 30 \mathrm{~mm}$. Secondary overgrowths $1.9-5.8 \mathrm{~mm}$ in thickness. Exozone in- 


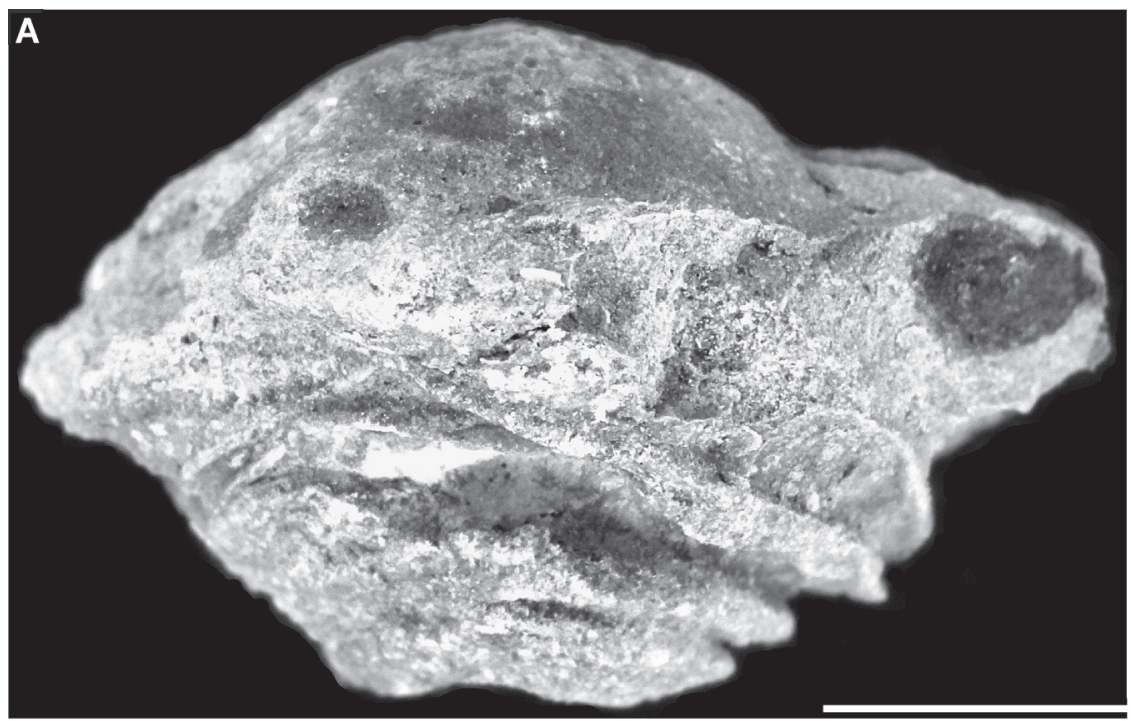

B
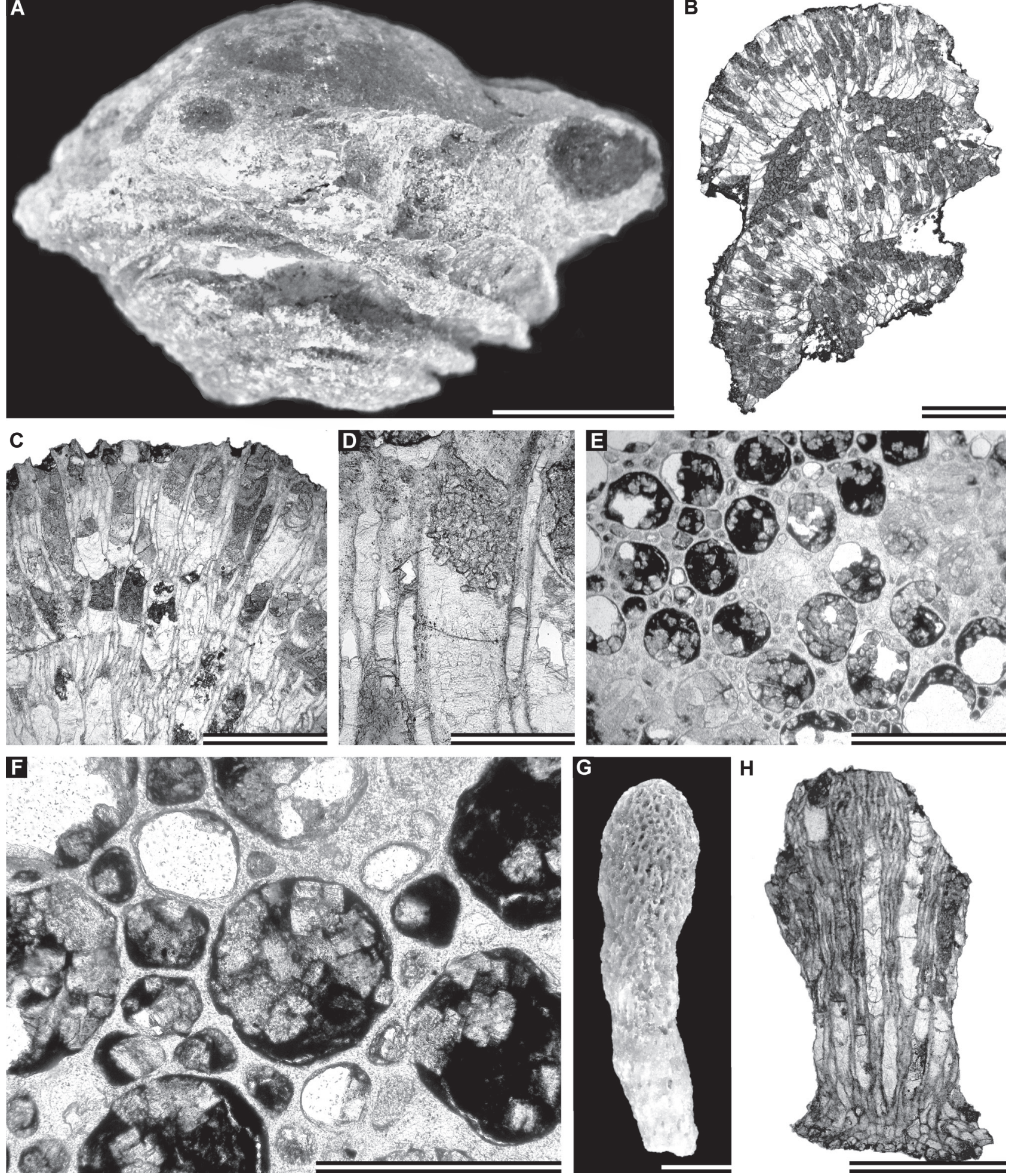

Figure 6. A-F - Revalotrypa gibbosa (Bassler, 1911); A - separate hemispheric multilayered colony, GIT 852-19; B - thin section through the hemispheric multilayered colony, GIT 852-16b; C, D - longitudinal section showing autozooecial chambers and neozooecia, GIT 852-13a; E, F - tangential section showing autozooecial apertures and neozooecia, GIT 852-13b. • G, H - Revalotrypa papillaris (Modzalevskaya, 1953); $\mathrm{G}$ - fragment of a colony, GIT 852-20; H - longitudinal section showing autozooecial chambers and neozooecia, GIT 852-7a. Scale bars: $5 \mathrm{~mm}$ (A), $2 \mathrm{~mm}(\mathrm{~B}, \mathrm{C}, \mathrm{G}, \mathrm{H}), 1 \mathrm{~mm}(\mathrm{E}), 0.5 \mathrm{~mm}(\mathrm{D}, \mathrm{F})$, 
distinct. Autozooecia long, prismatic growing from $0.005-0.010 \mathrm{~mm}$ thick epitheca. Autozooecial apertures polygonal, 2-5 spaced per $1 \mathrm{~mm}^{2}$. Autozooecial diaphragms few, straight. Acanthostyles large, slightly indenting into the autozooecial cavity, 6-11 surrounding each autozooecial aperture and 7-12 spaced per $1 \mathrm{~mm}^{2}$. Autozooecial walls amalgamated, $0.035-0.060 \mathrm{~mm}$ thick. Maculae not observed.

Remarks. - Orbipora acanthophora Bassler, 1911 is similar to $O$. distincta (Eichwald, 1829) but differs from it in having less abundant acanthostyles (6-11 per aperture vs. 15-20 in O. distincta). Orbipora acanthophora differs from O. indenta Bassler, 1911 in having larger autozooecial apertures (average aperture width $0.44 \mathrm{~mm}$ vs. $0.32 \mathrm{~mm}$ in $O$. indenta) and more abundant acanthostyles (6-11 acanthostyles per aperture vs. 4-7 in O. indenta).

Occurrence. - Kunda Stage, Darriwilian, Middle Ordovician; Harku quarry, Estonia (present material). Bassler (1911) reported his material from the lower Asaphus Limestone (Kunda Stage) at Hälludden, island of Öland, Sweden. Koromyslova (2007, p. 139) gives the range of O. acanthophora from the Kunda Stage of Sweden and NW Russia to the Uhaku Stage of Estonia.

\section{Orbipora aff. distincta (Eichwald, 1829)}

Figure 8F-H; 9A, B; Table 8

Material. - Single colony GIT 852-2a-d (four thin sections).

Table 8. Descriptive statistics of Orbipora aff. distincta (Eichwald, 1829) (one colony measured). Abbreviations as for Table 1.

\begin{tabular}{lcccccc}
\hline & $\mathrm{N}$ & $\mathrm{MIN}$ & $\mathrm{MAX}$ & $\mathrm{X}$ & $\mathrm{SD}$ & $\mathrm{CV}$ \\
\hline Aperture width, mm & 20 & 0.20 & 0.40 & 0.31 & 0.054 & 17.52 \\
Aperture spacing, mm & 20 & 0.30 & 0.47 & 0.38 & 0.046 & 12.16 \\
Acanthostyle diameter, mm & 20 & 0.030 & 0.055 & 0.042 & 0.008 & 18.27 \\
Acanthostyles per aperture & 8 & 11 & 20 & 17 & 2.976 & 17.51 \\
\hline
\end{tabular}

Description. - Massive hemispheric colony encrusting a cephalopod shell, $8.1 \mathrm{~mm}$ wide at its base and $4.5 \mathrm{~mm}$ high in its central part. Secondary overgrowth not observed. Exozone indistinct. Autozooecia long, prismatic.
Epitheca not seen in this sample. Autozooecial apertures polygonal, 9-10 spaced per $1 \mathrm{~mm}^{2}$. Autozooecial diaphragms few, straight. Acanthostyles moderate in size, not exceeding the wall thickness and not indenting into the autozooecial cavity, 11-20 arranged in one row around each autozooecial aperture and 55-71 spaced per $1 \mathrm{~mm}^{2}$. Autozooecial walls amalgamated, $0.035-0.055 \mathrm{~mm}$ thick. Maculae indistinct, consisting of slightly larger autozooecia.

Remarks. - The present material is most similar to the species Orbipora distincta (Eichwald, 1829) in the number, size, and arrangement of acanthostyles. However, it differs from the material described by Bassler (1911, p. 253) and Koromyslova (2007, p. 144) in having smaller autozooecial apertures. Bassler (1911) measured aperture size as $0.8-1.0 \mathrm{~mm}$, whereas Koromyslova (2007) gave aperture diameters $0.32-0.524 \mathrm{~mm}$. The present material has average aperture diameter of $0.31 \mathrm{~mm}$ (range 0.20 $0.40 \mathrm{~mm})$.

Occurrence. - Kunda Stage, Darriwilian, Middle Ordovician; Harku quarry, Estonia.

Order Trepostomata Ulrich, 1882

Family Dittoporidae Vinassa de Regny, 1921

\section{Genus Dittopora Dybowski, 1877}

Type species. - Dittopora clavaeformis Dybowski, 1877. Lower Ordovician, Arenigian; Estonia, Russia.

Diagnosis. - Ramose colonies. Axial bundle composed of zooecia with diaphragms. Autozooecia and mesozooecia budding from the axial bundle. Autozooecial apertures oval and petaloid. Diaphragms abundant in endozone. Hemiphragms present, usually concentrated in exozone. Mesozooecia abundant, large, usually sealed with calcitic material near colony surface, containing abundant diaphragms. Acanthostyles abundant, often indenting autozooecial apertures. Autozooecial walls hyaline in endozones; indistinctly laminated in exozones. Maculae formed by heterozooecia and acanthostyles present.

Remarks. - Dittopora Dybowski, 1877 differs from Hemiphragma Ulrich, 1893 in the distribution of hemiphragms mainly in the transition between endozone and

Figure 7. A-B - Revalotrypa papillaris (Modzalevskaya, 1953), longitudinal section showing autozooecial chambers and neozooecia, GIT 852-7a. • C-F - Orbipora indenta Bassler, 1911; C, D - longitudinal section, GIT 155-2043b; E - tangential section showing autozooecial apertures and acanthostyles, GIT 155-2043a; F - tangential section showing autozooecial apertures and acanthostyles, GIT 155-2043c. • G - longitudinal thin section containing Orbipora acanthophora Bassler, 1911 and Sonninopora sp. (top right, arrow), GIT 155-2051b. Scale bars: $10 \mathrm{~mm}$ (G), $1 \mathrm{~mm}$ (A, C-E), $0.5 \mathrm{~mm}(\mathrm{~B}, \mathrm{~F})$. 

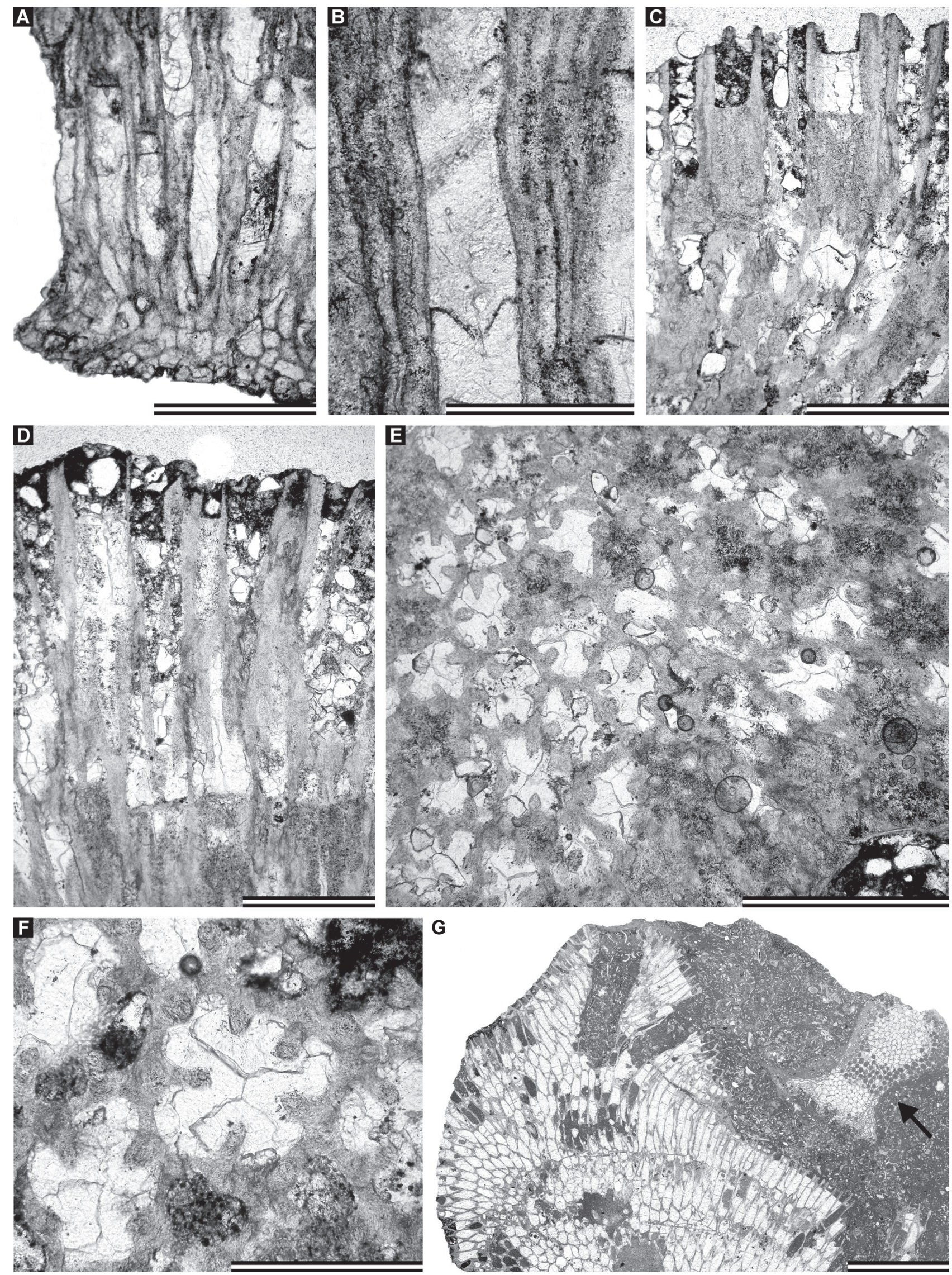

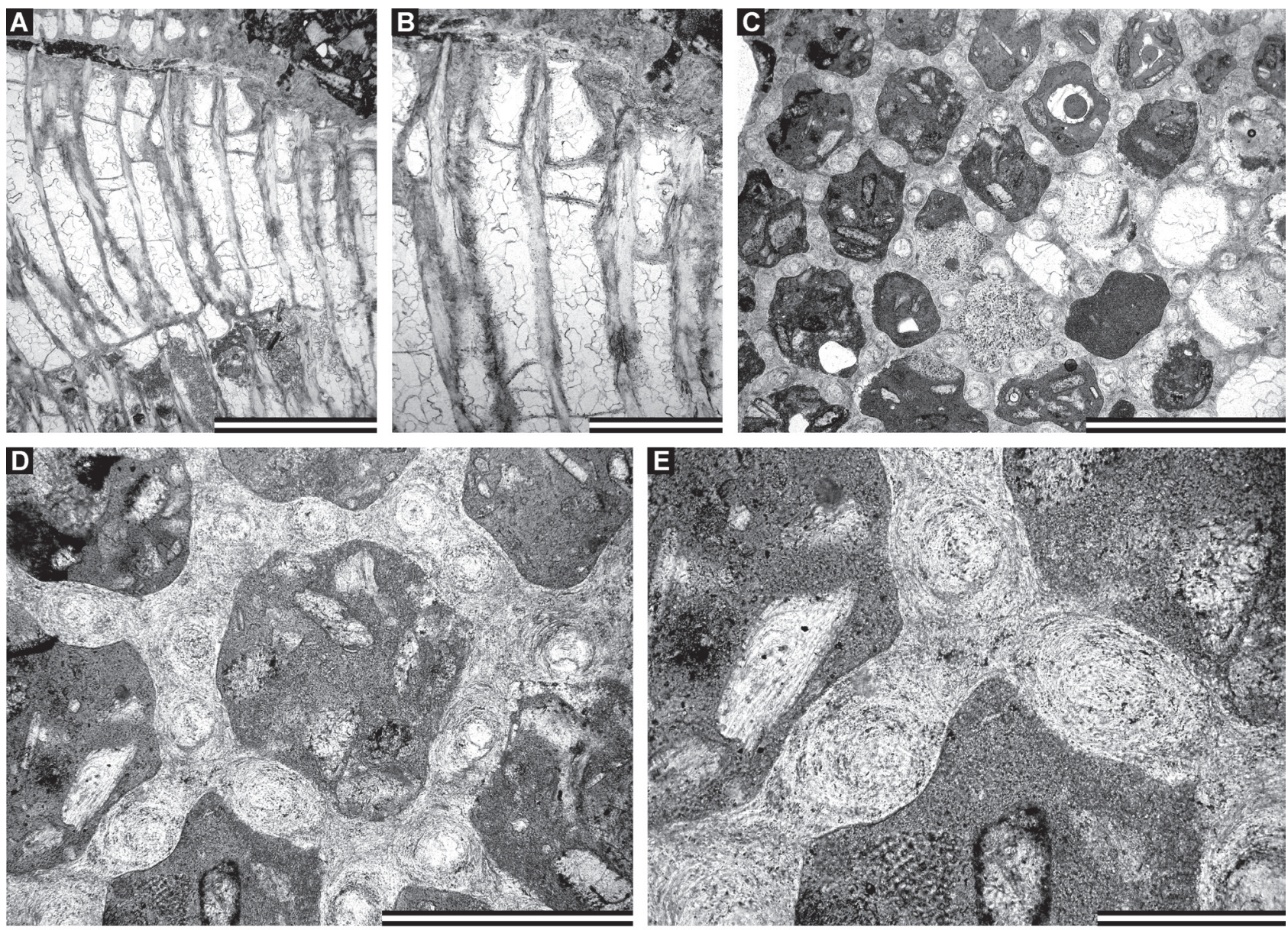

$\mathbf{F}$
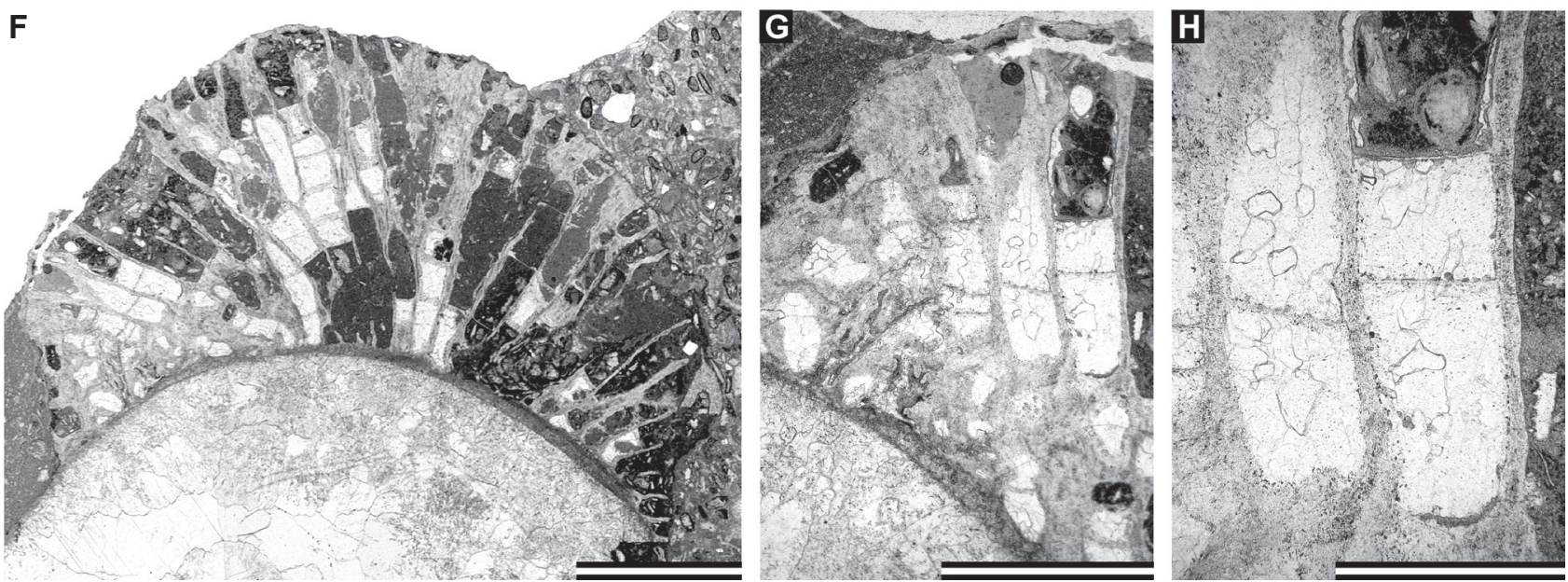

Figure 8. A-E - Orbipora acanthophora Bassler, 1911; A, B - longitudinal section showing autozooecial chambers and acanthostyles, GIT 155-2051b; C-E - tangential section showing autozooecial apertures and acanthostyles, GIT 155-2051g. - F-H - Orbipora aff. distincta (Eichwald, 1829); F - longitudinal section of hemispheric colony on a cephalopod shell, GIT 852-2a; G, H - longitudinal section showing autozooecial chambers with rare diaphragms, GIT 852-2a. Scale bars: $2 \mathrm{~mm}(\mathrm{~A}, \mathrm{~F}), 1 \mathrm{~mm}(\mathrm{~B}, \mathrm{C}, \mathrm{G}), 0.5 \mathrm{~mm}(\mathrm{D}, \mathrm{H}), 0.2 \mathrm{~mm}(\mathrm{E})$.

Figure 9. A, B - Orbipora aff. distincta (Eichwald, 1829), tangential section showing autozooecial apertures and acanthostyles, GIT 852-2d. • C-H - Dittopora sokolovi Modzalevskaya, 1953; C-E - branch longitudinal sections showing autozooecial chambers with hemiphragms (arrows), mesozooecia and acanthostyles, GIT 852-22b; F - branch transverse section, GIT 852-22g; G, H - tangential section showing autozooecial apertures, mesozooecia and acanthostyles, GIT 852-22h. Scale bars: $1 \mathrm{~mm}$ (A, C, D, G), 0.5 (B, F, H), $0.2 \mathrm{~mm}$ (E) 

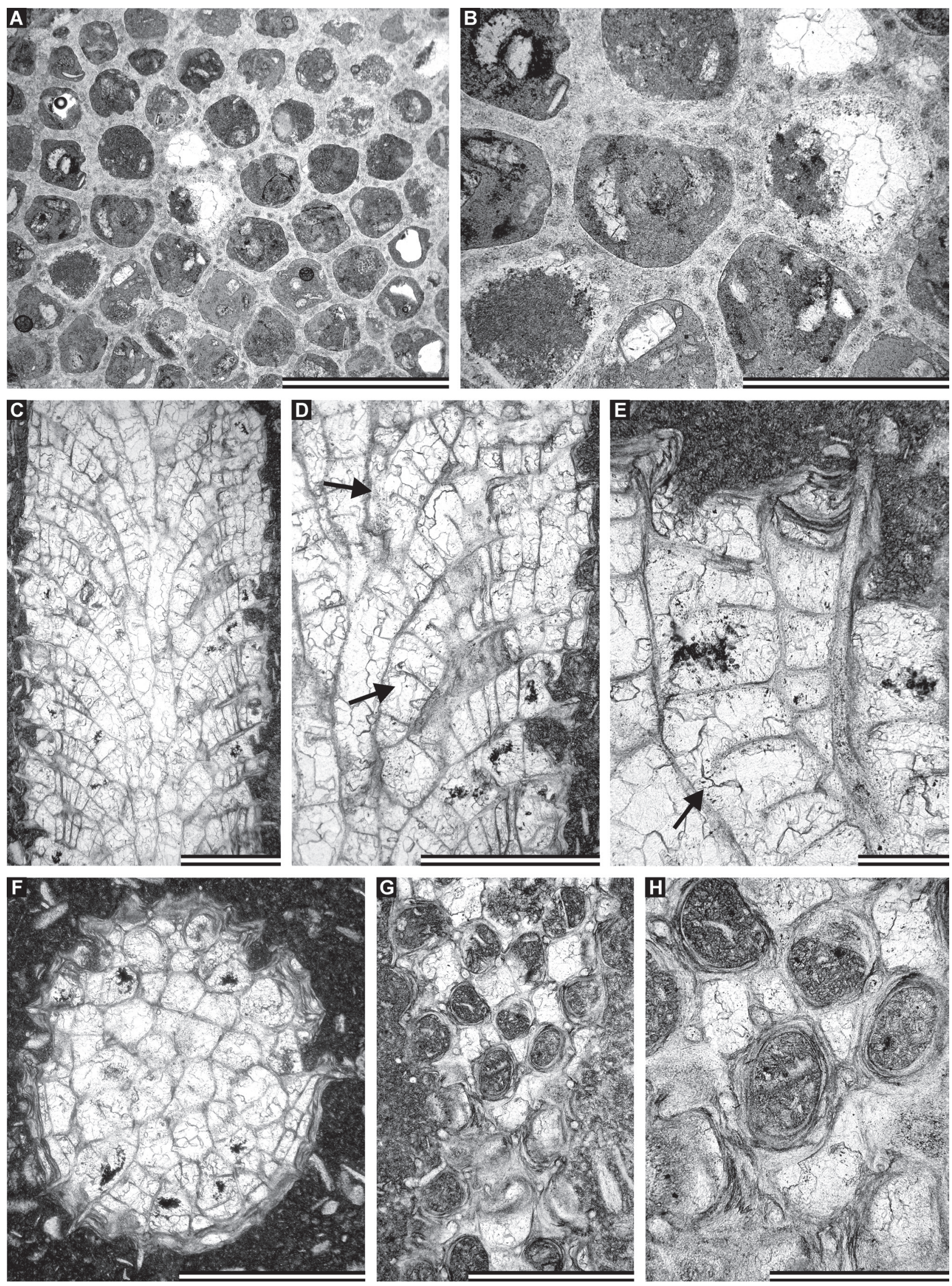
exozone, and in presence of smaller styles in addition to the normal acanthostyles.

Pushkin (1987) established the genus Dybowskites in which he placed the majority of species of Dittopora. He distinguished Dybowskites from Dittopora and Hemiphragma by the presence of the axial bundle of zooecia. However, the type species of Dybowskites, Lioclemella clava Bassler, 1911 does not have hemiphragms and axial bundle of zooecia.

Gorjunova (2005) erected the Family Ralfimartitidae Gorjunova, 2005, in which she placed the genus $D y$ bowskites and restricted this genus to forms without axial bundle. The whole concept of the Family Ralfimartitidae is based on the presence of "aulozooecia", which are described as heterozooecia in form of large hollow spines. However, those are acanthostyles with wide hyaline cores and narrow laminated sheaths (which are interpreted by Gorjunova (2005) as walls of "aulozooecia"). Neither images in Gorjunova (2005) nor own thin sections of bryozoans placed in this family show any signs of hollow spaces in these structures. They must be regarded as unusually large acanthostyles. The genera belonging in the Family Ralfimartitidae Gorjunova, 2005 need critical re-evaluation.

The generic diagnosis of Dittopora Dybowski, 1877 is accepted here after Astrova (1978).

Occurrence. - Lower Ordovician-lower Silurian; Europe (Baltic Region, Belarus, Great Britain).

\section{Dittopora sokolovi Modzalevskaya, 1953}

Figure 9C-H; Table 9

1953 Dittopora sokolovi Mozalevskaya; pp. 161, 162, pl. 13, figs 1-4, text-fig. 30.

1977 Dittopora sp. Pushkin, p. 103, pl. 1, fig. 1.

1987 Dybowskites sokolovi (Modzalevskaya, 1953). Pushkin, p. 162, pl. 12, figs 1, 2.

Material. - Eight thin sections containing five colonies (GIT 852-22a-i).

Description. - Ramose colonies, frequently dichotomizing. Branches $1.95-2.55 \mathrm{~mm}$ in diameter, with $1.10-1.71 \mathrm{~mm}$ wide endozones and $0.37-0.60 \mathrm{~mm}$ wide exozones. Autozooecia long in endozones forming an indistinct axial bundle, bending abruptly in exozones, having polygonal shape in transverse section of endozones.
Autozooecial apertures rounded to slightly polygonal or petaloid, 5-8.6 spaced per $1 \mathrm{~mm}^{2}$. Basal diaphragms few to absent. Hemiphragms abundant, concentrated in the transition between endozone and exozone. Mesozooecia large, abundant, 3-6 surrounding each autozooecial aperture and 9-16 spaced per $1 \mathrm{~mm}^{2}$. Acanthostyles abundant, 2-6 surrounding each autozooecial aperture and 14-21 spaced per $1 \mathrm{~mm}^{2}$, originating in endozones, having distinct hyaline cores and wide laminated sheaths, indenting both autozooecia and mesozooecia. Smaller styles sporadically present between acanthostyles, $0.025-0.030 \mathrm{~mm}$ in diameter. Walls straight, displaying hyaline microstructure, $0.005-0.010 \mathrm{~mm}$ thick in e ndozone; laminated, integrated, $0.04-0.12 \mathrm{~mm}$ thick in exozone. Maculae not observed in the present material.

Table 9. Descriptive statistics of Dittopora sokolovi Modzalevskaya, 1953 (six colonies measured). Abbreviations as for Table 1.

\begin{tabular}{lcccccc}
\hline & $\mathrm{N}$ & $\mathrm{MIN}$ & $\mathrm{MAX}$ & $\mathrm{X}$ & $\mathrm{SD}$ & $\mathrm{CV}$ \\
\hline Branch diameter, mm & 16 & 1.95 & 2.55 & 2.28 & 0.199 & 8.72 \\
Exozone width, mm & 16 & 0.37 & 0.60 & 0.46 & 0.065 & 14.22 \\
Endozone width, mm & 16 & 1.10 & 1.71 & 1.37 & 0.167 & 12.20 \\
Aperture width, mm & 25 & 0.14 & 0.25 & 0.19 & 0.029 & 14.90 \\
Aperture spacing, mm & 25 & 0.25 & 0.45 & 0.35 & 0.047 & 13.63 \\
Acanthostyle diameter, mm & 25 & 0.04 & 0.08 & 0.06 & 0.009 & 15.08 \\
Acanthostyles per aperture & 20 & 2.0 & 6.0 & 3.6 & 0.995 & 27.63 \\
Mesozooecia width, mm & 25 & 0.08 & 0.22 & 0.13 & 0.041 & 30.55 \\
Mesozooecia per aperture & 20 & 3.0 & 6.0 & 4.5 & 0.827 & 18.38 \\
Mesozooecial diaphragm & 20 & 0.02 & 0.18 & 0.11 & 0.045 & 41.02 \\
spacing, mm & & & & & & \\
Hemiphragm spacing, mm & 20 & 0.11 & 0.25 & 0.17 & 0.039 & 22.28 \\
\hline
\end{tabular}

Remarks. - Dittopora sokolovi Modzalevskaya, 1953 differs from $D$. claeviformis Dybowski, 1877 in having of branching colony instead of rod-like in the latter species, as well as in having smaller autozooecial apertures (aperture width $0.14-0.25 \mathrm{~mm}$ vs. $0.24-0.28 \mathrm{~mm}$ in D. claeviformis; measurements for D. claeviformis are from Koromyslova 2011, p. 943).

Occurrence. - Lower to Middle Ordovician of Estonia, Belarus, and Russia. Obukhovo Fm., Kunda Stage, Darriwilian, Middle Ordovician; Putilovo quarry, Russia (studied material).

Figure 10. A-H - Dittopora annulata (Eichwald, 1860); A - external view of the branched colony, GIT 852-18; B-D - branch transverse section showing autozooecial chambers, mesozooecia and acanthostyles, GIT 852-18b; E - branch longitudinal section showing autozooecial chambers, mesozooecia and acanthostyles, GIT 852-18d; F - branch longitudinal section showing hemiphragms in autozooecial chambers of early exozone (arrow), GIT 852-18d; G, H - tangential section showing autozooecial apertures, mesozooecia and acanthostyles, GIT 852-18c. Scale bars: 10 mm (A), $2 \mathrm{~mm}(\mathrm{~B}, \mathrm{E}), 1 \mathrm{~mm}(\mathrm{C}), 0.5 \mathrm{~mm}(\mathrm{D}, \mathrm{F}, \mathrm{G}), 0.2 \mathrm{~mm}(\mathrm{H})$. 

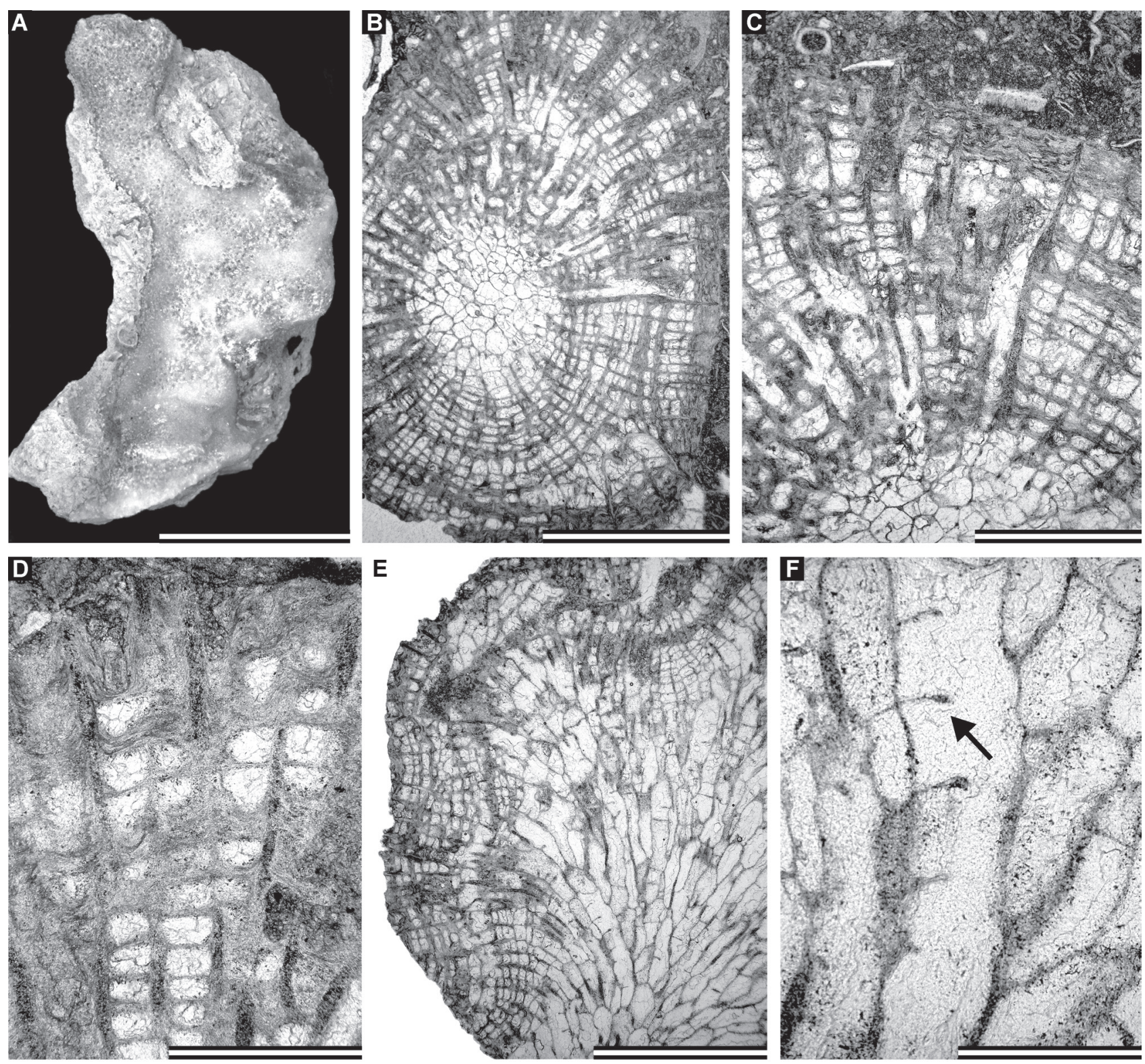

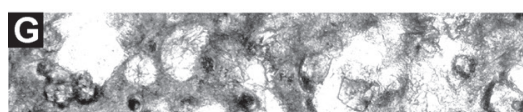

Pint

(2) 4.0 2.7.2. 3.250

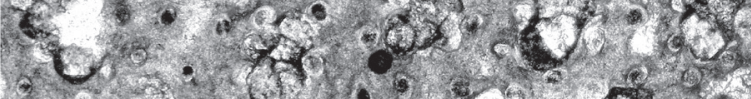

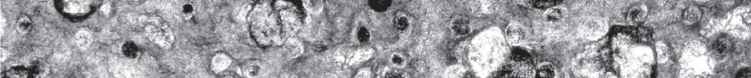

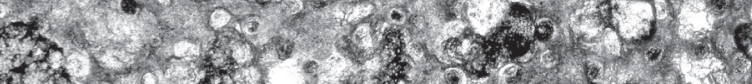

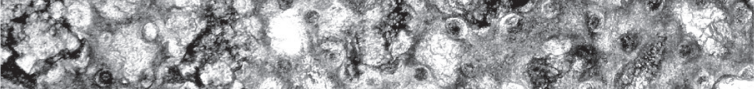
$3.12 \times 1.25$

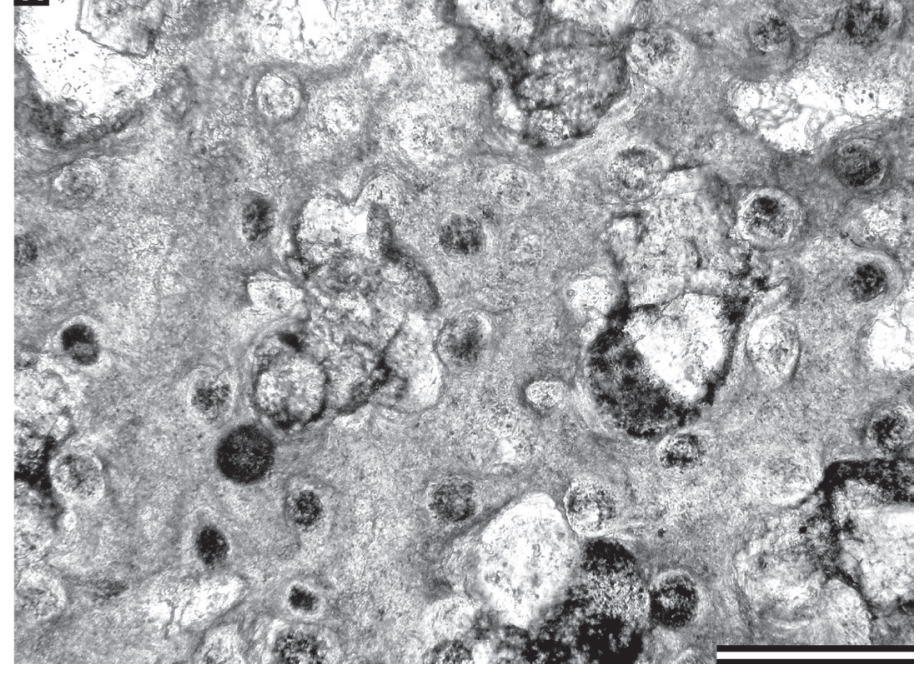




\section{Dittopora annulata (Eichwald, 1860)}

Figure 10A-H; Table 10

1860 Chaetetes annulatus Eichwald; p. 480, pl. 28, figs 2a-c, 3a-d.

1877 Dittopora anulata (Eichwald, 1860). - Dybowski, p. 86, pl. 2, fig. 5 [incorrect subsequent spelling].

1911 Dittopora annulata (Eichwald, 1860). - Bassler, pp. 304 , 305, pl. 3 , fig. 5 , pl. 11, figs 16 , 17, text-figs 186, 187.

1986 Dittopora annulata (Eichwald, 1860). - Modzalevskaya, p. 78, pl. 1, figs 8-13.

2011 Dittopora annulata (Eichwald, 1860). - Koromyslova, p. 945 , pl. 19 , figs 1,2 , pl. 20, figs $1-3$, pl. 21, figs $1-3$.

Material. - Single colony GIT 852-18a-d (four thin sections).

Table 10. Descriptive statistics of Dittopora annulata (Eichwald, 1860) (one colony measured). Abbreviations as for Table 1.

\begin{tabular}{lcccccc}
\hline & $\mathrm{N}$ & $\mathrm{MIN}$ & $\mathrm{MAX}$ & $\mathrm{X}$ & $\mathrm{SD}$ & $\mathrm{CV}$ \\
\hline Aperture width, mm & 20 & 0.13 & 0.26 & 0.20 & 0.036 & 17.48 \\
Aperture spacing, mm & 20 & 0.30 & 0.50 & 0.37 & 0.049 & 13.29 \\
Acanthostyle diameter, mm & 20 & 0.035 & 0.060 & 0.044 & 0.007 & 16.25 \\
Acanthostyles per aperture & 10 & 4.0 & 8.0 & 5.9 & 1.287 & 21.81 \\
Mesozooecia width, mm & 20 & 0.06 & 0.16 & 0.11 & 0.030 & 27.10 \\
Mesozooecia per aperture & 10 & 6.0 & 9.0 & 7.6 & 1.265 & 16.64 \\
$\begin{array}{l}\text { Mesozooecial diaphragm } \\
\text { spacing, mm }\end{array}$ & 20 & 0.08 & 0.14 & 0.11 & 0.020 & 17.75 \\
Mesozooecia width, mm & 25 & 0.08 & 0.22 & 0.13 & 0.041 & 30.55 \\
$\begin{array}{l}\text { Mesozooecia per aperture } \\
\text { Mesozooecial diaphragm }\end{array}$ & 20 & 3.0 & 6.0 & 4.5 & 0.827 & 18.38 \\
spacing, mm & 20 & 0.02 & 0.18 & 0.11 & 0.045 & 41.02 \\
\hline
\end{tabular}

Description. - Ramose bifurcating colony. Branch diameter $2.7-4.9 \mathrm{~mm}$, with $1.34-2.70 \mathrm{~mm}$ wide endozones and with $0.68-1.51 \mathrm{~mm}$ wide exozones. Secondary overgrowths common, $0.5-1.5 \mathrm{~mm}$ in thickness. Autozooecia long, having polygonal to slightly rounded cross sections in inner endozone, growing at first parallel to branch axis in endozone, and then bending gently towards exozone, increasing in diameter; bending sharply in basal exozone and decreasing in diameter; from base of exozone growing nearly perpendicular to colony surface. Autozooecial apertures oval, usually strongly petaloid due to indenting acanthostyles, opening in annulated pattern on colony surface, $13.5-16.0$ spaced in $1 \mathrm{~mm}^{2}$. Thin, straight basal diaphragms abundant in endozones; rare to absent in exozones. Hemiphragms common to abundant, concentrated in the transition between endozone and exozone. Mesozooecia abundant, polygonal in cross section, originating in endozone, bearing abundant diaphragms, 6-9 surrounding each autozooecial aperture, covered on colony surface by laminated calcitic skeleton. Acanthostyles large, prominent, abundant, possessing wide hyaline cores and thin laminated sheaths, originating at the base of exozone, deeply inflecting autozooecial living chambers, 4-8 surrounding each aperture, $59.0-60.0$ spaced in $1 \mathrm{~mm}^{2}$ of branch surface. Smaller styles sporadically present between acanthostyles, $0.020-0.025 \mathrm{~mm}$ in diameter. Autozooecial walls granular-prismatic, $0.005-0.010 \mathrm{~mm}$ thick in endozone; finely laminated, $0.05-0.11 \mathrm{~mm}$ thick in exozone. Maculae transversally annular, depressed, composed of mesozooecia and acanthostyles, $1.2-2.1 \mathrm{~mm}$ wide and spaced $2.3-3.0 \mathrm{~mm}$ from centre to centre longitudinally.

Remarks. - Pushkin (1987) placed Dittopora annulata (Eichwald, 1860) in the genus Dybowskites, whereas Gorjunova (2005) assigned it to her genus Rozhnovites. However, the type species of Rozhnovites, R. limatus Gorjunova, 2005 possesses no hemiphragms. Dittopora annulata corresponds to the diagnosis of the genus Dittopora, therefore, it is retained within this genus. It differs from Dittopora sokolovi Modzalevskaya, 1953 in having more abundant mesozooecia and acanthostyles (6-9 mesozooecia per aperture vs. 3-6 in D. sokolovi; 4-8 acanthostyles per aperture vs. 2-6 in D. sokolovi).

Occurrence. - Latorp-Kunda horizons, Floian-Darriwilian, Lower-Middle Ordovician; NW Russia. Obukhovo Fm., Kunda Stage, Darriwilian, Middle Ordovician; Putilovo quarry, Russia (studied material).

\section{Dittopora aff. annulata (Eichwald, 1860)}

Figure 11A-H, 12A-E; Table 11

Material. - Single specimen GIT 155-2045a-j (ten thin sections).

Description. - Ramose colonies with rare bifurcations. Branch diameters $3.25-4.00 \mathrm{~mm}$, with, $1.37-1.74 \mathrm{~mm}$ wide endozones and $0.81-1.13 \mathrm{~mm}$ wide exozones. Secondary overgrowths unknown. Autozooecia long,

Figure 11. A-H - Dittopora aff. annulata (Eichwald, 1860); A - branched colony imbedded in the rock, GIT 155-2045; B-F - longitudinal section, showing autozooecial chambers, mesozooecia and acanthostyles, GIT 155-2045g; G, H - transverse section showing autozooecial chambers, mesozooecia and acanthostyles, GIT 155-2045h. Scale bars: $10 \mathrm{~mm}$ (A), $2 \mathrm{~mm}$ (B), $1 \mathrm{~mm}$ (C, D, E, G, H), $0.5 \mathrm{~mm}$ (F). 

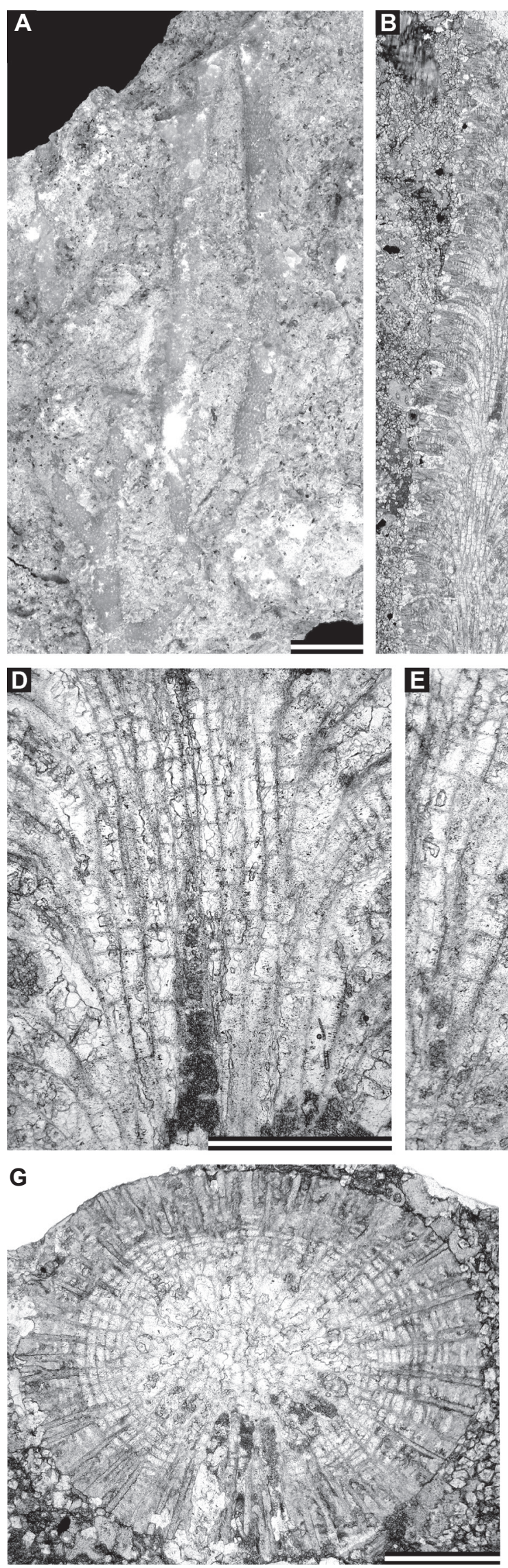

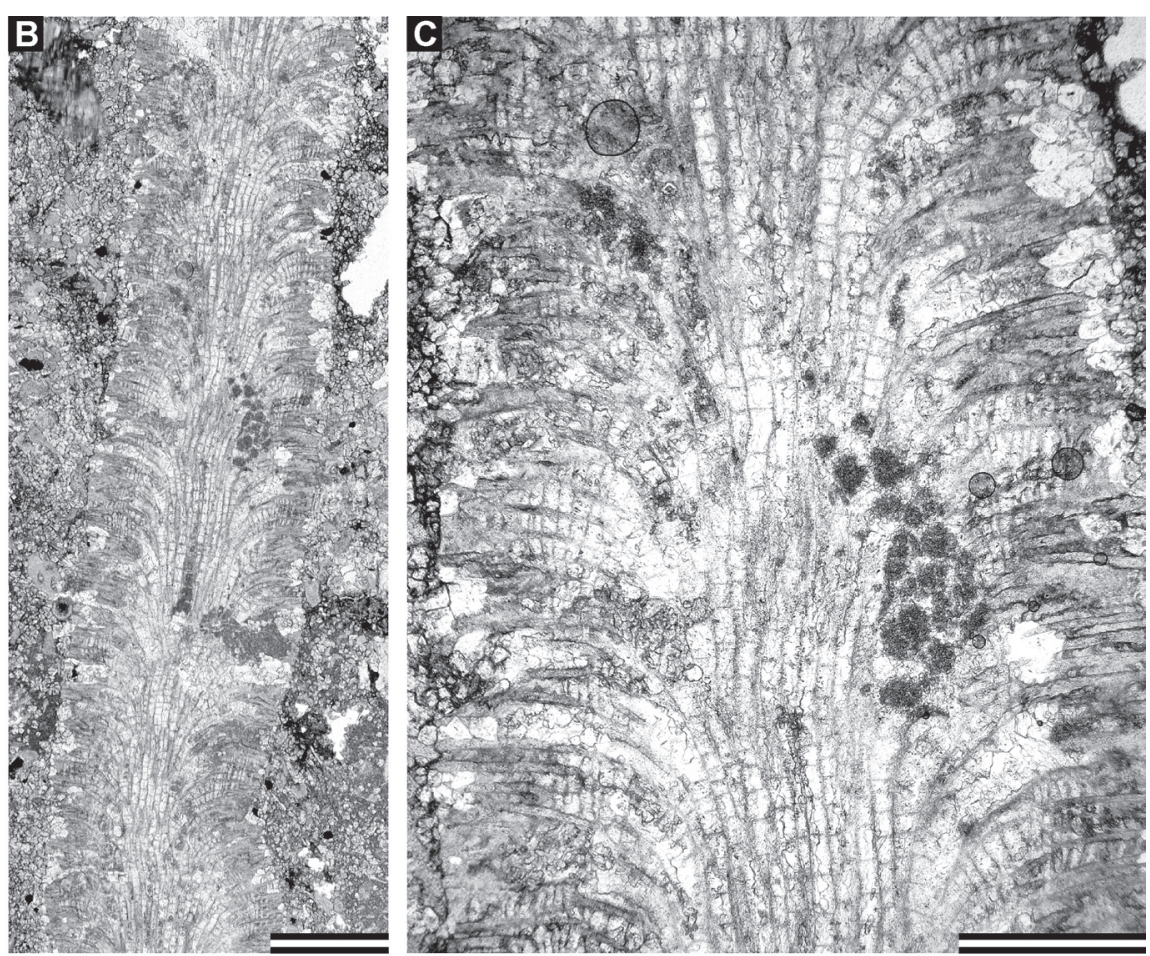

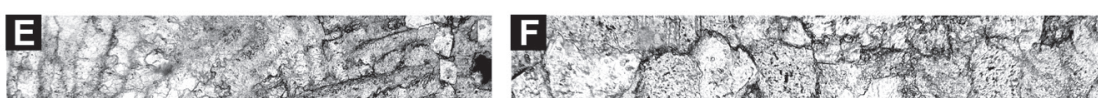
We

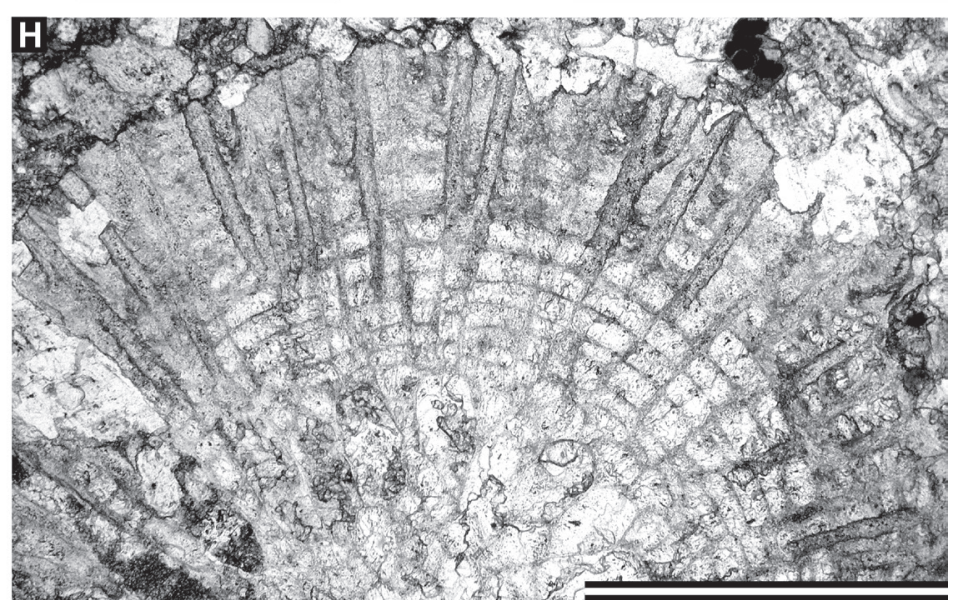


having polygonal to slightly rounded cross sections in inner endozone, growing at first parallel to branch axis in endozone, and then bending gently towards exozone, increasing in diameter; bending sharply in basal exozone and decreasing in diameter; from base of exozone growing nearly perpendicular to colony surface. Autozooecial apertures oval, usually strongly petaloid due to indenting acanthostyles, opening in annulated pattern on colony surface, $7-11$ spaced in $1 \mathrm{~mm}^{2}$. Thin, straight basal diaphragms abundant in endozones; rare to absent in exozones. Hemiphragms common to abundant, concentrated in the transition between endozone and exozone. Mesozooecia abundant, polygonal in cross section, originating deeply in endozone, bearing abundant diaphragms, 8-9 surrounding each autozooecial aperture, covered on colony surface by laminated calcitic skeleton. Acanthostyles large, prominent, abundant, possessing wide hyaline cores and thin laminated sheaths, originating at the base of exozone, deeply inflecting autozooecial living chambers, 5-11 surrounding each aperture, spaced 44-61 in $1 \mathrm{~mm}^{2}$ of branch surface. Autozooecial walls granular-prismatic, $0.005-0.010 \mathrm{~mm}$ thick in endozone; finely laminated, $0.018-0.036 \mathrm{~mm}$ thick in exozone. Smaller styles sporadically present between acanthostyles, concentrated mainly around mesozooecia, 0.025$0.035 \mathrm{~mm}$ in diameter. Maculae transversally annular, depressed, composed of mesozooecia and acanthostyles, $0.29-0.54 \mathrm{~mm}$ wide and spaced $2.1-2.3 \mathrm{~mm}$ from centre to centre longitudinally.

Table 11. Descriptive statistics of Dittopora aff. annulata (Eichwald, 1860) (one colony measured). Abbreviations as for Table 1.

\begin{tabular}{lcccccc}
\hline & $\mathrm{N}$ & $\mathrm{MIN}$ & $\mathrm{MAX}$ & $\mathrm{X}$ & $\mathrm{SD}$ & $\mathrm{CV}$ \\
\hline Aperture width, mm & 20 & 0.13 & 0.26 & 0.20 & 0.036 & 17.48 \\
Aperture spacing, mm & 20 & 0.30 & 0.50 & 0.37 & 0.049 & 13.29 \\
Acanthostyle diameter, mm & 20 & 0.035 & 0.060 & 0.044 & 0.007 & 16.25 \\
Acanthostyles per aperture & 10 & 4.0 & 8.0 & 5.9 & 1.287 & 21.81 \\
Mesozooecia width, mm & 20 & 0.06 & 0.16 & 0.11 & 0.030 & 27.10 \\
$\begin{array}{l}\text { Mesozooecia per aperture } \\
\text { Mesozooecial diaphragm }\end{array}$ & 10 & 6.0 & 9.0 & 7.6 & 1.265 & 16.64 \\
spacing, mm & 20 & 0.08 & 0.14 & 0.11 & 0.020 & 17.75 \\
\hline
\end{tabular}

Remarks. - The present material is superficially similar to Dittopora annulata (Eichwald, 1860) (see above). However, it has smaller autozooecia (aperture width $0.13 \mathrm{~mm}$ vs. $0.20 \mathrm{~mm}$ in $D$. annulata), as well as more abundant and larger acanthostyles (7-11 acanthostyles per aperture vs. 4-8 in D. annulata; average acanthostyle diameter $0.070 \mathrm{~mm} v s .0 .044 \mathrm{~mm}$ in $D$. annulata). As far as only one colony is available, this species is described in the open nomenclature.
Occurrence. - Kunda Stage, Darriwilian, Middle Ordovician; Väike-Pakri cliff, Estonia.

\section{Genus Hemiphragma Ulrich, 1893}

Type species. - Batostoma irrasum Ulrich, 1886. Middle Ordovician (Trenton); North America.

Diagnosis. - Colonies massive and ramose. Autozooecia with polygonal and polygonal-rounded apertures. Autozooecial diaphragms present. Hemiphragms occurring throughout autozooecial chambers. Autozooecial walls in exozone strongly thickened, partly integrated, displaying sloped and longitudinally lamellar microstructure. Mesozooecia usually rare, but sometimes abundant. Acanthostyles usually small and rare, but sometimes abundant.

Remarks. - Hemiphragma Ulrich, 1893 is most similar to Phragmopora Vinassa de Regny, 1921, differing in having acanthostyles and smaller mesozooecia.

Occurrence. - Lower to Middle Ordovician; North America, Europe, Siberia.

\section{Hemiphragma rotundatum Bassler, 1911}

Figure 12F-H, 13A-C; Table 12

1911 Hemiphragma rotundatum Bassler, pp. 294, 295, textfig. 180.

1986 Hemiphragma rotundatum Bassler, 1911. - Modzalevskaya, pp. 82, 83, pl. 2, figs 4,5 .

Material. - Single specimen GIT 155-287a-d (four thin sections).

Table 12. Descriptive statistics of Hemiphragma rotundatum Bassler, 1911 (one colony measured). Abbreviations as for Table 1.

\begin{tabular}{lcccccc}
\hline & $\mathrm{N}$ & $\mathrm{MIN}$ & $\mathrm{MAX}$ & $\mathrm{X}$ & $\mathrm{SD}$ & $\mathrm{CV}$ \\
\hline Aperture width, mm & 20 & 0.25 & 0.32 & 0.28 & 0.019 & 6.79 \\
Aperture spacing, mm & 20 & 0.30 & 0.50 & 0.37 & 0.056 & 15.19 \\
Acanthostyle diameter, mm & 20 & 0.030 & 0.065 & 0.047 & 0.009 & 18.86 \\
Acanthostyles per aperture & 10 & 6.0 & 10.0 & 8.0 & 1.155 & 14.43 \\
Mesozooecia width, mm & 20 & 0.05 & 0.12 & 0.09 & 0.021 & 22.80 \\
Mesozooecia per aperture & 10 & 3.0 & 7.0 & 4.7 & 1.252 & 26.63 \\
$\begin{array}{l}\text { Mesozooecial diaphragm } \\
\text { spacing, mm }\end{array}$ & 20 & 0.07 & 0.15 & 0.10 & 0.020 & 19.74 \\
Hemiphragm spacing, mm & 20 & 0.12 & 0.22 & 0.15 & 0.029 & 18.65 \\
\hline
\end{tabular}

Description. - Globular multilayered colony in size of $14 \times 18 \mathrm{~mm}$. Separate layers $1.7-4.7 \mathrm{~mm}$ in thickness. 

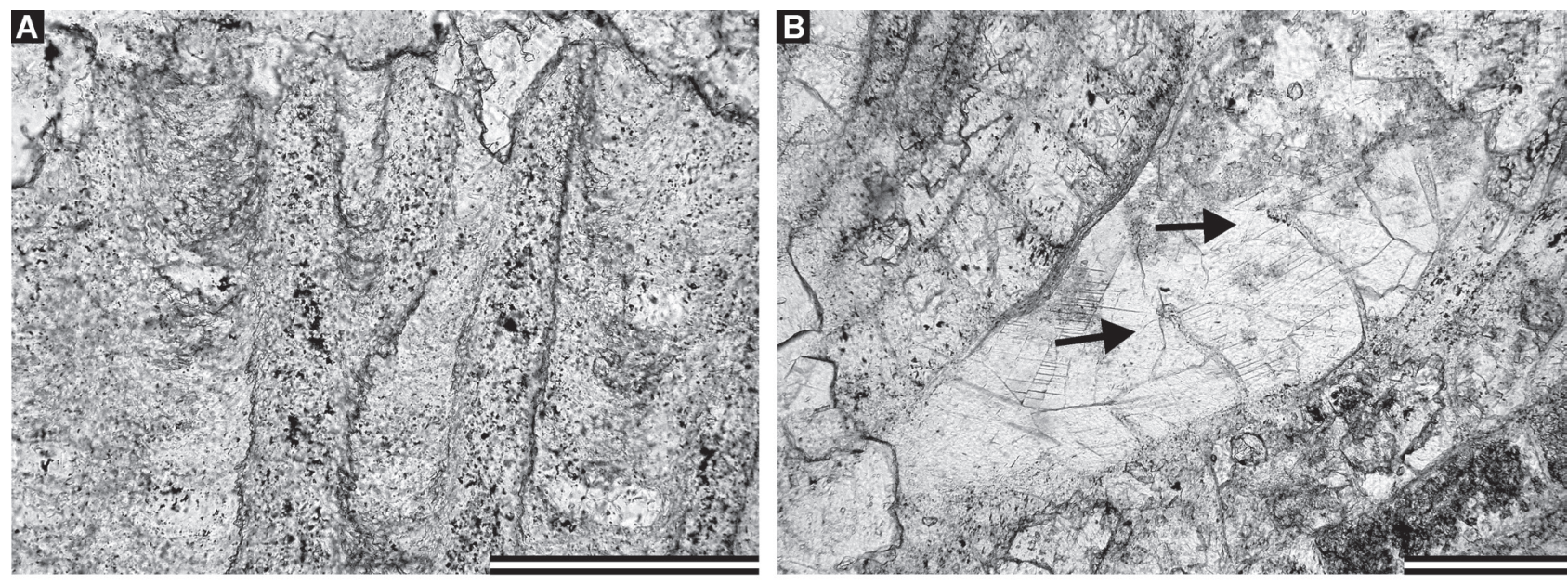
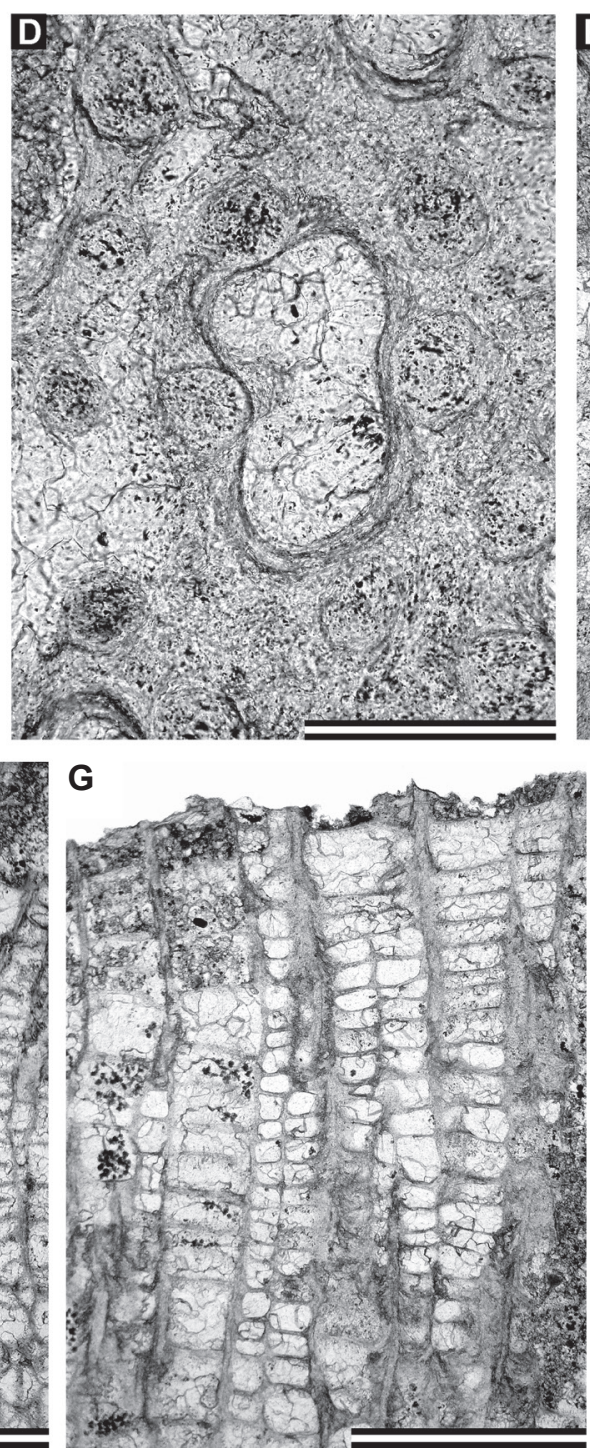
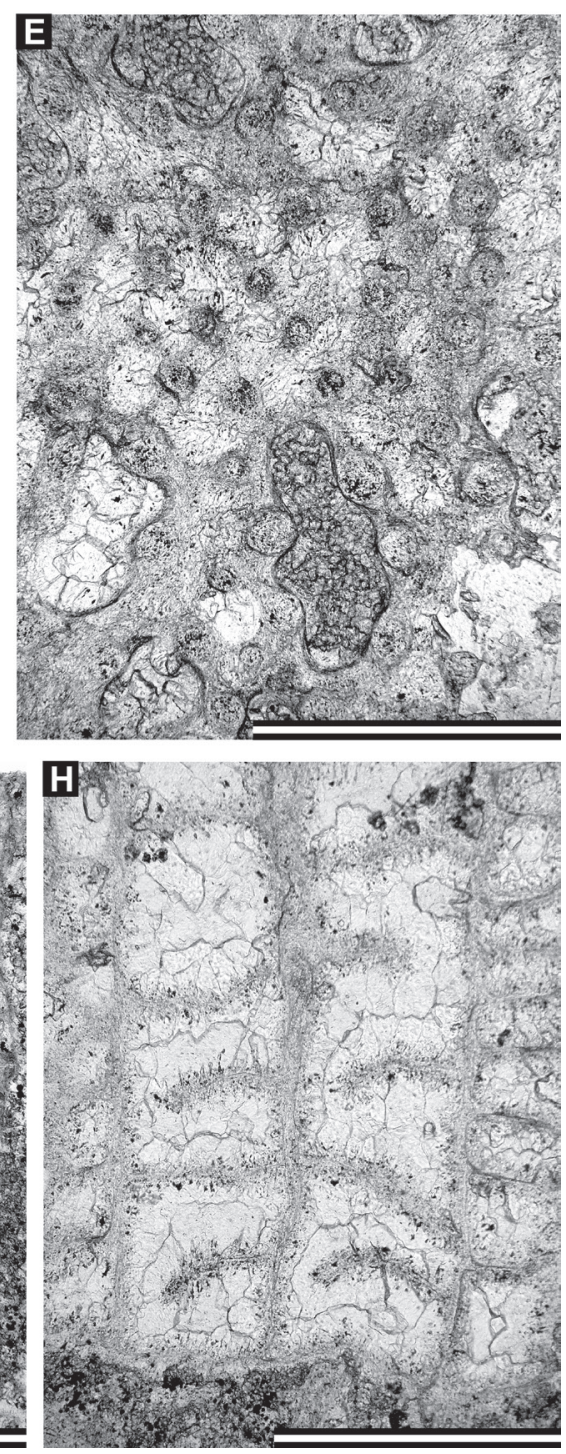

Figure 12. A-E - Dittopora aff. annulata (Eichwald, 1860); A - transverse section showing autozooecial chambers, mesozooecia and acanthostyles, GIT 155-2045h; B - longitudinal section, showing autozooecial chambers with hemiphragms (arrows), GIT 155-2045d; C-E - tangential section showing autozooecial apertures, mesozooecia and acanthostyles (E - macula composed of mesozooecia and acanthostyles), GIT 155-2045i. • F-H Hemiphragma rotundatum Bassler, 1911, longitudinal section showing autozooecial chambers with hemiphragms and mesozooecia, GIT 155-287b. Scale bars: $1 \mathrm{~mm}(\mathrm{~F}, \mathrm{G}), 0.5 \mathrm{~mm}(\mathrm{C}, \mathrm{E}, \mathrm{H}), 0.2 \mathrm{~mm}(\mathrm{~A}, \mathrm{~B}, \mathrm{D})$. 
Exozones indistinct. Autozooecia long, prismatic, budding from a thin epitheca. autozooecial apertures rounded-polygonal to petaloid, 7-9 spaced per $1 \mathrm{~mm}^{2}$. Hemiphragms most abundant throughout the colony, long and thick, curved to proximal end on their inner edge. Basal diaphragms few to absent. Mesozooecia large, abundant, 3-7 surrounding each autozooecial aperture and 10-14 spaced per $1 \mathrm{~mm}^{2}$. Acanthostyles abundant, 6-10 surrounding each autozooecial aperture and 22-32 spaced per $1 \mathrm{~mm}^{2}$, having distinct hyaline cores and wide laminated sheaths. Walls straight, displaying hyaline microstructure, $0.005-0.010 \mathrm{~mm}$ thick in endozone; laminated, integrated, $0.03-0.05 \mathrm{~mm}$ thick in exozone. Indistinct maculae consisting of larger autozooecia present.

Remarks. - Hemiphragma rotundatum Bassler, 1911 differs from H. pygmeum Bassler, 1911 from the Upper Ordovician of Estonia and Sweden in larger autozooecia (aperture width $0.25-0.32 \mathrm{~mm} v s .0 .15-0.25 \mathrm{~mm}$ in H. pygmeum). Hemiphragma rotundatum differs from H. insolitum Koromyslova \& Fedorov, 2021 from the Middle Ordovician (Dapingian) of Russia in its globular colony instead of encrusting one and in having smaller mesozooecia (average mesozooecial width $0.09 \mathrm{~mm} v s$. $0.15 \mathrm{~mm}$ in $H$. insolitum).

Occurrence. - Lower-Middle Ordovician of Estonia and NW Russia. Kunda Stage, Darriwilian, Middle Ordovician; Väike-Pakri cliff, Estonia (present material).

Family Mesotrypidae Astrova, 1965

\section{Genus Mesotrypa Ulrich, 1893}

Type species. - Diplotrypa infida Ulrich, 1886. Middle Ordovician, North America.

Diagnosis. - Massive, hemispheric, conical or discoidal colonies. Autozooecial apertures polygonal or rounded. Walls thin, longitudinally laminated, indistinctly separated. Diaphragms planar, sloped, curved, and funnelshaped. Mesozooecia abundant, budding from base of colony. Acanthostyles may be large, growing from the base of colony, or small, visible at colony surface.

Remarks. - Mesotrypa Ulrich, 1893 differs from Diazipora Vinassa de Regny, 1921 by having acanthostyles and larger mesozooecia.

Occurrence. - Middle Ordovician to lower Silurian, worldwide.

Mesotrypa bystrowi Modzalevskaya, 1953

Figure 13D-G; Table 13
For full synonymy see Pushkin (2002, p. 428).

Material. - Single colony GIT 155-2055a-c (three thin sections).

Table 13. Descriptive statistics of Mesotrypa bystrovi Modzalevskaya, 1953 (one colony measured). Abbreviations as for Table 1.

\begin{tabular}{|c|c|c|c|c|c|c|}
\hline & $\mathrm{N}$ & MIN & MAX & $X$ & SD & $\mathrm{CV}$ \\
\hline Aperture width, mm & 20 & 0.23 & 0.31 & 0.27 & 0.023 & 8.54 \\
\hline Aperture spacing, mm & 20 & 0.28 & 0.40 & 0.33 & 0.032 & 9.49 \\
\hline Mesozooecia width, mm & 20 & 0.05 & 0.18 & 0.11 & 0.040 & 35.43 \\
\hline Mesozooecia per aperture & 10 & 5.0 & 7.0 & 6.1 & 0.876 & 14.35 \\
\hline $\begin{array}{l}\text { Mesozooecial diaphragm } \\
\text { spacing, mm }\end{array}$ & 20 & 0.03 & 0.09 & 0.06 & 0.016 & 27.57 \\
\hline $\begin{array}{l}\text { Zooecial diaphragm } \\
\text { spacing, mm }\end{array}$ & 20 & 0.15 & 0.48 & 0.28 & 0.100 & 35.45 \\
\hline
\end{tabular}

Description. - Discoidal hemispheric colony with short endozones, $16 \mathrm{~mm}$ wide at its base and $10 \mathrm{~mm}$ high in its central part. Secondary overgrowths not observed. Autozooecia bending gently from epitheca, radiating from colony centre to periphery. Autozooecial apertures polygonal, 7.6-9.5 spaced per $1 \mathrm{~mm}^{2}$. Autozooecial diaphragms abundant, thin, planar or curved. Mesozooecia large, abundant, 5-7 surrounding each autozooecial aperture and 22-31.5 spaced per $1 \mathrm{~mm}^{2}$, polygonal in cross section, originating at the base of colony, bearing straight closely spaced diaphragms. Autozooecial walls finely laminated, $0.003-0.008 \mathrm{~mm}$ thick. Acanthostyles indistinct, spine-like, $0.025-0.035 \mathrm{~mm}$ in diameter, positioned in junctions between apertures. Maculae not observed.

Remarks. - Mesotrypa bystrowi Modzalevskaya, 1953 differs from M. egena Bassler, 1911 from the Upper Ordovician of Estonia and Norway in having smaller autozooecial apertures (average aperture width $0.27 \mathrm{~mm}$ vs. $0.30 \mathrm{~mm}$ in M. egena; measurements from Ernst \& Nakrem 2012) and more abundant mesozooecia (5-7 per aperture $v$ s. 2-6 in M. egena).

Occurrence. - Middle to Upper Ordovician of Estonia and NW Russia (Pushkin 2002, p. 430). Kunda Stage, Darriwilian, Middle Ordovician; Harku Quarry, Estonia (present material).

Family Bimuroporidae Key, 1990

\section{Genus Sonninopora Vinassa de Regny, 1921}

Type species. - Hallopora tenuispinosa Bassler, 1911. Ordovician (Sandbian-Katian); Estonia. 

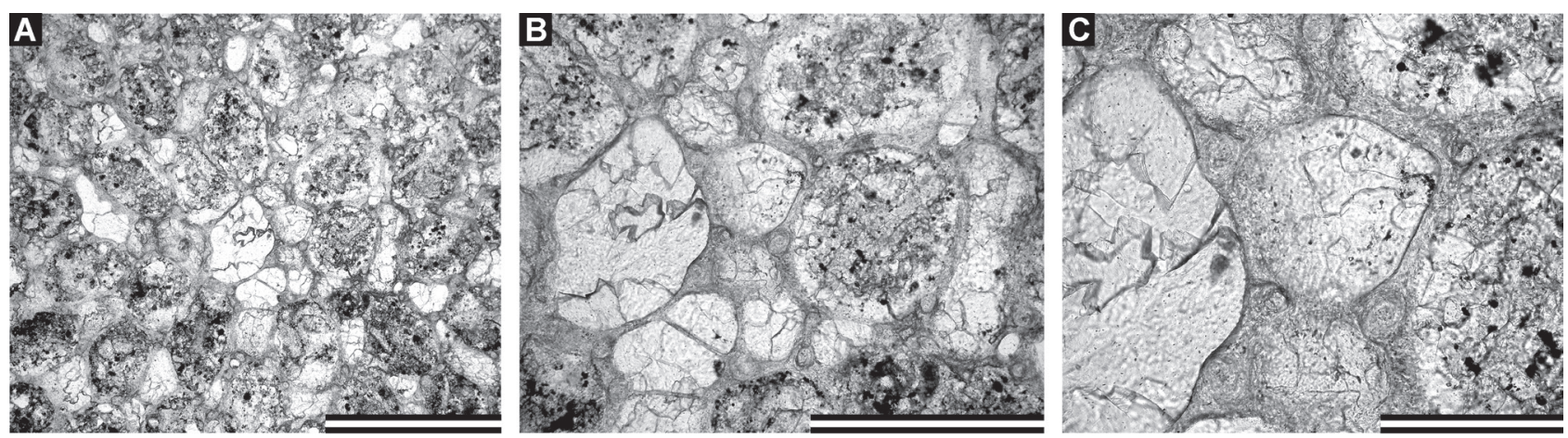

D
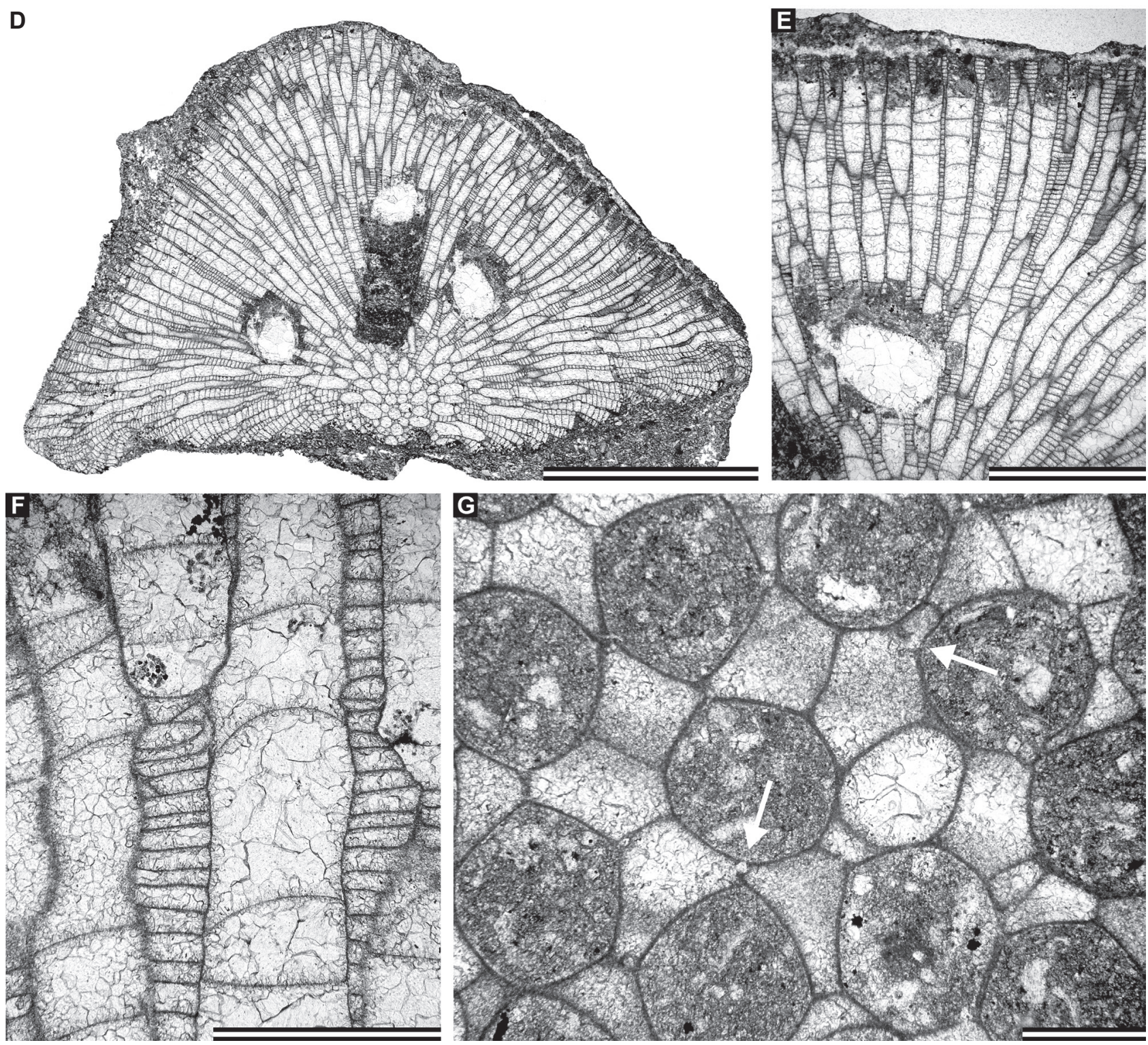

Figure 13. A-C - Hemiphragma rotundatum Bassler, 1911, tangential section showing autozooecial apertures, acanthostyles, and mesozooecia, GIT 155-287c. • D-G - Mesotrypa bystrowi Modzalevskaya, 1953; D - longitudinal section of a hemispheric colony with borings, GIT 155-2055b; E, F - longitudinal section showing autozooecial chambers with diaphragms and mesozooecia, GIT 155-2055b; G - tangential section tangential section showing autozooecial apertures, acanthostyles, and mesozooecia, GIT 155-2055c. Scale bars: $5 \mathrm{~mm}$ (D), $2 \mathrm{~mm}$ (E), $1 \mathrm{~mm}$ (A), $0.5 \mathrm{~mm}$ (B, F), $0.2 \mathrm{~mm}(\mathrm{C}, \mathrm{G})$. 
Diagnosis. - Colonies ramose or encrusting. Branches circular in transverse section. Zooecial budding disordered when almost all zooecia beginning their ontogeny as mesozooecia and expand into autozooecia. Autozooecial walls in endozone straight, autozooecial walls thin and integrate in exozone, boundary irregular; mesozooecial walls in endozone fluted, mesozooecia common in exozone, almost completely surrounding autozooecia; exozonal acanthostyles with cores of clear calcite. Mural spines, cap-like apparati (sensu Conti \& Serpagli 1987) absent. Maculae composed of macrozooecia and mesozooecia (modified after Key 1990).

Remarks. - Sonninopora Vinassa de Regny, 1921 differs from Bimuropora Key, 1990 in having thinner exozonal walls and more abundant mesozooecia. Sonninopora differs from Champlainopora Ross, 1970 in having an unordered zooecial arrangement without long, large axial zooecia, and more abundant mesozooecia.

Occurrence. - Ordovician (Darriwilian-Katian); Estonia, Canada.

\section{Sonninopora sp.}

Figure 14A-F; Table 14

Material. - Single specimen GIT 155-2051b, c, e, f (four thin sections).

Table 14. Descriptive statistics of Sonninopora sp. (one colony measured). Abbreviations as for Table 1.

\begin{tabular}{lcccccc}
\hline & $\mathrm{N}$ & $\mathrm{MIN}$ & $\mathrm{MAX}$ & $\mathrm{X}$ & $\mathrm{SD}$ & $\mathrm{CV}$ \\
\hline Aperture width, mm & 20 & 0.18 & 0.32 & 0.26 & 0.038 & 14.71 \\
Aperture spacing, mm & 20 & 0.23 & 0.42 & 0.32 & 0.062 & 19.52 \\
Acanthostyle diameter, mm & 20 & 0.025 & 0.040 & 0.032 & 0.003 & 10.18 \\
Acanthostyles per aperture & 9 & 4.0 & 7.0 & 5.3 & 1.000 & 18.75 \\
Mesozooecia width, mm & 20 & 0.05 & 0.15 & 0.09 & 0.029 & 31.37 \\
Mesozooecia per aperture & 10 & 4.0 & 8.0 & 6.5 & 1.581 & 24.33 \\
Mesozooecial diaphragm & 20 & 0.06 & 0.11 & 0.09 & 0.015 & 16.91 \\
spacing, mm & & & & & & \\
Hemiphragm spacing, mm & 20 & 0.12 & 0.22 & 0.15 & 0.029 & 18.65 \\
\hline
\end{tabular}

Description. - Subramose colony (incomplete), ca $7.4 \mathrm{~mm}$ wide, with indistinct exozone. Basal diaphragms uncommon, $1-2$ in each autozooecium. Autozooecia long, originating mostly from mesozooecia. Autozooecial apertures rounded-polygonal, $12-13$ spaced per $1 \mathrm{~mm}^{2}$. Mesozooecia moderate in size, abundant, 4-8 surrounding each autozooecial aperture and 22-28 spaced per $1 \mathrm{~mm}^{2}$, slightly beaded, bearing abundant straight and rarely inclined diaphragms. Acanthostyles abundant, 4-7 surrounding each autozooecial aperture, having distinct hyaline cores and wide laminated sheaths. Walls straight, displaying hyaline microstructure, $0.005-0.008 \mathrm{~mm}$ thick in endozone; laminated, integrated, $0.018-0.036 \mathrm{~mm}$ thick in exozone. Maculae not observed in the studied material. Vesicular skeleton at the base of the colony present.

Remarks. - The present material is similar to Sonninopora tenuispinosa (Bassler, 1911) from the Upper Ordovician (Sandbian-Katian) of Estonia. It has eventually smaller autozooecial apertures. Bassler (1911) and Key \& Judd (1994) did not provide measurements of apertures of the type material of Hallopora tenuispinosa Bassler, 1911. Measured aperture widths from the text-fig. 213 of Bassler (1911) gave values of $0.30-0.40 \mathrm{~mm} v s .0 .18-0.32 \mathrm{~mm}$ in present material. Key \& Judd (1994, p. 236) gave the number of mesozooecia per $1 \mathrm{~mm}^{2}$ as $7.3-14.4$ vs. 22-28 in the present material.

Occurrence. - Kunda Stage, Darriwilian, Middle Ordovician; Harku quarry, Estonia.

Family uncertain

\section{Genus Pakripora gen. nov.}

Type species. - Pakripora cavernosa sp. nov.

Etymology. - The new genus is named after finding it at Pakri, Estonia.

Diagnosis. - Ramose colonies with distinct exozones and secondary overgrowths; autozooecia polygonal in exozone, containing abundant diaphragms; short and blunt mural spines in autozooecial walls of chambers in exozone; mesozooecia abundant; acanthostyles abundant, with distinct wide hyaline cores and narrow laminated sheaths; maculae common, slightly depressed, composed of mesozooecia and acanthostyles.

Remarks. - The new genus is characterized by abundant acanthostyles and mesozooecia, as well as by the presence of mural spines in autozooecia. Männil (1959, pp. $317-$ 319) established the species Leioclema? pakrianum. The genus Leioclema Ulrich, 1882 differs from the new genus in having rare to absent diaphragms in autozooecia as well as in absence of mural spines in autozooecia. Moreover, acanthostyles in Leioclema possess distinct narrow hyaline cores and wide laminated sheaths (Tavener-Smith 1969).

Mural spines of similar morphology are present in the genus Stenoporella Bassler, 1936 from the Carboniferous of USA. However, Stenoporella belongs to the Suborder Amplexoporina Astrova, 1965 and develops exilazooecia 

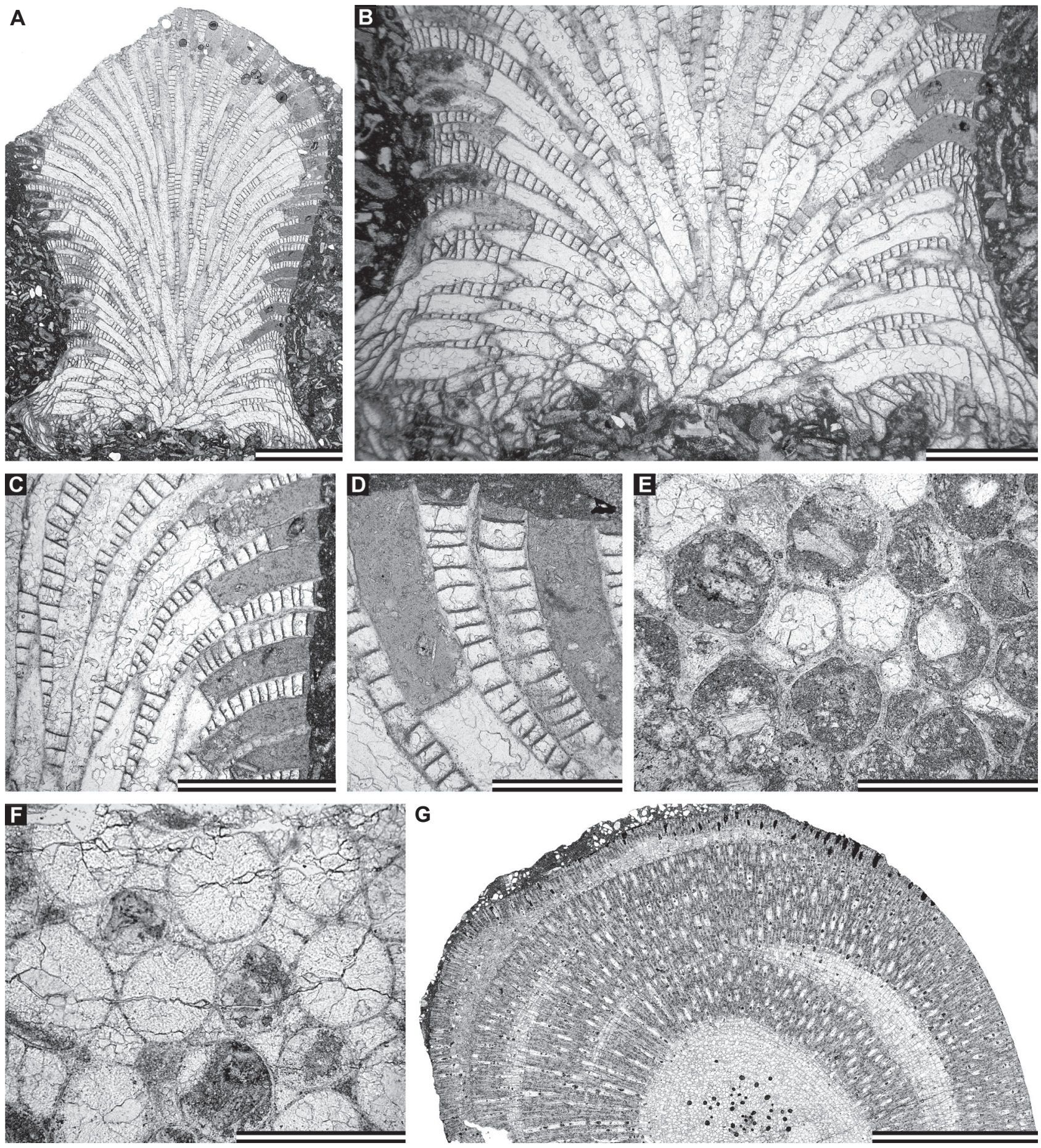

Figure 14. A-F - Sonninopora sp.; A-D - longitudinal section showing autozooecial chamber, mesozooecia and acanthostyles, GIT 155-2051e; E, F - tangential section showing autozooecial apertures, acanthostyles and mesozooecia, GIT 155-2051f. • G - Pakripora cavernosa gen. et sp. nov., transverse section showing endozone and exozone, holotype GIT 537-2265c. Scale bars: $5 \mathrm{~mm}(\mathrm{G}), 2 \mathrm{~mm}(\mathrm{~A}), 1 \mathrm{~mm}(\mathrm{~B}, \mathrm{C}), 0.5 \mathrm{~mm}(\mathrm{D}-\mathrm{F})$.

instead of mesozooecia, and possesses typical acanthostyles known in the Family Stenoporidae, with distinct narrow hyaline cores and wide laminated sheaths.

Occurrence. - Kunda Stage, Darriwilian, Middle Ordovician; Väike-Pakri island, Paldiski, Estonia.
Pakripora cavernosa sp. nov.

Figure 14G; 15A-H; 16A, B; Table 15

Holotype. - GIT 537-2265a-h (eight thin sections), originally assigned to Leioclema pakrianum Männil, 1959 (unpublished). 
Table 15. Descriptive statistics of Pakripora cavernosa gen. et sp. nov. (two colonies measured). Abbreviations as for Table 1.

\begin{tabular}{lcccccc}
\hline & $\mathrm{N}$ & $\mathrm{MIN}$ & $\mathrm{MAX}$ & $\mathrm{X}$ & $\mathrm{SD}$ & $\mathrm{CV}$ \\
\hline Aperture width, mm & 20 & 0.08 & 0.13 & 0.11 & 0.011 & 10.04 \\
Aperture spacing, mm & 20 & 0.24 & 0.35 & 0.28 & 0.026 & 9.29 \\
Acanthostyle diameter, mm & 20 & 0.04 & 0.06 & 0.05 & 0.006 & 12.32 \\
Acanthostyles per aperture & 20 & 4.0 & 7.0 & 4.8 & 0.768 & 16.00 \\
Mesozooecia width, mm & 20 & 0.040 & 0.075 & 0.060 & 0.009 & 16.57 \\
Mesozooecia per aperture & 20 & 7.0 & 9.0 & 8.0 & 0.686 & 8.63 \\
$\begin{array}{l}\text { Mesozooecial diaphragm } \\
\text { spacing, mm }\end{array}$ & 20 & 0.06 & 0.11 & 0.09 & 0.015 & 16.91 \\
Hemiphragm spacing, mm & 20 & 0.12 & 0.22 & 0.15 & 0.029 & 18.65 \\
\hline
\end{tabular}

Paratypes. - GIT 155-2047a-b (two thin sections) from the Kunda Stage of the Väike-Pakri cliff. Unstudied material includes some more specimens deposited in the collection at the GIT. Specimens GIT 537-1227 and GIT 537-1308 come from the type locality Väike-Pakri island. The sample GIT 537-1227 consists of six large fragments which may represent remnants of two colonies (Ursula Toom, pers. comm. 2021). The specimen GIT 537-2266 comes from the Kunda Stage of Paldiski (locality opposite to the Väike-Pakri island). The holotype of Männil for Leioclema pakrianum Männil, 1959, GIT 537-1232 is missing from the collection (Ursula Toom, personal communication 2021), as well as the sample GIT 537-1242, which was assigned to this species. The specimen GIT 537-1301 was originally assigned by Männil (1959) to Leioclema pakrianum, but seems to represent another species.

Type horizon and locality. - Kunda Stage, Darriwilian, Middle Ordovician; Väike-Pakri island, Estonia.

Material. - Types only.

Etymology. - The species is named after presence of abundant mesozooecia (from the Latin "cavernosa" pitted, porous).

Diagnosis. - Large ramose colonies with distinct exozones and secondary overgrowths; basal diaphragms straight, abundant; short and blunt mural spines in autozooecial walls of chambers in exozone; mesozooecia moderate in size, abundant, 7-9 surrounding each autozooecial aperture; mesozooecial diaphragms abundant, thickened in exozones almost sealing mesozooecia; acanthostyles abundant, 4-7 surrounding each autozooecial aperture; macrozooecia few near maculae; maculae common, slightly depressed, composed of mesozooecia and acanthostyles.

Description. - Ramose colonies, frequently dichotomizing. Branches $11-20 \mathrm{~mm}$ in diameter, with $5.1-7.6 \mathrm{~mm}$ wide endozones and $2.0-5.3 \mathrm{~mm}$ wide exozones. Secondary overgrowth common, $1.0-1.9 \mathrm{~mm}$ in thickness. Autozooecia long, polygonal in transverse section of endozone, bending abruptly in exozone. Basal diaphragms straight, abundant, concentrated in the transition between endozone and exozone. Mural spines in exozone, blunt, $0.025-0.050 \mathrm{~mm}$ in diameter and $0.030-0.055 \mathrm{~mm}$ long, spaced in alternating pattern (Fig. 15C-E). Autozooecial apertures rounded to petaloid, $11-15$ spaced per $1 \mathrm{~mm}^{2}$. Mesozooecia moderate in size, abundant, 7-9 surrounding each autozooecial aperture, originating deeply in endozone and containing abundant diaphragms in their endozonal parts and in the transition to exozone; in exozones mesozooecial diaphragms thickened almost sealing the mesozooecia. Acanthostyles abundant, 4-7 surrounding each autozooecial aperture, having distinct hyaline cores and wide laminated sheaths, originating at the base of exozone, indenting autozooecia and mesozooecia. Autozooecial walls straight, displaying hyaline microstructure, $0.005-0.010 \mathrm{~mm}$ thick in endozone; laminated, integrated, $0.04-0.12 \mathrm{~mm}$ thick in exozone. Mesozooecial walls $0.008-0.010 \mathrm{~mm}$ thick. Macrozooecia few, occurring near maculae, $0.16-0.21 \mathrm{~mm}$ in width. Maculae common, slightly depressed, composed of mesozooecia and acanthostyles, $0.55-0.85 \mathrm{~mm}$ in diameter, spaced $2.5-3.0 \mathrm{~mm}$ from centre to centre. Fossilized brown deposited abundant, representing accumulations of irregularly rounded brown to black particles, normally concealed between two neighbouring diaphragms (Fig. 15A-C, E, F). Particles in brown deposits $0.005-0.025 \mathrm{~mm}$ in diameter.

Remarks. - According to the rules of the Zoological Nomenclature, the species Leioclema pakrianum established by Männil in his dissertation (1959) is not valid. Therefore, his material has been used to erect a new species.

Order Cryptostomata Vine, 1884

Suborder Ptilodictyina Astrova \& Morozova, 1956

Figure 15. A-H - Pakripora cavernosa gen. et sp. nov.; A - transverse section showing endozone and exozone, holotype GIT 537-2265c; B-E - transverse section showing zooecial chambers with brown deposits, diaphragms, and mural spines (arrows), holotype GIT 537-2265d; F - transverse section showing zooecial chambers showing zooecial chambers and mesozooecia at the base of exozone, holotype GIT 537-2265e; $\mathrm{G}, \mathrm{H}$ - tangential section showing autozooecial apertures, acanthostyles, mesozooecia, and a macula composed of acanthostyles and mesozooecia (centred), holotype GIT 537-2265g. Scale bars: $1 \mathrm{~mm}$ (A, G), $0.5 \mathrm{~mm}$ (B, F), $0.2 \mathrm{~mm}$ (C, E, H), $0.1 \mathrm{~mm}$ (D). 

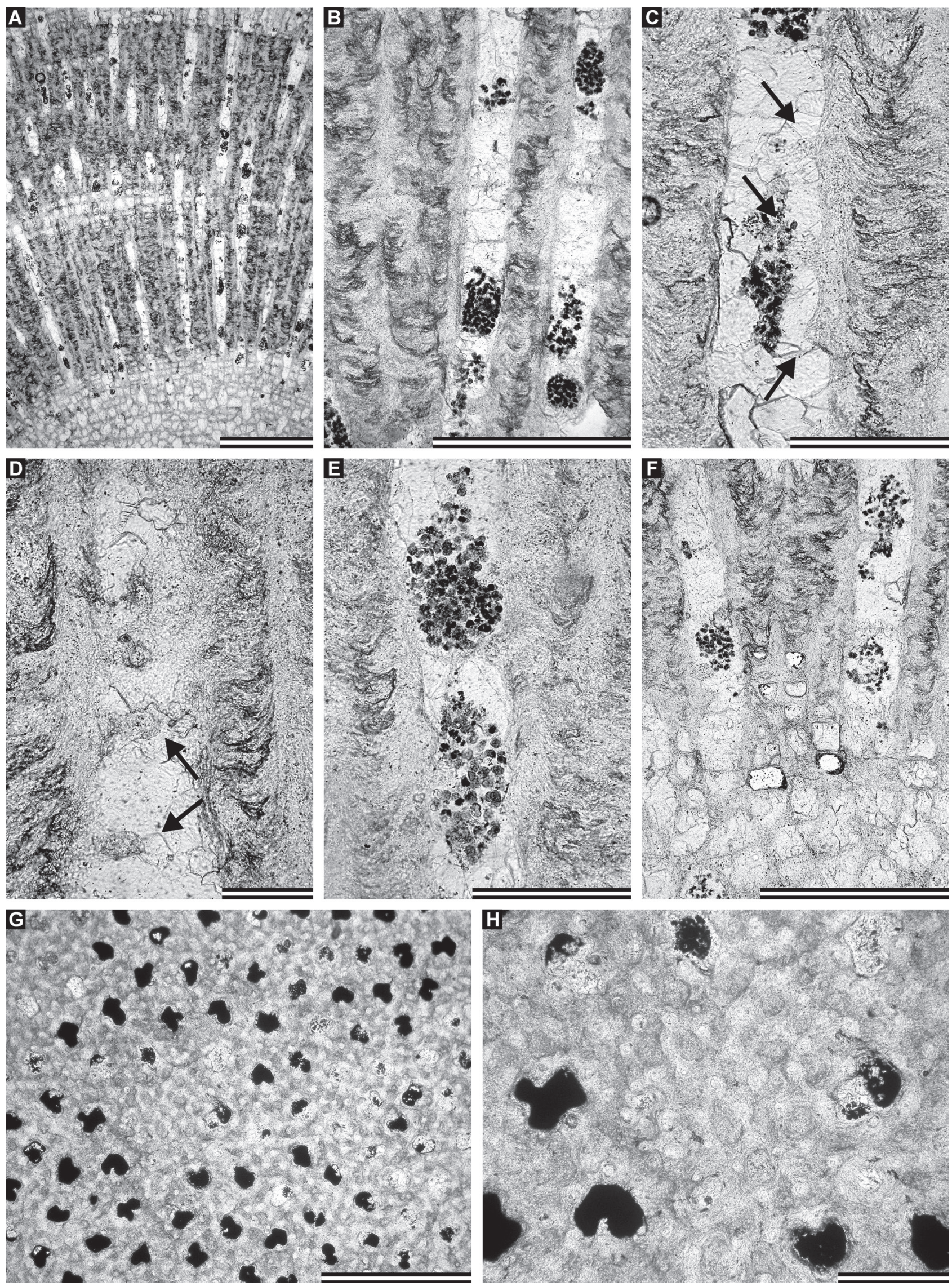


\section{Genus Prophyllodictya Gorjunova, 1987 in Gorjunova \& Lavrentjeva (1987)}

Type species. - Prophyllodictya intermedia Gorjunova, 1987 in Gorjunova \& Lavrentjeva (1987). Ordovician, Floian (Volkhov horizon $\mathrm{B}_{\mathrm{II} \gamma}$ ); Maardu, Estonia.

Diagnosis. - Colonies erect, lenticular, frondose or reticulate; branches oval or lens-shaped in transversal section; mesotheca straight, without hyaline rods; autozooecia long, tubular, bending in exozone; diaphragms rare or absent; hemisepta absent; autozooecial apertures oval, arranged in alternating rows on the colony surface; low ridges between apertures bearing paurostyles present; exozonal tubes present; maculae lacking autozooecia and bearing paurostyles and exozonal tubes occurring.

Remarks. - Prophyllodictya Gorjunova, 1987 in Gorjunova \& Lavrentjeva (1987) differs from Phyllodictya Ulrich, 1882 in absence of hyaline rods in mesotheca and presence of exozonal tubes.

Occurrence. - Lower Ordovician (Tremadocian)-Upper Ordovician (Katian); China, Estonia, Russia, Spain.

\section{Prophyllodictya intermedia Gorjunova, 1987 in Gorjunova \& Lavrentjeva (1987)}

Figure $16 \mathrm{C}-\mathrm{F}, 17 \mathrm{~A}-\mathrm{C}$

1987 Prophyllodictya intermedia Gorjunova; Gorjunova \& Lavrentjeva, p. 47, pl. 5, fig. 1, text-figs 1-3.

1993 Prophyllodictya intermedia Gorjunova, 1987. Gorjunova \& Lavrentjeva, p. 38, pl. 1, figs 1, 2.

1996 Prophyllodictya intermedia Gorjunova, 1987. Gorjunova, pl. 35, fig. 1.

Material. - Two samples GIT 852-4a-b and GIT 852-8a (three thin sections).

Description. - Erect colony consisting of flat branches, $2.75 \mathrm{~mm}$ wide and $1.20-1.25 \mathrm{~mm}$ thick. Mesotheca straight, $0.015-0.020 \mathrm{~mm}$ in thickness. Long, tubular autozooecia, sharply bending in inner exozone. Autozooecial diaphragms rare. Autozooecial apertures oval, arranged in 13 alternating rows. Paurostyles between apertures in one row, $0.025-0.040 \mathrm{~mm}$ in diameter. Locally exozonal tubes present, $0.02-0.03 \mathrm{~mm}$ in diameter.

Remarks. - The citation of this genus and species used in the literature is actually incorrect: Prophyllodictya intermedia Gorjunova, 1987 (see Gorjunova \& Lavrentjeva 1993; Gorjunova 1996). There is no publication Gorjunova (1987). The genus and species were published in the mutual paper of Gorjunova \& Lavrentjeva (1987), even if authored by Gorjunova alone.
Prophyllodictya intermedia Gorjunova, 1987 in Gorjunova \& Lavrentjeva (1987) is similar to P. putilovensis Lavrentjeva, 1993 in Gorjunova \& Lavrentjeva (1993) but differs from the latter in having widely spaced autozooecial apertures $(c a .2$ per $2 \mathrm{~mm}$ distance along the branch vs. 4-5 in P. putilovensis).

Occurrence. - Floian, Lower Ordovician of Russia and Estonia. Obukhovo Fm., Kunda Stage, Darriwilian, Middle Ordovician; Putilovo quarry, Russia (present material).

\section{Cryptostomata sp. indet.}

Figure 17D-I, 18A-F; Table 16

Material. - Single specimen GIT 537-4098a (one thin section).

Table 16. Descriptive statistics of Cryptostomata sp. indet. (one colony measured). Abbreviations as for Table 1.

\begin{tabular}{lcccccc}
\hline & $\mathrm{N}$ & MIN & MAX & X & SD & CV \\
\hline $\begin{array}{l}\text { Aperture width, mm } \\
\text { Aperture spacing along }\end{array}$ & 20 & 0.11 & 0.20 & 0.15 & 0.025 & 16.61 \\
branch, mm & 20 & 0.47 & 0.75 & 0.62 & 0.091 & 14.78 \\
Aperture spacing diagonally, mm & 20 & 0.28 & 0.45 & 0.38 & 0.054 & 14.29 \\
Vesicle diameter, mm & 10 & 0.05 & 0.11 & 0.07 & 0.017 & 23.14 \\
\hline
\end{tabular}

Description. - Reticulate colony composed of flat bifoliate branches anastomosing at regular intervals. Branches $3.3-3.8 \mathrm{~mm}$ wide. Fenestrules circular to oval, $2.3-2.5 \mathrm{~mm}$ wide and $2.7-3.6 \mathrm{~mm}$ long. Autozooecia arranged in 8-10 alternating rows on branches, short, polygonal in mid tangential section. Long distally curved hemisepta dividing autozooecial chamber present (Fig. 18D-F). Autozooecial apertures circular to oval. Paurostyles in outer laminated skeleton, arranged in 1-2 rows on low crests around autozooecial apertures, forming polygonal pattern on colony surface, $0.02-0.03 \mathrm{~mm}$ in diameter (Fig. $17 \mathrm{G}-\mathrm{I}$ ). Autozooecial wall in endozone $0.005-0.010 \mathrm{~mm}$ thick. Polygonal vesicles at the base of exozone present, covered by laminated skeleton. Maculae not observed.

Remarks. - The present specimen shows a unique morphology which does not allow any assignment: polygonal autozooecial chambers and rounded apertures, long curved hemisepta, vesicles and paurostyles. It resembles superficially the genus Trepocryptopora Yang, 1957 from the Lower Ordovician of China. However, the latter genus has no hemisepta and paurostyles, it possesses frondose colony instead of reticulate one in the present material. Furthermore, Trepocryptopora possesses open heterozooecia different to the vesicles of the present material, which are covered by laminated skeleton. The 

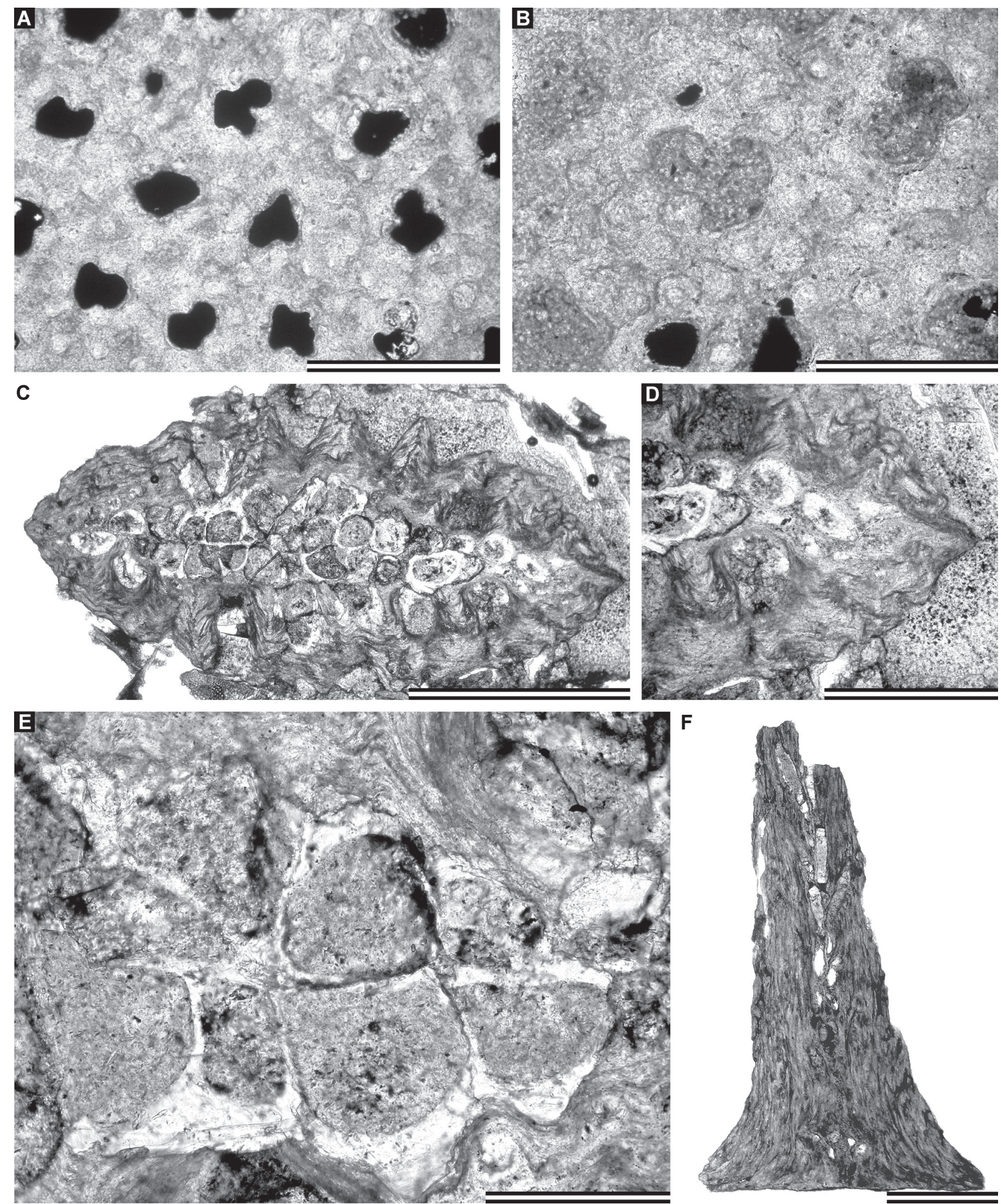

Figure 16. A-B - Pakripora cavernosa gen. et sp. nov., tangential section showing autozooecial apertures, acanthostyles, and mesozooecia in intermacular area, holotype GIT 537-2265g. • C-F - Prophyllodictya intermedia Gorjunova, 1987 in Gorjunova \& Lavrentjeva (1987); C-E - branch transverse section, GIT 852-4a; F - longitudinal section through the basal part of the colony, GIT 852-8a. Scale bars: $1 \mathrm{~mm}(\mathrm{C}, \mathrm{F}), 0.5 \mathrm{~mm}(\mathrm{~A}, \mathrm{D})$, $0.2 \mathrm{~mm}(\mathrm{~B}, \mathrm{E})$. 

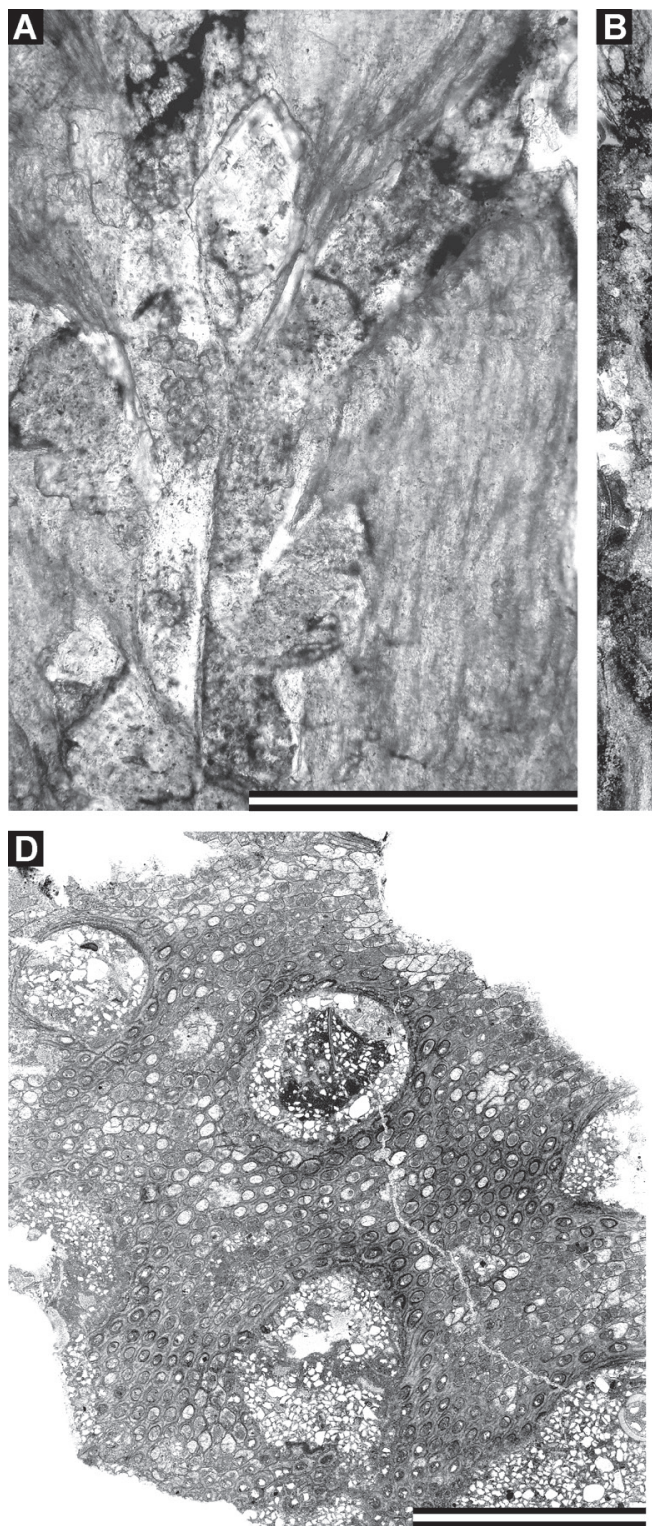
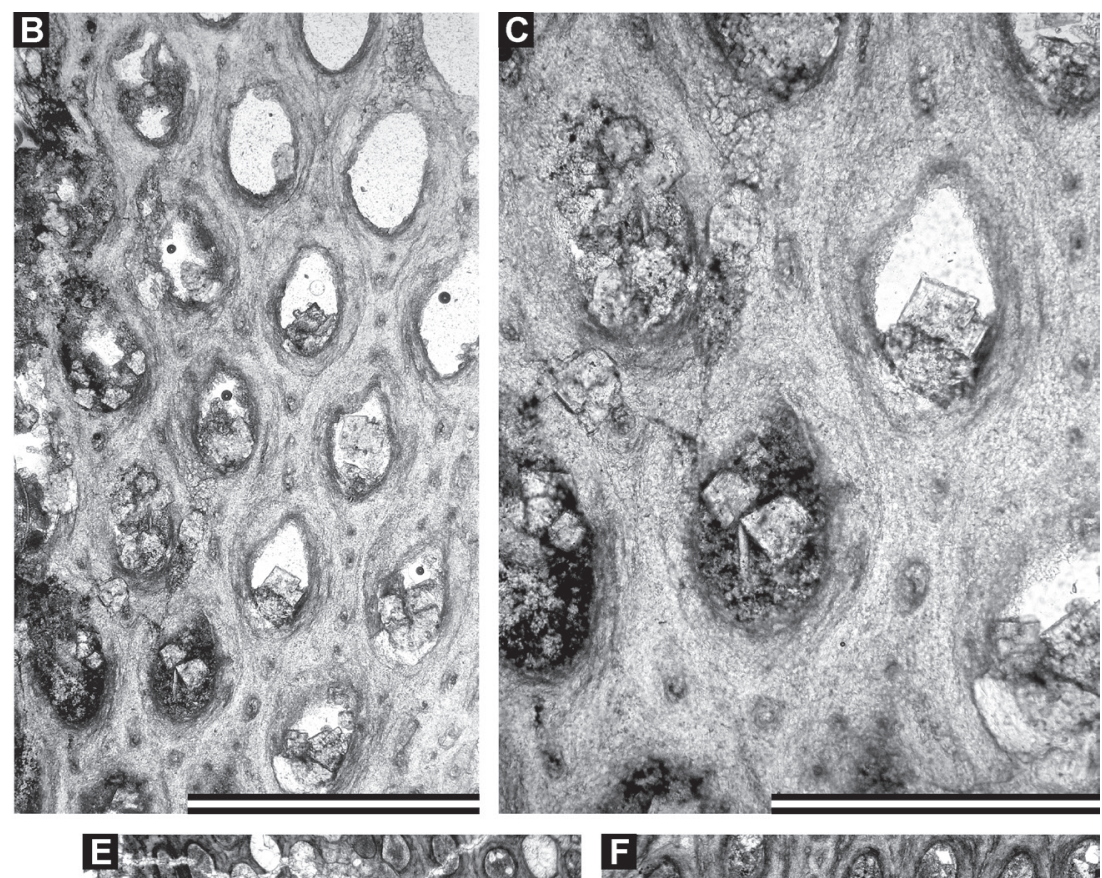

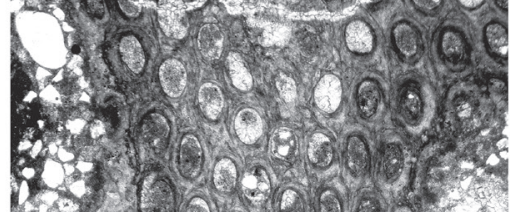
802000
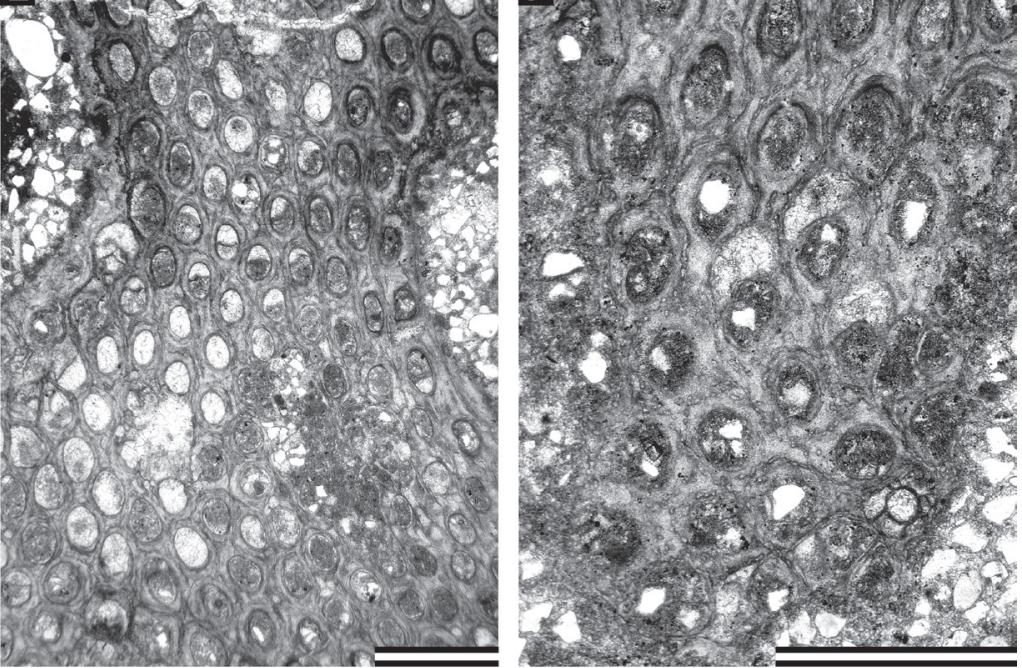
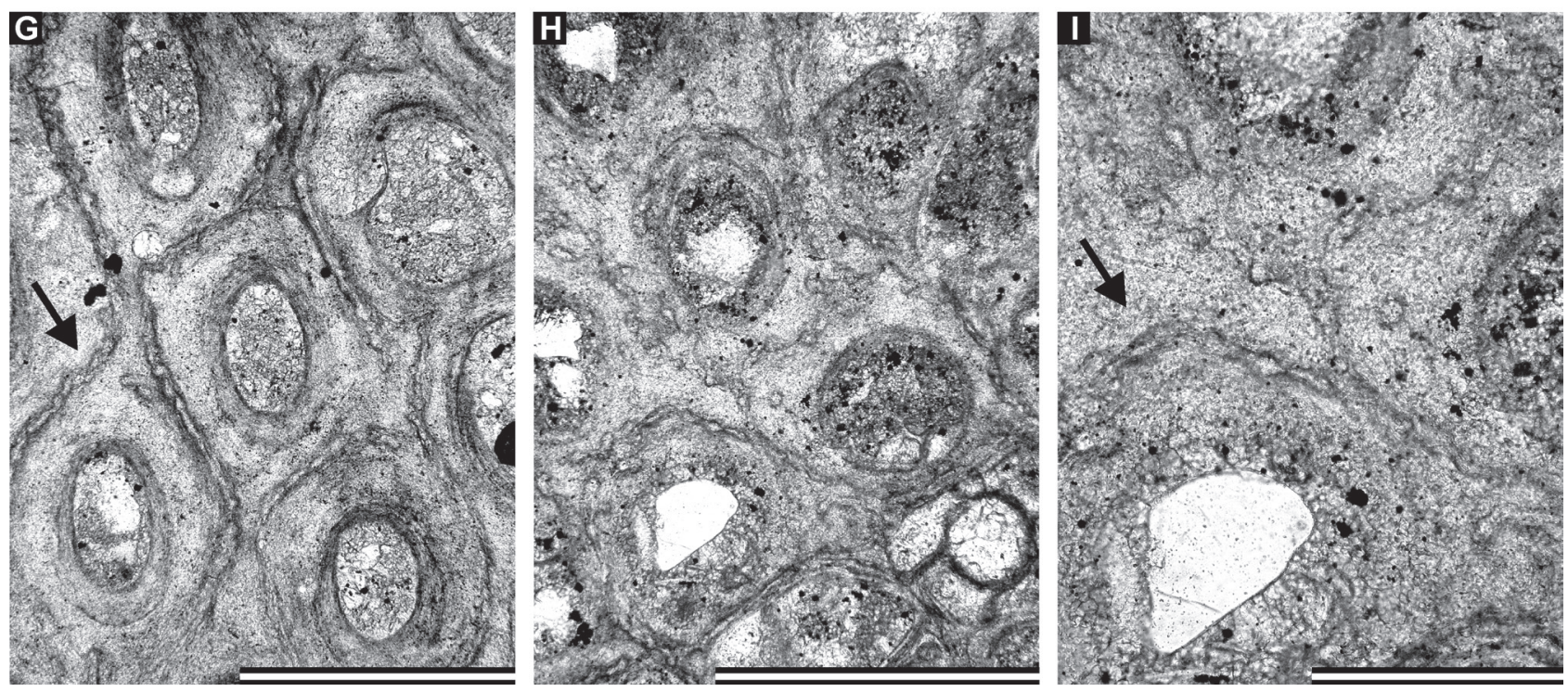

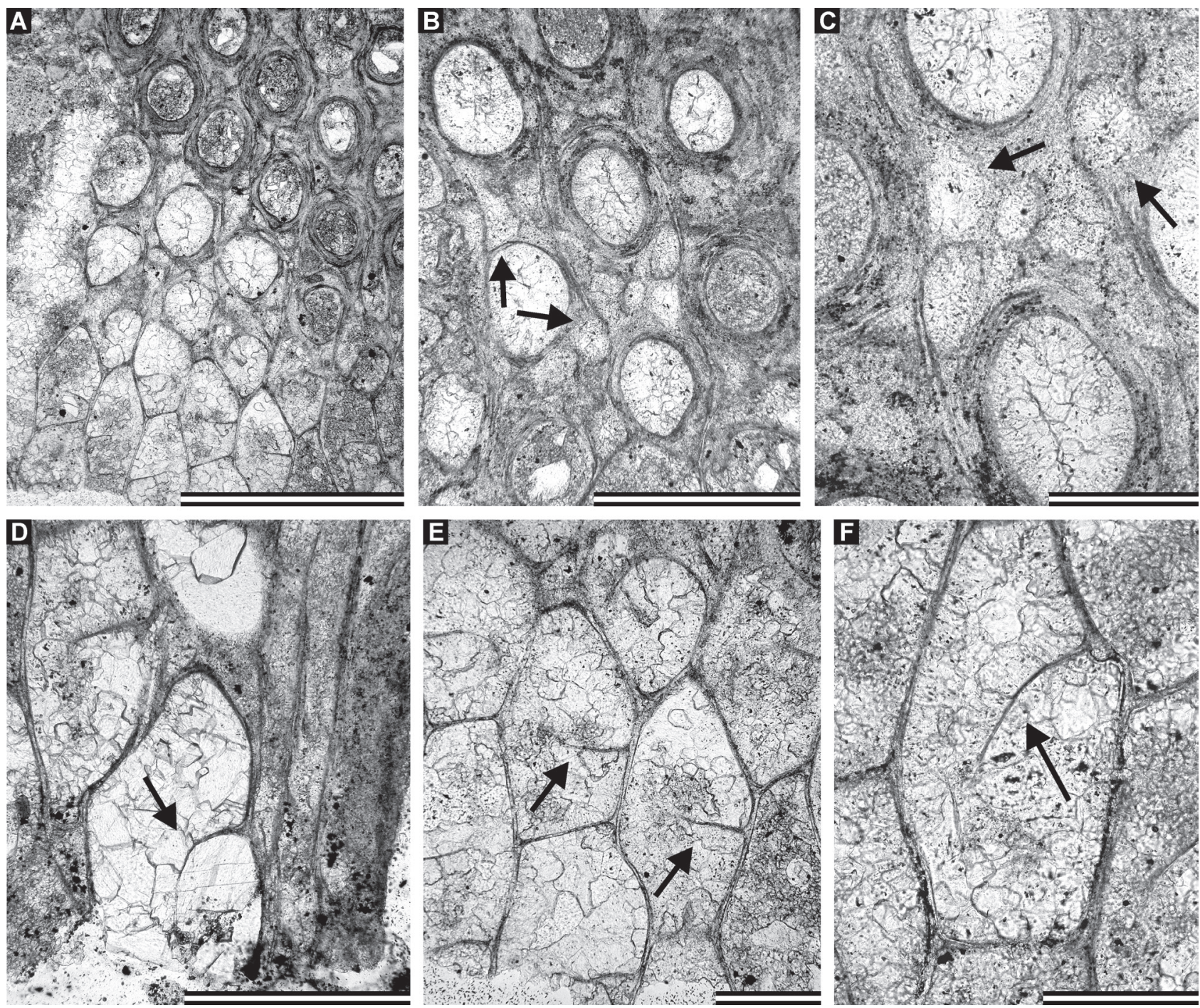

Figure 18. A-F - Cryptostomata sp. indet., GIT 537-4098a; A-C - tangential section showing autozooecial apertures and vesicles (arrows); D-F - mid tangential section showing autozooecial chambers with hemisepta (arrows). Scale bars: $1 \mathrm{~mm}(\mathrm{~A}), 0.5 \mathrm{~mm}(\mathrm{~B}, \mathrm{D}), 0.2 \mathrm{~mm}(\mathrm{C}, \mathrm{E}, \mathrm{F})$.

present material shows some similarity to the genus Phyllodictya Ulrich, 1882 in presence and character of styles and in presence of vesicular skeleton. However, Phyllodictya has no long curved hemisepta and its autozooecial chambers are oval in mid tangential section. The genus Sibiredictya Nekhoroshev, 1961 is similar in the colony shape, presence of styles and vesicular skeleton, but differs in absence of hemisepta.

Occurrence. - Kunda Stage, Darriwilian, Middle Ordovician; Paldiski, Estonia.

\section{Discussion and conlusion}

Described bryozoan fauna from the Kunda Stage (Darriwilian, Middle Ordovician) of Estonian and NW Russia contains 18 species which includes one cystoporate Ceramopora cf. magnicellularis Männil \& Pushkin in Pushkin, 1990, eight esthonioporates Dianulites collucatus Pushkin, 2001 in Pushkin \& Popov (2001), D. pakriensis sp. nov., Esthoniopora communis Bassler, 1911, Revalotrypa gibbosa (Bassler, 1911), R. papillaris (Modzalevskaya, 1953), Orbipora indenta Bassler, 1911,

Figure 17. A-C - Prophyllodictya intermedia Gorjunova, 1987 in Gorjunova \& Lavrentjeva (1987), GIT 852-4b; A - longitudinal section; B, C tangential section showing autozooecial apertures and paurostyles. - D-I - Cryptostomata sp. indet., GIT 537-4098a; D - tangential section showing colony shape with oval fenestrules; E-I - tangential section showing autozooecial apertures, paurostyles and crests around autozooecial apertures (arrows). Scale bars: $5 \mathrm{~mm}$ (D), $1 \mathrm{~mm}$ (B, E, F), $0.5 \mathrm{~mm}$ (A, C, G, H), $0.2 \mathrm{~mm}$ (I). 
O. acanthophora Bassler, 1911, and O. aff. distincta (Eichwald, 1829); six trepostomes Dittopora sokolovi Modzalevskaya, 1953, D. annulata (Eichwald, 1860), D. aff. annulata (Eichwald, 1860), Hemiphragma rotundatum Bassler, 1911, Mesotrypa bystrovi Modzalevskaya, 1953, Sonninopora sp., and Pakripora cavernosa gen. nov., sp. nov.; and two cryptostomes Prophyllodictya intermedia Gorjunova, 1987 in Gorjunova \& Lavrentjeva (1987) and Cryptostomata sp. indet.

This species composition is quite endemic within the Baltic region. Genera Esthoniopora Bassler, 1911, Orbipora Eichwald, 1856 and Dittopora Dybowski, 1877 are mainly restricted to the Baltosandian region, whereas Revalotrypa Bassler, 1952 and Prophyllodictya Gorjunova, 1987 in Gorjunova \& Lavrentjeva (1987) are also known from the Lower Ordovician of China (Yang 1957, Xia et al. 2007, Ma et al. 2015). Genera Ceramopora Hall, 1851 in Silliman, Silliman \& Dana (1851), Hemiphragma Ulrich, 1893 and Mesotrypa Ulrich, 1893 show cosmopolitan distribution during the Middle Ordovician.

The studied fauna shows moderate diversity of colony forms: massive, branched ramose, rod-(club-) shaped, and lenticular (frondose and reticulate).

Massive colonies of various configuration are developed by nine species. They are mainly composed of subsequently overgrown encrusting sheets (Ceramopora cf. magnicellularis, Dianulites collucatus, Esthoniopora communis, Revalotrypa gibbosa, Orbipora indenta, O. acanthophora, Hemiphragma rotundatum). Forming of subcolonies is usual in Ceramopora cf. magnicellularis, Dianulites collucatus, and Revalotrypa gibbosa (Fig. 6B). Mesotrypa bystrovi is the only massive species which shows neither secondary overgrowths nor subcolonies (Fig. 13D). The species $O$. aff. distincta (Eichwald, 1829) is represented by small hemispheric colony which lacks any overgrowth, apparently due to its small size (Fig. 8F).

Revalotrypa papillaris has a unique colony which is rod- or club-shaped (Fig. 6G, H).

Dittopora species are all ramose, quite robust, with branch diameters ranging from 1.95 to $4.9 \mathrm{~mm}$. The species Dianulites pakriensis and Pakripora cavernosa have both robust branched colonies (with branch diameters $19-28 \mathrm{~mm}$ in Dianulites pakriensis and $11.5-17.0 \mathrm{~mm}$ in Pakripora cavernosa). Secondary overgrowths are usual in the branched species.

The single specimen of Sonninopora sp. shows apparently branched colony as well. However, the true configuration of that colony is not clear in the present material (Fig. 14A).

Both cryptostomes (ptilodictyine) species are lenticular, with zooecia budding from the median lamina called mesotheca (Fig. 16C-E). Whereas Prophyllodictya intermedia possesses frondose colonies, the single specimen of Cryptostomata sp. indet. represents reticulate colony with large oval fenestrules (Fig. 17D). Mesotheca is not seen in this specimen, however, as far as only tangential section is available.

Several species developed special structures called maculae. Those are areas on the colony surface differently composed as the rest of the colony. They are often composed of heterozooecia (e.g. Dianulites pakriensis, Fig. 5A, B), or heterozooecia and acanthostyles (e.g. Dittopora aff. annulata, Fig. 12E, or Pakripora cavernosa, Fig. 15G, H). Maculae can be positioned on the level of the colony surface, but usually they are either depressed or elevated. In the last case they are called monticulae. These structures serve mainly as sites of excurrent chimneys, with which the filtered water is expelled from the colony surface (e.g. Banta et al. 1974; Taylor 1975, 1979, 1999; Cook 1977; Winston 1978, 1979; Lidgard 1981). In Dittopora annulata and D. aff. annulata the maculae are transversally annular and depressed below the colony surface, whereas they are rounded and slightly elevated above the colony surface in Pakripora cavernosa. According to observations on modern bryozoans, large maculate species are able to determine their own water flow relatively independent from ambient conditions (e.g. Schopf et al. 1980). Development of maculae is regarded being an important adaption in bryozoan evolution (e.g. McKinney 1986, McKinney \& Jackson 1989).

The dominance of massive (9) and erect (9) species as well as absence of encrusting bryozoans suggest rather middle shelf conditions, with moderate to low water energy and quite high sedimentation rates (e.g. Nelson et al. 1988, Hageman et al. 1997, Amini et al. 2004). Similar setting for the distribution of massive bryozoan colonies was observed in the Ordovician of Öland (Spjeldnaes 1996) or Silurian of Gotland (Brood 1984). Development of subcolonies and secondary overgrows point to the episodic sedimentation stops (e.g. Spjeldnaes 1996).

In addition, bryozoan colonies from the studied fauna often contain traces of bioerosion and bioclaustration. They mainly belong to Trypanites (Figs 3A; 13D, E), some others cannot be identified with certainty (Olev Vinn, personal communication 2021). Unknown bioclaustration is observed in the colony of Orbipora acanthophora (Fig. 7G).

\section{Acknowledgements}

Deutsche Forschungsgemeinschaft (DFG) is appreciated for financial support (project ER 278/10.1). Ursula Toom, Tallinn, is thanked for help with the material housed at the Department of Geology, Tallinn University of Technology (GIT) as well as assistance in the field. Olev Vinn, Tartu, is appreciated for his identification of bioerosion in bryozoan colonies. Ernest 
H. Gilmour, Washington, and Caroline Buttler, Cardiff are thanked for their helpful and constructive reviews. This paper is a contribution to the IGCP 653 "The onset of the Great Ordovician Biodiversification Event".

\section{References}

Amini, Z.Z., Adabi, M.H., Burrett, C.F. \& Quilty, P.G. 2004. Bryozoan distribution and growth form associations as a tool in environmental interpretation, Tasmania, Australia. Sedimentary Geology 167(1-2), 1-15.

DOI 10.1016/j.sedgeo.2004.01.010

Anstey, R.L. \& Perry, T.G. 1970. Biometric procedures in taxonomic studies of Paleozoic bryozoans. Journal of Paleontology 44, 383-398.

Astrova, G.G. 1964. A new order of the Paleozoic Bryozoa. Paleontologicheskiy Zhurnal 1964(2), 22-31. [in Russian]

Astrova, G.G. 1965. Morphology, history of development and system of the Ordovician and Silurian Bryozoa. Trudy Paleontologicheskogo Instituta 106, 1-432. [in Russian]

Astrova, G.G. 1978. The history of development, system, and phylogeny of the Bryozoa: Order Trepostomata. Trudy Paleontologicheskogo Instituta 169, 1-240. [in Russian]

Astrova, G.G. \& Morozova, I.P. 1956. On systematics of the bryozoans of the Order Cryptostomata. Doklady Akademii Nauk SSSR 110(4), 661-664. [in Russian]

Banta, W.C., McKinney, F.K. \& Zimmer, R.L. 1974. Bryozoan monticules: excurrent water outlets? Science 185, 783-784. DOI 10.1126/science.185.4153.783

Bassler, R.S. 1911. The early Paleozoic Bryozoa of the Baltic Provinces. Bulletin of the Smithsonian Institution, United States National Museum 77, 1-382.

Bassler, R.S. 1913. Bryozoa, 314-355. In Zittel, K.A. \& EASTMAN, C.R (eds) Text-book of Paleontology, Vol. 1. Macmillan \& Co., London.

BASSLER, R.S. 1936. Nomenclatorial notes on fossil and Recent Bryozoa. Journal of the Washington Academy of Science 26, $156-162$.

BASSLER, R.S. 1952. Taxonomic notes on genera of fossil and Recent Bryozoa. Journal of the Washington Academy of Sciences 42, 381-385.

Borg, F. 1926. Studies on Recent cyclostomatous Bryozoa. Zoologiska Bidrag från Uppsala 10, 181-507.

Brood, K. 1984. Bryozoan ecology in the Silurian of Gotland. Special Papers in Palaeontology 32, 211-224. DOI 10.1016/0031-0182(76)90002-X

Buttler, C. \& MAssa, D. 1996. Late Ordovician bryozoans from carbonate buildups, Tripolitania, Libya, 63-68. In Gordon, D.P., Smith, A.M. \& Grant-Mackie, J.A. (eds) Bryozoans in Space and Time. Proceedings of the $10^{\text {th }}$ International Bryozology Conference, Wellington, New Zealand, 1995. National Institute of Water and Atmospheric Research Ltd, Wellington.

Buttler, C., Cherns, L. \& Massa, D. 2007. Bryozoan mudmounds from the Upper Ordovician Jifarah (Djeffara) For- mation of Tripolitania, north-west Libya. Palaeontology 50(2), 479-494. DOI 10.1111/j.1475-4983.2007.00636.x

Cocks, R.L.M. \& Torsvik, T.H. 2005. Baltica from the late Precambrian to mid-Palaeozoic times: the gain and loss of a terrane's identity. Earth-Science Reviews 72, 39-66. DOI 10.1016/j.earscirev.2005.04.001

Conti, S. \& Serpagli, E. 1987. Functional morphology of the cap-like apparatus in autozooids of a Palaeozoic trepostome bryozoan. Lethaia 20, 1-20. DOI 10.1111/j.1502-3931.1987.tb00754.x

CooK, P.L. 1977. Colony-wide water currents in living Bryozoa. Cahiers de Biologie Marine 18, 31-47.

DANA, J.D. 1846. Zoophytes. United States Exploring Expedition 7, 1-740. DOI 10.5962/bhl.title.70845

Dronov, A. \& Rozhnov, S. 2007. Climatic changes in the Baltoscandian basin during the Ordovician: sedimentological and palaeontological aspects. Acta Geologica Sinica 46, 108-113.

Dyвowski, W. 1877. Die Chaetetiden der ostbaltischen SilurFormation. Russische Kaiserliche Mineralogische Gesellschaft zu St. Petersburg, Verhandlungen, Series 2(14), 1-134.

Ehrenberg, C.G. 1831. Symbolae Physicae, seu Icones et descptiones Corporum Naturalium novorum aut minus cognitorum, quae ex itineribus per Libyam, Aegiptum, Nubiam, Dongalaam, Syriam, Arabiam et Habessiniam, studia annis 1820-25, redirent. Pars Zoologica, 4, Animalia Evertebrata exclusis Insectis. 10 pls. Berolini.

EICHWALd, E. 1829. Zoologia specialis quam expositis animalibus tum vivis, fom fossilibus potissimum Rossiae in universum, et Poloniae in specie, vol. 1. Bryozoa. 314 pp. Typis Josephi Zawadzki, Vilnae. DOI 10.5962/bhl.title.51803

EICHWALD, E. 1856. Beitrag zur geographischen Verbreitung der fossil Thiere Russlands. Bulletin de la Société des Naturelles de Moscovian 29, 91-96, 448-466.

Eichwald, E. 1860. Lethaea Rossica, ou Paléontologie de la Russie. I. Ancienne Periode. 1657 pp. Schweizerbart, Stuttgart.

ERnst, A. 2018. Diversity dynamics of Ordovician Bryozoa. Lethaia 51, 198-206. DOI 10.1111/let.12235

ERnst, A. \& NAKrem, H.A. 2011. Stenolaemate bryozoans from the Mjøsa Formation (Late Ordovician, Katian) of Helgøya (Bergevika), southern Norway. Norwegian Journal of Geology 91, 163-180.

ERnst, A. \& NAKRem, H.A. 2012. Late Ordovician (Sandbian) bryozoans and their depositional environment, Furuberget Formation, Mjøsa District, Oslo Region, Norway. Bulletin of Geosciences 87(1), 21-44. DOI 10.3140/bull.geosci.1316

Fedorov, P.V., Koromyslova, A.V. \& Martha, S.O. 2017. The oldest bryozoans of Baltoscandia from the lowermost Floian (Ordovician) of north-western Russia: two new rare, small and simple species of Revalotrypidae. Paläontologische Zeitschrift 91(3), 353-363. DOI 10.1007/s12542-017-0351-y

GorJunova, R.V. 1988. On the systematic position of the genus Revalotrypa. Paleontologicheskii Zhurnal 1988(2), 31-36. [in Russian]

Gorjunova, R.V. 1996. Phylogeny of the Paleozoic Bryozoa. Trudy Paleontologischeskogo Instituta 267, 1-161. 
GorJunova, R.V. 2005. Ralfimartitidae, a new family of Paleozoic bryozoans of the order Trepostomida. Paleontologicheskii Zhurnal 2, 51-63. [in Russian]

GorJunOva, R.V. 2009. Evolution of the colonial growth habit in the Ordovician bryozoans of the Class Stenolaemata: feeding adaptation (Leningrad Region, Russia). Paleontologicheskii Zhurnal 43 (Supplement 11), 1390-1408. DOI 10.1134/S0031030109110045

Gorjunova, R.V. \& Koromyslova, A.V. 2008. A new genus of the Arenigian bryozoans, Lynnopora, and its systematic position in the family Revalotrypidae Gorjunova, 1988. Paleontological Journal 42(5), 491-499. DOI 10.1134/S0031030108050043

Gorjunova, R.V. \& Lavrentjeva, V.D. 1987. New genus Prophyllodictya, and the most ancient representative of cryptostome Bryozoa. Paleontologicheskii Zhurnal 1987(1), 41-51. [in Russian]

Gorjunova, R.V. \& Lavrentueva, V.D. 1993. Morphology and system of the cryptostome bryozoans. Trudy Paleontologischeskogo Instituta 257, 1-150. [in Russian]

Hageman, S.J. 1993. Effects of nonnormality on studies of the morphological variation of a rhabdomesine bryozoan, Streblotrypa (Streblascopora) prisca (Gabb and Horn). The University of Kansas Paleontological Contributions 4, 1-13. DOI 10.17161/PCNS.1808.3767

Hageman, S.J., Bone, Y., McGowran, B. \& James, N.P. 1997. Bryozoan colonial growth forms as paleoenvironmental indicators: Evaluation of methodology. Palaios 12, 406-419. DOI $10.2307 / 3515380$

Hall, J. 1852. Palaeontology of New York, Volume 2, Organic Remains of the Lower Middle Division of the New York System. New York Geological Survey, Natural History of New York v. 6, 40-52, 144-173.

Hansen, T., Nielsen, A.T. \& Bruton, D.L. 2011. Palaeoecology in a mud-dominated epicontinental sea: A case study of the Ordovician Elnes Formation, southern Norway. Palaeogeography, Palaeoclimatology, Palaeoecology 299, 348-362. DOI 10.1016/j.palaeo.2010.11.014

Hints, O., Ainsaar, L., Männik, P. \& Meidla, T. (eds) 2008. The Seventh Baltic Stratigraphical Conference. Abstracts and Field Guide. 46 pp. Geological Society of Estonia, Tallinn.

Kaljo, D. \& Nestor, H. 1990. Field meeting Estonia, 1990: An Excursion Guidebook. 209 pp. Institute of Geology, Estonian Academy of Sciences, Tallinn.

KeY, M.M., JR 1990. A new family of trepostome bryozoans from the Ordovician Simpson Group of Oklahoma. Journal of Paleontology 64, 700-724. DOI 10.1017/S002233600001893X

KeY, M.M., JR \& JudD, A.B. 1994. Phylogenetic relationships of the Middle Ordovician trepostome bryozoans Sonninopora and Bimuropora. Journal of Paleontology 68, 241-257. DOI 10.1017/S0022336000022836

Koromyslova, A.V. 2004. Bryozoans of the Genus Diplotrypa Nicholson, 1879 from the Middle Ordovician of the Leningrad Region. Paleontologicheskii Zhurnal 2004(6), 47-49. [in Russian]
Koromyslova, A.V. 2007. Morphogenesis, phylogenetic relationships, and distribution of the bryozoans of the genus Orbipora Eichwald, 1856 (Order Trepostomida). Paleontological Journal 41(2), 132-145. [in Russian]

DOI 10.1134/S0031030107020049

Koromyslova, A.V. 2011. Bryozoans of the Latorp and Volkhov Horizons (Lower-Middle Ordovician) of the Leningrad Region. Paleontological Journal 45(8), 887-980.

DOI 10.1134/S0031030111080028

Koromyslova, A. \& Fedorov, P. 2021. The oldest bifoliate cystoporate and two other bryozoan taxa from the Dapingian (Middle Ordovician) of north-western Russia. Journal of Paleontology 95(1), 24-39. DO 10.1017/jpa.2020.73

LavrentJeVA, V.D. 1975. A new bryozoan genus of the family Phylloporinidae. Paleontologicheskii Zhurnal 1975(4), 138-140. [in Russian]

Lavrentjeva, V.D. 1985. Bryozoans of the sub-order Phylloporinida. Trudy Paleontologicheskogo Instituta 214, 1-100. [in Russian]

LidgARD, S. 1981. Water flow, feeding, and colony form in an encrusting cheilostome, 135-142. In LARWOOD, G.P. \& Nielsen, C. (eds) Recent and Fossil Bryozoa. Olsen \& Olsen, Fredensborg.

MA, J.-Y., Buttler, C.J. \& TAYLOR, P.D. 2014. Cladistic analysis of the 'trepostome' Suborder Esthonioporina and the systematics of Palaeozoic bryozoans, 153-161. In Rosso, A., Wyse Jackson, P.N. \& Porter, J.S. (eds) Bryozoan Studies 2013. Studi Trentini di Scienze Naturali 94.

MA, J., TAYloR, P.D., XIA, F. \& Zhan, R. 2015. The oldest known bryozoan: Prophyllodictya (Cryptostomata) from the lower Tremadocian (Lower Ordovician) of Liujiachang, southwestern Hubei, central China. Palaeontology 58(5), 925-934. DOI 10.1111/pala.12189

MäNNIL, R.M. 1958. New bryozoans of the order Cryptostomata from Ordovician of Estonia. Eesti NSV Teaduste Akadeemia Toimetised, Tehniliste ja füüsikalis-matemaatiliste teaduste seeria 7(4), 330-347. [in Russian]

DOI 10.3176/tech.phys.math.1958.4.07

MäNNIL, R.M. 1959. Questions of stratigraphy and bryozoans of the Ordovician of Estonia. 636 pp. Ph.D. thesis, Institut Geologii Akademii Nauk Estonskoi SSR, Tallinn, Estonia. [in Russian]

McKinney, F.K. 1971. Trepostomatous Ectoprocta (Bryozoa) from the lower Chickamauga Group (Middle Ordovician), Wills Valley, Alabama. Bulletins of American Paleontology 60, 195-333.

McKinNEY, F.K. 1986. Evolution of erect marine bryozoan faunas: repeated success of unilaminate species. The American Naturalist 128, 795-809.

DOI 10.1086/284606

McKinney, F.K. \& JACKson, J.B.C. 1989. Bryozoan Evolution. Studies in Paleobiology. 238 pp. Unwin Hyman, Boston.

Meidla, T. 1997. Kunda Stage, 64-66. In Raukas, A. \& Teedumäe, A. (eds) Geology and Mineral Resources of Estonia. Estonian Academy Publishers, Tallinn.

Modzalevskaya, E.A. 1953. Trepostomata of the Ordovician of East Baltic and their stratgraphic significance. Trudy 
Vsesojuznogo Nauchnoissledovatelskogo Geologo-Razvedochnogo Instituta (VNIGRI) 78, 91-167. [in Russian]

Modzalevskaya, E.A. 1986. Bryozoa of the family Dittoporidae from the Ordovician of the Leningrad District. Ezhegodnik Vsesojuznogo Paleontologicheskogo Obtchestva 29, 74-91. [in Russian]

Nekhoroshev, V.P. 1961. Ordovician and Silurian bryozoans of Siberian Plate. Trudy VSEGEI, New Series 41, 1-246. [in Russian]

Nelson, C.S., Hyden, F.M., Keane, S.L., Leask, W.L. \& Gordon, D.P. 1988. Application of bryozoan zoarial growth-form studies in facies analysis of non-tropical carbonate deposits in New Zealand. Sedimentary Geology 60, 301-322. DOI 10.1016/0037-0738(88)90126-1

Nõlvak, J., Hints, O. \& Männik, P. 2006. Ordovician timescale in Estonia: recent developments. Proceedings of the Estonian Academy of Sciences, Geology 55(2), 95-108. DOI 10.3176/geol.2006.2.02

Pushkin, V.I. 1976. New species of Ordovician and Silurian Bryozoa of the Brest Depression, 3-40. In AkImETs, V.S. \& GovetskiI, G.I. (eds) New species of the fossil plants and animals of Belarus. Nauka i Tekhnika, Minsk. [in Russian]

PushkIn, V.I. 1977. About systematic position and the composition of the genus Dittopora (Bryozoa). Transactions of the museum of earth-study of Moscow University 12, 97-113. [in Russian]

Pushkin, V.I. 1987. Bryozoans of suborder Halloporina from Belorussia and East European Platform, 145-232. In Rорот, V.P. \& Pushrin, V.I. (eds) Ordovician of Belarus. Nauka i Tekhnika, Minsk. [in Russian]

Pushkin, V.I. 1990. Bryozoa of the family Ceramoporidae of Ordovician from the eastern European platform, 5-34. In New representatives of the fossil fauna and flora of Belorussia and other regions of the USSR: collected scientific papers. Nauka i Tekhnika, Minsk. [in Russian]

Pushinin, V.I. 2002. Middle Ordovician Bryozoa from the Podlasie-Brest Depression (Belarussian part); suborders Ceramoporina, Esthonioporina, Amplexoporina, Halloporina. Geological Quarterly 46(4), 411-434.

Pushrin, V.I. \& Popov, L.E. 2001. The Dianulites genus (Bryozoa, Trepostomida) in the Arenig and Llanvirn of the East European Platform. Lithosphere (Litasfera, Belarus) 15, 12-31.

Ross, J.R.P. 1970. Distribution, paleoecology, and correlation of Champlainian Ectoprocta (Bryozoa), New York State, Part III. Journal of Paleontology 44, 346-382.

Schopf, T.J.M., Collier, K.O. \& BACH, B.O. 1980. Relation of the morphology of stick-like bryozoans at Friday Harbour, Washington, to bottom currents, suspended matter and depth. Paleobiology 6, 466-476. DOI 10.1017/S0094837300003638

Silliman, B., Silliman, B., JR \& Dana, J.D. 1851. New genera of fossil corals from the report of James Hall, on the palaeontology of New York. American Journal of Sciences and Arts 2, 398-401.

Smith, A.M., Key, M.M., JR \& Gordon, D.P. 2006. Skeletal mineralogy of bryozoans: taxonomic and temporal patterns. Earth Science Reviews 78(3-4), 287-306.

DOI 10.1016/j.earscirev.2006.06.001
SpJeldnAEs, N. 1996. Bryozoan colonies as indicators of bottom conditions in the lower Ordovician, 315-320. In Gordon, D.P., Smith, A.M. \& Grant-Mackie, J.A. (eds) Bryozoans in Space and Time. Proceedings of the 10th International Bryozology Conference, Wellington, New Zealand, 1995. National Institute of Water and Atmospheric Research Ltd, Wellington.

TAVENER-Smith, R. 1969. Wall structures and acanthopores in the bryozoan Leioclema asperum. Lethaia 2, 89-97. DOI 10.1111/j.1502-3931.1969.tb01629.x

TAYLOR, P.D. 1975. Monticules in Jurassic cyclostomatous bryozoan. Geological Magazine 112, 601-606. DOI 10.1017/S0016756800039017

TAYLOR, P.D. 1979. The inference of extrazooidal feeding currents in fossil bryozoan colonies. Lethaia 12, 47-56. DOI 10.1111/j.1502-3931.1979.tb01241.x

TAYlor, P.D. 1999. Bryozoans, 623-645. In SAvazzi, E. (ed.) Functional morphology of the invertebrate skeleton. Wiley, New York.

TAYLOR, P.D. \& Wilson, M.A. 1999. Dianulites Eichwald, 1829: an unusual Ordovician bryozoan with a high-magnesium calcite skeleton. Journal of Paleontology 73, 38-48. DOI 10.1017/S0022336000027529

Torsvik, T. \& Cocks, L. 2016. Earth History and Palaeogeography. 332 pp. Cambridge University Press, Cambridge. DOI 10.1017/9781316225523

ULrich, E.O. 1882. American Palaeozoic Bryozoa. The Journal of the Cincinnati Society of Natural History 5, 121-175, 233-257.

UlRiCH, E.O. 1886. Descriptions of new Silurian and Devonian fossils. Bryozoa. Contributions to American Palaeontology 1, 8-33. DOI 10.5962/bhl.title.140012

Ulrich, E.O. 1890. Palaeozoic Bryozoa: III. Report of the Geological Survey of Illinois 8, 283-688.

UlRiCh, E.O. 1893. On Lower Silurian Bryozoa of Minnesota. The Geological and Natural History Survey of Minnesota, final report 3, 96-332. DOI 10.5962/bhl.title.56338

UtgaARd, J. 1968. A revision of North American genera of ceramoporoid bryozoans (Ectoprocta): Part II; Crepipora, Ceramoporella, Acanthoceramoporella, and Ceramophylla. Journal of Paleontology 42, 1444-1455.

UtgaARd, J. 1983. Systematic descriptions for the Order Cystoporata, 357-439. In Robison, R.A. (ed.) Treatise on Invertebrate Paleontology, Part G (1): Bryozoa (revised). Geological Society of America and University of Kansas Press, Boulder.

Vinassa de Regny, P. 1921. Sulla classificazione dei trepostomidi. Societa Italiana di Sceinze Naturali Atti 59, 212-231.

VINE, G.R. 1884. Fourth report of the Committee appointed for the purpose of reporting on fossil Polyzoa. Reports of the $53^{\text {rd }}$ meeting of the British Association for Advances in Science, 161-209.

Winston, J.E. 1978. Polypide morphology and feeding in marine ectoprocts. Bulletin of Marine Science 28, 1-31.

Winston, J.E. 1979. Current-related morphology and behaviour 
in some Pacific coast bryozoans, 247-268. In LARWOOD, G.P. \& Аввотт, M.B. (eds) Advances in Bryozoology. Academic Press, London.

XIA, F., Zhang, S. \& Wang, Z. 2007. The oldest bryozoans: new evidence from the Late Tremadocian (Early Ordovician) of East Yangtze Gorges in China. Journal of Paleontology 81(6), 1308-1326. DOI 10.1666/04-128.1

YANG, J. 1957. Some Bryozoa from the upper part of the Lower Ordovician of Liangshan, southern Shensi (including a new genus). Acta Paleontologica Sinica 5, 1-10. 